\author{
UNIVERSIDADE DE SÃO PAULO \\ FACULDADE DE FILOSOFIA, LETRAS E CIÊNCIAS HUMANAS \\ DEPARTAMENTO DE GEOGRAFIA \\ PROGRAMA DE PÓS-GRADUAÇÃO EM GEOGRAFIA HUMANA
}

O PROCESSO DE DESFAVELIZAÇÃO: DAS CONSEQUÊNCIAS ÀS RESISTÊNCIAS

(Versão Original)

FABIANO FELIX TEIXEIRA

SÃO PAULO 
UNIVERSIDADE DE SÃO PAULO

FACULDADE DE FILOSOFIA, LETRAS E CIÊNCIAS HUMANAS

DEPARTAMENTO DE GEOGRAFIA

PROGRAMA DE PÓS-GRADUAÇÃO EM GEOGRAFIA HUMANA

FABIANO FELIX TEIXEIRA

\section{O PROCESSO DE DESFAVELIZAÇÃO: DAS CONSEQUÊNCIAS ÀS RESISTÊNCIAS}

(Versão Original)

Dissertação apresentada ao Programa de Pós-Graduação em Geografia Humana da Faculdade de Filosofia, Letras e Ciências Humanas da Universidade de São Paulo como parte dos requisitos para obtenção do título de Mestre em Geografia.

Orientadora: Prof. ${ }^{\text {a }}$ Dra. Ana Fani A. Carlos

SÃO PAULO 
Autorizo reprodução e divulgação total ou parcial deste trabalho, por qualquer meio convencional ou eletrônico, para fins de estudo e pesquisa, desde que citada a fonte.

Teixeira, Fabiano Felix Teixeira

T266p 0 processo de desfavelizaçã̃o: das consequências às resistências / Fabiano Felix Teixeira Teixeira ; orientadora Ana Fani A. Carlos Carlos. - São Paulo, 2018 .

$124 \mathrm{f}$.

Dissertação (Mestrado) - Faculdade de Filosofia, Letras e Ciểncias Humanas da Universidade de São Paulo. Departamento de Geografia. Area de concentraçắo: Geografia Humana.

1. Produção do espaço. 2. Operaçắo urbana. 3. Resistência à urbanização. 4. São José dos Campos. 5. Espaço urbano. I. Carlos, Ana Fani A. Carlos, orient. II. Iitulo. 
TEIXEIRA, Fabiano Felix. $O$ processo de desfavelização: das consequências às resistências. Dissertação apresentada à Faculdade de Filosofia, Letras e Ciências Humanas da Universidade de São Paulo para obtenção do título de Mestre em Geografia Humana.

Aprovado em:

Banca Examinadora

Prof. Dr.

Instituição:

Julgamento:

Assinatura:

Prof. Dr.

Instituição:

Julgamento:

Assinatura:

Prof. Dr.

Instituição:

Julgamento:

Assinatura: 
Von Einem gewissen

Punkt gibt es keine

Rückkehr.

Dieser Punkt ist zu

erreichen.

- Franz Kafka.

De um ponto

determinado em diante, não há mais retorno.

Este é o ponto a ser alcançado.

- Tradução livre. 


\section{AGRADECIMENTOS}

Gostaria de agradecer especialmente e em primeiro lugar aos meus familiares por todos esses anos de apoio e amor incondicional.

Agradeço a Ana Fani por tudo que me ensinou e orientou, e por aguentar minhas loucuras, teóricas ou não, e pelas intermináveis discussões nos grupos de estudo. Agradeço também aos demais bons professores que tive na graduação, em especial os mais provocadores e que me fizeram pensar, como Manoel Fernandes, Amélia Damiani, Antônio C. R. "Tonico" Moraes e Anselmo Alfredo.

Aos amigos mais queridos, eles sabem quem são e isso dispensa qualquer lista, agradeço profundamente pelo amor, ajuda, apoio, ideias e debates dos mais profundos.

Agradeço especialmente aos colegas do mestrado, todos e todas fundamentais para esse processo de reflexão e escrita. Um nome precisa ser necessariamente destacado: obrigado Renan, por toda a ajuda e apoio que me direcionou.

Agradeço a Giulia por todo sentimento, amor e carinho que me direcionou. Sem você eu não teria chegado nem na metade do caminho. Nosso Ravi está chegando!

Por fim, agradeço principalmente e em lugar de destaque máximo, aos para mim desconhecidos e desconhecidas ocupantes que tomaram o CRUSP em plena ditadura militar, e me possibilitaram fazer a graduação com sua luta por permanência. Graças a uma ocupação esse trabalho foi possível de ser elaborado, e sem ela nada teria se realizado para mim. A TAZ que vocês construíram, de certa forma, ainda vive no coração de muitos cruspianos. 
TEIXEIRA, Fabiano Felix. O processo de desfavelização: das consequências às resistências. Dissertação apresentada à Faculdade de Filosofia, Letras e Ciências Humanas da Universidade de São Paulo para obtenção do título de Mestre em Geografia Humana.

\section{RESUMO}

O processo de remoção de favelas empreendido pelo poder municipal na cidade de São José dos Campos, SP, foi uma operação urbana que marcou de maneira decisiva o espaço da cidade. Esse processo revelou a face violenta do processo de urbanização, manifesta sobretudo para a população mais pobre. Diante da cidade vivida por eles como privação, surgem os movimentos de resistência à urbanização em suas variadas formas contestatórias. Nossa pesquisa buscou desvendar os conteúdos dessas formas de resistência ao processo de urbanização, além de investigar as formas pelas quais essas contestações podem ser lidas do ponto de vista da produção do espaço. Para isso, realizamos uma leitura dos processos violentos inerentes à urbanização, sobretudo aqueles que são presentes nos setores mais pobres da sociedade e se manifestam através da vida cotidiana, colocando-os em uma situação de urgência da qual emergem as resistências. Analisamos, assim, quais são os processos que realizam as variadas formas de violência a que são expostas essas pessoas e quais as formas encontradas por elas de resistir.

Palavras-chave: Produção do Espaço; Operação urbana; Resistência à Urbanização; São José dos Campos. 
TEIXEIRA, Fabiano Felix. The process of removal: from the consequences to the resisilences. Dissertação apresentada à Faculdade de Filosofia, Letras e Ciências Humanas da Universidade de São Paulo para obtenção do título de Mestre em Geografia Humana.

\begin{abstract}
The process of removal of favelas undertaken by the municipal power in the city of São José dos Campos, SP, was an urban operation that marked in a decisive way the space of the city. This process revealed the violent face of the urbanization process, manifested mainly for the poorest population. Faced with the city lived by them as deprivation, the movements of resilience to urbanization appear in their various contestatory forms. Our research sought to uncover the contents of these forms of resilience to the process of urbanization, as well as to investigate the ways in which these challenges can be read from the point of view of space production. To do this, we carry out a reading of the violent processes inherent to urbanization, especially those that are present in the poorest sectors of society and are manifested through daily life, putting them in a situation of urgency from which the resiliences emerge. We analyze, therefore, what are the processes that carry out the various forms of violence to which these people are exposed and what forms they resist.
\end{abstract}

Keywords: Space Production; Urban operation; Resilience to urbanization; São José dos Campos. 


\section{LISTA DE MAPAS}

Mapa 1: As áreas iniciais de investigação da pesquisa pg. 10

Mapa 2: Desfechos da remoção .pg. 17

Mapa 3: Local da comunidade removida. pg. 29

\section{LISTA DE DOCUMENTOS}

Documento 1: Parecer Técnico do IPT pg. 21

Documento 2: Jornal local sobre financiamento bancário do projeto pg. 23

Documento 3: Jornal local sobre a proposta de urbanização de favela. pg. 24

Documento 4: Jornal local sobre as promessas de emprego feitas para adesão. .pg. 25

Documento 5: Jornal local sobre o não cumprimento da promessa de emprego. ..pg. 26

Documento 6: Jornal local sobre o ultimato às famílias para adesão. .pg. 27 


\section{ÍNDICE}

INTRODUÇÃO

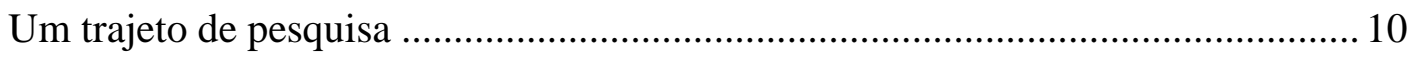

Questão central e questões secundárias ................................................................ 14

CAPÍTULO I - Áreas de investigação: Comunidade, Ocupação, Casas Conquistadas e Bairro

Novo Erro!

\section{Indicador não definido. 9}

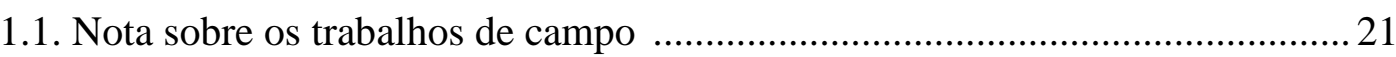

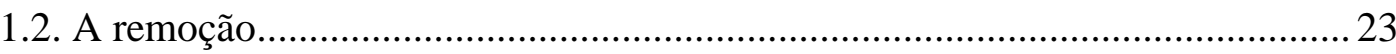

1.2.1. Local da comunidade removida: o bairro Vila Industrial (1).......................31

1.2.2. A ocupação no centro: a estação de trem (2).................................................36

1.2.3. As casas conquistadas (3)..........................................................................

1.2.4. O bairro novo: Jardim São José II (4).........................................................46

CAPÍTULO II - Sobre a produção do espaço urbano..........................................................54

2.1. A produção do espaço na disputa ..................................................................... 54

2.2. O papel do espaço urbano na disputa ………………………………….......... 59

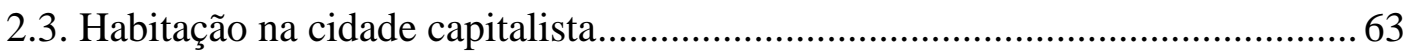

2.4. As soluções habitacionais na cidade capitalista..................................................65

2.5. O papel do Estado na cidade capitalisa ............................................................ 70

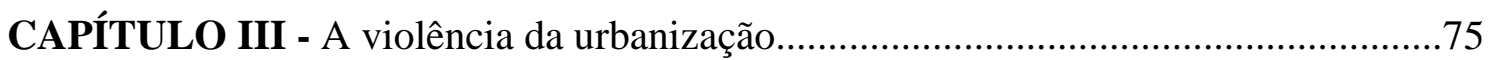

3.1. Segregação e violência na cidade capitalista.......................................................76

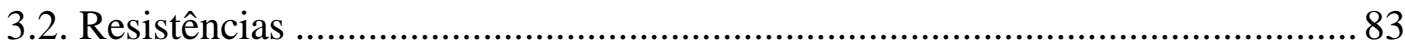

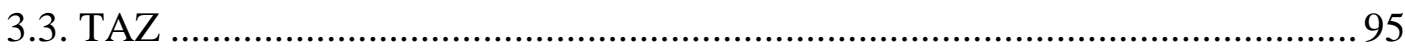

3.4. TAZ, Momentos e Situações …………………………………………….... 108

Consideraçôes Finais .........................................................................................111

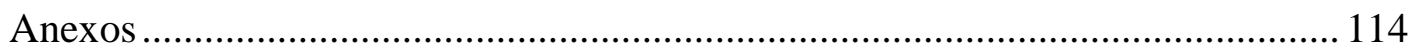

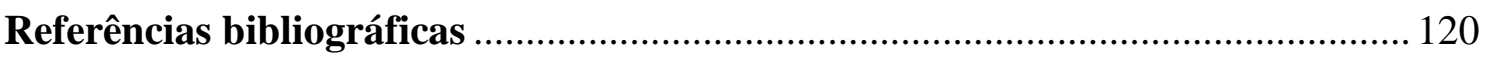




\section{INTRODUÇÃO}

\section{Um trajeto de pesquisa}

Essa pesquisa se propôs, em seu início, investigar o processo de desfavelização levado a cabo pelo poder municipal, em parceria com grandes órgãos financeiros internacionais, na cidade de São José dos Campos, SP. Esse processo foi planejado e executado por meio do programa habitacional "Habitar São José", no qual se almejava erradicar todos os núcleos de favelas do município.

$\mathrm{Na}$ zona leste da cidade, em uma parte ainda relativamente próximo ao centro, localiza-se o bairro Vila Industrial, um bairro residencial. Ao lado desse bairro ficava a comunidade conhecida pelos seus moradores como "Morro do Regaço", cujo nome de bairro oficial era Nova Tatetuba. Essa comunidade e mais outras duas, Nova Detroit e Caparaó, foram incluídas no programa de desfavelização municipal que visava removê-los para um bairro 12,3 km mais distante, construído nos limites da zona leste, um trajeto de mais de uma hora em ônibus a partir do local antigo da comunidade. Várias remoções seguiram-se a essas, culminando no caso mais famoso do Pinheirinho, de repercussão internacional. Apesar da maior divulgação, decorrente da violência desproporcional com que foi feita, a remoção do Pinheirinho não foi a primeira nem a última a acontecer na cidade, apenas a mais conhecida pelo grande público.

Em 2003 eu ainda residia naquela região e pude testemunhar a violência dessa operação, gerando assim minha primeira pergunta: por que eles estão sendo removidos? Partia-se, então, das questões mais óbvias sobre o fenômeno observado. Por questões de proximidade, a comunidade ${ }^{1}$ do Morro do Regaço, na qual eu conhecia pessoas e frequentava espaços em comum com elas, foi a que mais me chamou atenção. Essa comunidade foi removida pelo poder municipal no dia 30 de dezembro de 2003, com a demolição da maioria

\footnotetext{
${ }^{1}$ Foi feita uma opção nesse trabalho pelo termo comunidade ao invés do termo favela. Como a comunidade é um termo surgido da prática social, acreditamos que, do ponto de vista da Geografia crítica, esse termo possui mais força do que o termo favela. Além disso, esse termo era mais comum nas entrevistas e falas dos moradores. Mais à frente discutiremos a definição do termo favela e suas implicações.
} 
das residências nesse dia. Ali permaneceu por mais de vinte anos, abrigando 223 famílias. De acordo com o discurso oficial, eles foram removidos para o "bem deles", já que aquela área representava um risco do ponto de vista ambiental por ser área de proteção permanente, pois ela beirava o córrego Cambuí. Representava também, ainda de acordo com o discurso oficial, um risco do ponto de vista da segurança, por ser uma área de beira de encosta e já ter acontecido ali um pequeno deslizamento de terra que vitimou uma criança. Por fim, representava um "risco urbanístico", uma vez que seu padrão de urbanização, identificado como favela, não se encaixava no modelo previsto pela ocupação considerada regular da cidade, ou seja, não se adaptava aos arquétipos residenciais da classe média ou aos moldes legais da propriedade privada urbana.

Já que se tratava de uma remoção para o "bem dos moradores", por que a grande maioria deles não desejava ir? Houve grande resistência popular à operação. Pinturas de protesto foram postas nos muros das casas que beiravam a avenida, vários atos foram organizados pelos moradores, nas ruas da cidade e em frente ao Paço Municipal, além de vários processos burocráticos na tentativa de barrar a intervenção, como, por exemplo, um laudo feito pelo IPT-USP que contestava o laudo da prefeitura sobre o risco de desabamentos.

Em um primeiro momento, já no Departamento de Geografia da Universidade de São Paulo, escrevendo meu Trabalho de Graduação Individual, investiguei esse programa habitacional tentando responder quais as reais motivações que levaram esse processo de remoção adiante, uma vez que os moradores haviam resistido a ele. Descobri que o programa foi financiado pelo Banco Interamericano de Desenvolvimento (BID), mediado pelo governo federal e em parceria com o governo do Estado, empreendido e desenvolvido ao longo de duas gestões municipais consecutivas de Emanuel Fernandes (1996-2004), PSDB e duas gestões de Eduardo Cury (2004-2012), do mesmo partido. Uma série de metamorfoses urbanas foi empreendida pela prefeitura no espaço da cidade, em especial na zona leste, em um processo de produção do espaço extremamente rápido e violento.

O trajeto intelectual percorrido nesse primeiro momento partiu de questões simples: por que esse espaço na cidade está disponível e mesmo assim as pessoas estão sendo removidas? Por que construir outra coisa e não deixar a comunidade? A qual projeto essa comunidade representa empecilho? Evidentemente, ao longo da graduação, houve um amadurecimento dessas questões mais básicas para níveis mais profundos de reflexão. Ao final da pesquisa, a questão central apresentava-se da seguinte forma: qual a contradição 
entre o "novo urbano"2 que se constitui e a presença da comunidade? Por que esse "novo urbano" não pôde incorporar a comunidade? Assim, a discussão foi empreendida no sentido de compreender que, na cidade sob domínio do capital, a reprodução do espaço urbano encontra na propriedade privada, seu fundamento, cuja lógica associa-se ao mundo da mercadoria, que objetiva a realização do valor de troca e, consequentemente, visa a expansão do valor de troca sobre o valor de uso, levando à tona a contradição de um espaço urbano produzido socialmente e apropriado privadamente como condição de realização do lucro em um momento em que o próprio espaço torna-se mercadoria. Assim foi possível ir à fundo na questão: como podemos nos aproximar dos processos que estão por trás da sensível desigualdade que aparece materialmente na cidade a partir desse fragmento? Que aspectos mais gerais ele permite iluminar?

As antigas áreas de entorno das comunidades passaram, e ainda passam, por processos de valorização do espaço decorrentes da remoção e de posteriores obras de infraestrutura empreendidas pela prefeitura. Houve a instalação de grandes empreendimentos comerciais e imobiliários, além de uma sensível verticalização com a construção de diversos edifícios de moradia. Podemos afirmar que as mudanças na morfologia da área vinham acompanhadas de uma metamorfose do cotidiano dos atuais moradores do bairro de onde saíram as comunidades, a Vila Industrial, em especial na parte do bairro onde ficava o Morro do Regaço. A partir dessas mudanças nos locais das antigas comunidades abria-se o horizonte para a compreensão da lógica da ação realizada pelo Estado, iluminando os interesses que estavam em jogo na remoção das comunidades na cidade de São José dos Campos.

Ao longo da pesquisa para o TGI, houve uma descoberta importante de um processo político desconhecido no momento em que a proposta inicial havia sido elaborada: uma ocupação vinculada ao movimento de lutas por moradia. Embora a maior parte dos moradores do Morro do Regaço, seguindo a determinação da prefeitura, tenha se mudado para o bairro novo, outra parte não aceitou aderir ao programa e não se mudou para a nova localidade determinada pelo poder municipal. Após sua remoção do Morro do Regaço, eles acabaram mobilizando-se para uma ocupação no centro. Uma antiga estação de trem desativada na borda norte do centro foi escolhida, com dois grandes galpões abandonados e

\footnotetext{
${ }^{2}$ Esse "novo urbano" na verdade apenas aparece como novo. Don ponto de vista dos que ficam, ele muitas vezes representa uma ideia de progresso e melhora do espaço do bairro. Do ponto de vista da Geografia Crítica, esse "novo" insere-se no movimento geral da reprodução do espaço urbano.
} 
algumas estruturas antigas, como pequenas casas para estoque. A ocupação ocorreu no dia 25 de janeiro de 2004 (26 dias após a remoção) com vinte e duas famílias. Um longo processo de lutas foi iniciado e várias ações políticas dali partiram.

\section{As Áreas Iniciais de Investigação da Pesquisa}

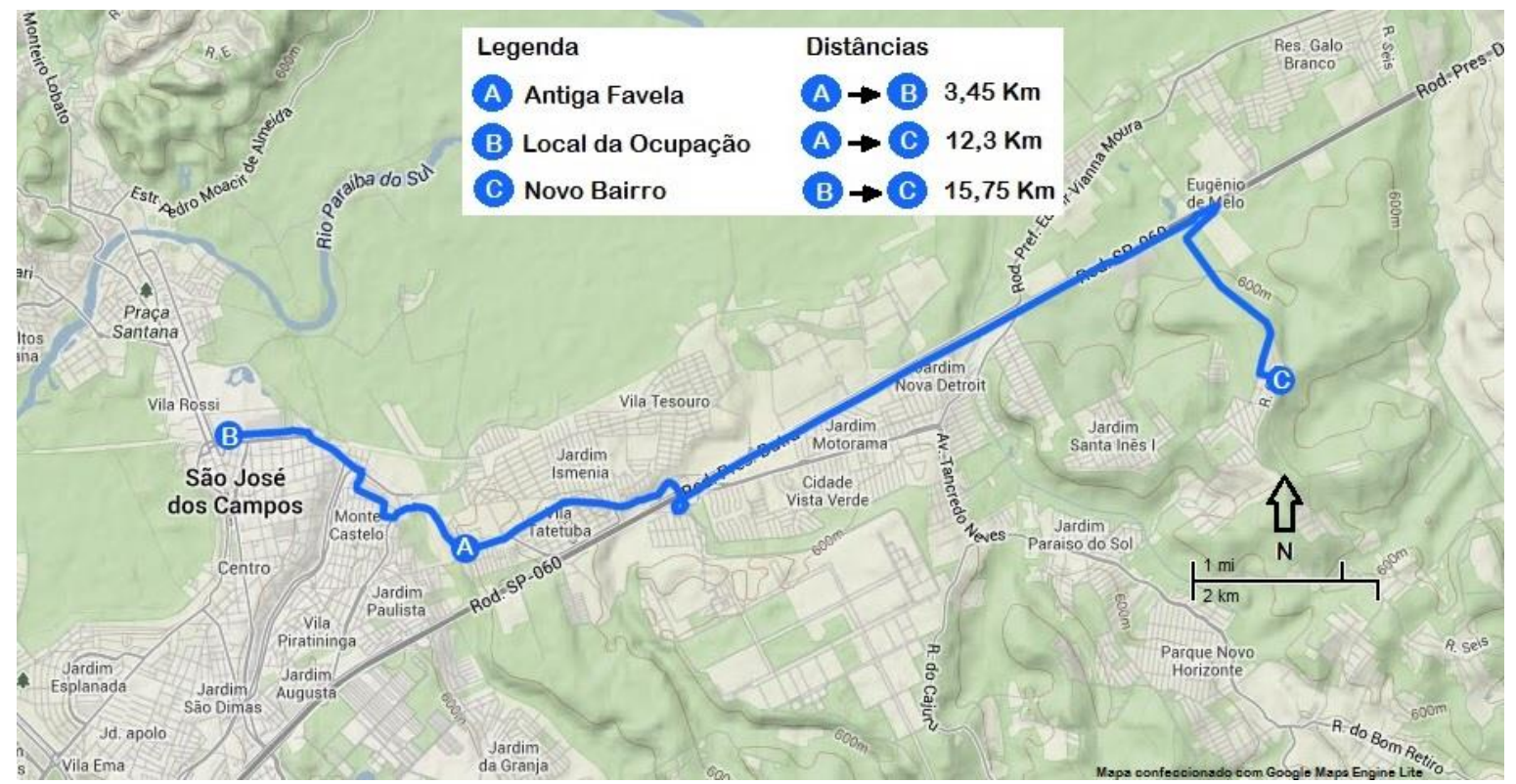

Mapa 1: As áreas de interesse para nossa investigação, com as distâncias em quilômetros. Importante ressaltar que as linhas de ônibus percorrem distâncias ainda maiores, considerando que, no mapa, estão traçados os caminhos mais rápidos. Fonte: Google Maps (2014).

Diante do exposto, o papel da ocupação cresceu na pesquisa e o tema dela transitou para as formas de resistência proporcionadas por essa ação política. Construímos assim outra hipótese: fruto do mesmo processo homogeneizante que retirou a comunidade, a ocupação aparecia como uma resistência, uma diferença produzida em meio ao homogêneo decorrente da intervenção. Nenhum outro caso da longa lista de remoções que se seguiu na cidade, incluindo o famoso Pinheirinho, resultou em uma ocupação ou mesmo em algo semelhante. O foco, portanto, foi em como a ocupação possuía um papel político e sobre os conteúdos possíveis de, a partir dela, se desdobrarem: a ocupação era vista como um espaço heterogêneo produzido de maneira contraditória por um processo de homogeneização espacial. A partir dessa discussão, intentei debater o sentido das transformações na lógica da produção do espaço urbano, as estratégias de segregação, a cidade que aparecia apontando 
uma gestão voltada aos negócios urbanos pela mediação da prefeitura. No entanto, ganhava centralidade na análise o conceito de resistência, pois de alguma forma a ocupação aparecia, naquele momento do TGI, como um grupo de pessoas que resistiam aos projetos da prefeitura de remoção, resistiam às mudanças em seu cotidiano. Naquele momento, isso foi lido como uma resistência ao capital (uma ideia ainda um tanto vaga). Em alguma medida, isso derivava da leitura de que eles realizavam alguma transformação indesejada e não prevista pela ação capitalista.

Após o início da pesquisa de mestrado, essa ocupação teve seu desfecho final: após treze anos de duração, em 2016, depois um longo período de lutas e mobilizações, eles conseguiram do poder público uma casa própria por família, pela qual pagarão por alguns anos uma quantia quase simbólica de $\mathrm{R} \$ 25,00$ por mês. As casas são relativamente próximas do local de onde eles foram removidos, todas na mesma rua.

\section{Questão central e questões secundárias}

No mestrado pude recolocar algumas questões levantadas na pesquisa do TGI e redimensionar outras uma nova perspectiva. A remoção da comunidade Morro do Regaço, como consequência da desfavelização, tinha provocado um conflito que ganhava a forma de uma resistência. Houve a produção de uma resistência ao processo como fruto da própria operação urbana. Portanto, discutiremos aqui um movimento de homogeneização do espaço que, ao tentar normatizar e padronizar o espaço urbano, produz o seu contrário: um espaço heterogêneo, da diferença, de resistência.

A principal mudança na abordagem do mestrado foi justamente no conceito mais central de todos: a resistência. Era de alguma forma um tanto vaga a ideia presente no TGI de "resistir ao capital". Quem é exatamente “o capital"? A que eles resistem exatamente? Como analisar corretamente o que resiste e o que não resiste a ele? Como diferenciar qualitativamente as diferentes formas pelas quais essa resistência se manifesta? Na realidade, abria-se para a reflexão a necessidade de desvendar a lógica da produção do espaço sob a orientação da acumulação.

Pensando em um direcionamento mais claro para essas questões, a ideia de resistência foi recolocada de uma forma mais específica: diante da condição de urgência e de necessidade a que são expostos pela remoção, eles resistem a essa face violenta do 
processo de urbanização. Isso mudou completamente os conteúdos das antigas formulações: a ideia da resistência ao capital e sua lógica, da forma como estava na pesquisa anterior de TGI, era muito vaga e indefinida. Resistir à urbanização em sua face mais violenta possui um caráter mais concreto e definido.

Agora formulamos uma tese, que será a defendida por essa dissertação de mestrado, segundo a qual o processo contraditório de produção do espaço produz movimentos de resistência à urbanização. Esses movimentos resistem ao processo de constituição do urbano sob a lógica da acumulação, manifesto para eles em sua face mais violenta. A urbanização não se constitui com igual violência para todas os grupos que compõem a cidade, pois fica evidente que as pessoas que viveram a remoção foram expostas à níveis de brutalidade e expropriação que grupos de classe média não vivenciam normalmente. Essa urbanização em sua face mais violenta gera parcelas da sociedade que resistem e lutam da maneira que podem, diante da condição de urgência a que são constantemente colocadas. Com essa ideia mais específica, formula-se a questão central que agora baliza toda a discussão dessa nova pesquisa: do ponto de vista da produção do espaço, quais os conteúdos do processo de resistência à urbanização?

Para uma melhor aproximação dessa questão central, parto da seguinte hipótese, formulada à luz de duas importantes ideias de Ana Fani Carlos e Fabiana Valdoski Ribeiro: a cidade contemporânea, sob a égide da urbanização capitalista, é vivida como privação (Carlos, 2017). Nesse sentido, morar nela já é, de certa maneira, uma forma de resistência (Ribeiro, 2017).

A produção da cidade capitalista traz como exigência de todos os seus moradores algum grau de resistência, em maior ou menor intensidade, aos processos desumanizantes da produção capitalista do espaço, sempre de forma desigual, pois é evidente que numa sociedade de classes a desigualdade da condição de como vivem e usam a cidade gera diferenças qualitativas e quantitativas de resistência. Isto é, as mesmas contradições não estão postas para todos, nem qualitativamente nem quantitativamente. $\mathrm{O}$ que as classes têm em comum: a não possibilidade dos ricos de fugir dos problemas urbanos que afligem a todos. Outro ponto é que não se realizam em seu potencial de criadores como seres humanos, no sentido lefebvriano de obra, apenas usufruem de posições distintas e hierarquizadas em uma estrutura de consumo da qual todo cidadão deve participar.

Em algum sentido, cabe aqui uma pequena analogia com o argumento da "dominação sem sujeito" do capital (KURZ, 2000), segundo o qual todas as pessoas estariam vitimadas pela lógica do tempo abstrato de trabalho, desumanizados pelo tempo do relógio e pelo ritmo 
da modernidade, ainda que estejam em diferentes posições na hierarquia de consumo. Não precisamos, necessariamente, concordar com todos os termos da dominação sem sujeito para percebermos que esse argumento carrega em si parte do raciocínio anteriormente exposto: de que todos na cidade vivem em alguma medida um grau de desumanização.

Contudo, esse processo desumanizante não se torna absoluto, resistências em diversos níveis e escalas se constituem em maior ou menor grau. Embora uma parte da vida possa sucumbir à homogeneização, restam resíduos que guardam conteúdos próprios, enquanto outros são produzidos como produto indesejado da própria ação opressora dos agentes hegemônicos da produção do espaço.

Essa hipótese proporcionou outra mudança de perspectiva em relação à antiga pesquisa: os que se mudaram para o bairro novo eram vistos como os que "aceitaram" passivamente a intervenção, apenas os membros da ocupação eram vistos como resistência (e esse resistir visto naquela pesquisa ainda em sua concepção mais vaga ${ }^{3}$ ). Portanto, a comparação feita naquele momento era entre os que resistiram e os que não resistiram. Faltava a perspectiva de que os moradores do "bairro novo" resistem à sua maneira, de diversos modos. Tratam-se apenas de formas diferentes, em condições diferentes, de resistência. Evidentemente, essas diferenças entre ambas produziram resultados diversos, e esses conteúdos poderão ser mais bem esmiuçados ao comparar as formas de manifestação da resistência à urbanização nos distintos contextos.

Do ponto de vista espacial, qual o papel dessas resistências na produção do espaço? Existe uma produção do espaço por parte dos agentes hegemônicos. Se há uma produção do espaço por parte dos agentes hegemônicos, há também um processo em disputa. A remoção da comunidade Morro do Regaço gerou o seu outro, houve uma subversão da solução imposta. Ao invés de se mudarem para a periferia, ocuparam uma área central dando visibilidade a sua luta. Os que se mudaram para o bairro novo também criaram suas formas específicas de resistência, em outras condições e sem a mesma visibilidade. Existe uma produção do espaço como espaço de resistência. Eles produzem outra face da cidade, pois eles vivem outra face da urbanização, mais violenta. Como esse espaço é produzido? Qual sua natureza e suas especificidades? Essas são as perguntas a serem respondidas para direcionar a questão central da pesquisa. Para tentar responder melhor nossas questões, observamos os conteúdos do ponto de vista da ação política no contexto local (1), da relação dos removidos com o espaço (2) e das formas de consciência que podem surgir da condição

\footnotetext{
${ }^{3}$ No presente trabalho, o ponto de partida não é pensar o capital genericamente como categoria, mas sim a prática social que coloca esses moradores como sujeitos contestadores de um projeto de urbano imposto a eles.
} 
de urgência vivida (3) para ir do mais específico ao mais geral e, assim, atingir nossa contradição fundamental: aquela entre o uso e a troca, entre a cidade produzida como valor de troca sendo imposta aos que resistem para dela se apropriarem enquanto valor de uso. Nossa contradição fundamental, portanto, é a do espaço do valor de uso, produzido visando a realização do uso como forma de acesso a realização da vida, e a do espaço do valor de troca, isto é, a lógica da acumulação orientada para a produção do espaço.

1 - Quais as especificidades desse processo? O que significa essa remoção em São José dos Campos? Como em São José dos Campos se construíram as formas de expropriação da população? Como o uso do espaço foi submetido pela prefeitura ao mercado? O que representou a ocupação em São José dos Campos? A espoliação urbana em São José dos Campos é resultado de uma história de valorização de um eixo industrial, de uma urbanização voltada para a industrialização. O resultado visível foi o aumento da pobreza urbana e a possibilidade sempre presente de uma piora repentina de suas condições devido a sua constante situação de vulnerabilidade. Nesse enquadramento geral surge um movimento de lutas por moradia na cidade.

2 - Quais as práticas espaciais derivadas desse embate entre um processo de homogeneização e a produção do seu outro? Produziram-se estratégias de coerção, de imposição da urbanização em sua face mais violenta, ao mesmo tempo em que foram gestadas estratégias cotidianas de resistência e ação. A cidade vivida como privação (contradição entre escassez e abundância) coloca a hipótese de que na urbanização capitalista a resistência é um ato cotidiano. Daí desdobram-se as questões: até que ponto o ato de viver na cidade pode ser visto como resistência? Como e até que ponto viver no bairro novo ou na ocupação é também uma forma de resistência e em que sentido?

3 - Se partimos da hipótese de que houve em alguma medida um despertar crítico possibilitado pela ocupação, permitindo a criação de uma consciência da expropriação, nos perguntamos: como a resistência mobiliza uma consciência sobre o processo espoliativo? Seria uma consciência transformadora? Quais seus limites, possibilidades e contradições? Como a ocupação fruto de uma remoção leva seus ocupantes a pensar esse processo da intervenção estatal na cidade?

O que mobiliza essa pesquisa, portanto, é a constatação de uma mudança drástica no espaço urbano da cidade que, apesar de sua nitidez e obviedade, não revela quais processos estão ocultos por trás de tão rápidas transformações das formas urbanas. A questão maior da produção do espaço nos coloca diante de um fragmento - a desfavelização e suas consequências - através do qual pretendemos chegar até a totalidade que revele os conteúdos 
dessa produção social do espaço. A noção de totalidade aqui buscada é uma noção aberta, não estruturada, que dê conta do movimento contraditório da realidade e contemple o movimento do devir. O plano da forma emerge, nessa perspectiva dessa dialética, como um momento importante e necessário, mas não suficiente. Parte-se então ao plano dos conteúdos na tentativa de captar um movimento e um processo. Por fim, realiza-se um retorno ao plano do concreto, da forma, que agora não mais aparece como um quadro caótico, mas como uma totalidade, um concreto pensado. 


\section{CAPÍTULO I - Áreas de investigação: Comunidade, Ocupação, Casas Conquistadas e Bairro Novo}

O recorte específico de nosso fragmento foi a primeira remoção, feita na Vila Nova Tatetuba, inaugurando uma longa lista de desapropriações em comunidades que culminou no caso mais famoso da cidade: o Pinheirinho. O caso da nova Tatetuba, conhecida por seus moradores como Morro do Regaço, é importante por uma série de razões: foi a primeira remoção de São José dos Campos no contexto do programa habitacional "Habitar São José", datando de 2003, cujo objetivo era realocar os moradores expulsos de comunidades em vários pontos da cidade; demandou a construção de um novo bairro nos limites da cidade, o que só foi feito para as três primeiras remoções, que aconteceram de forma quase simultânea; foi a que mais repercutiu na mídia local até o caso do Pinheirinho; por fim, foi a única em que os moradores, contestando a ação da prefeitura, recusaram-se a aceitar a solução de mudança para a periferia, permanecendo no centro em uma área de ocupação.

Essa investigação articulou quatro lugares considerados centrais para a compreensão do fragmento aqui estudado: a área onde ficava a comunidade removida, o bairro novo construído pelo poder público na periferia da cidade, a ocupação no centro e o local no qual foram conquistadas as casas pelos membros da ocupação. Cada um desses quatro lugares revela um aspecto de um processo geral que nos aproxima dos conteúdos da reprodução do espaço urbano na cidade contemporânea: mostram como a lógica da acumulação aplicada ao espaço realiza-se através da expulsão e, nesse sentido, da violência. Cada um deles ilumina uma face diferente da violência do processo de urbanização e, consequentemente, permite a reflexão das formas de resistência a esse processo. Portanto, esses locais foram escolhidos como relevantes para nosso recorte de pesquisa e serão analisados de forma aprofundada mais adiante. Por ora, nos limitaremos apenas a justificar a escolha dessas quatro áreas de investigação. 


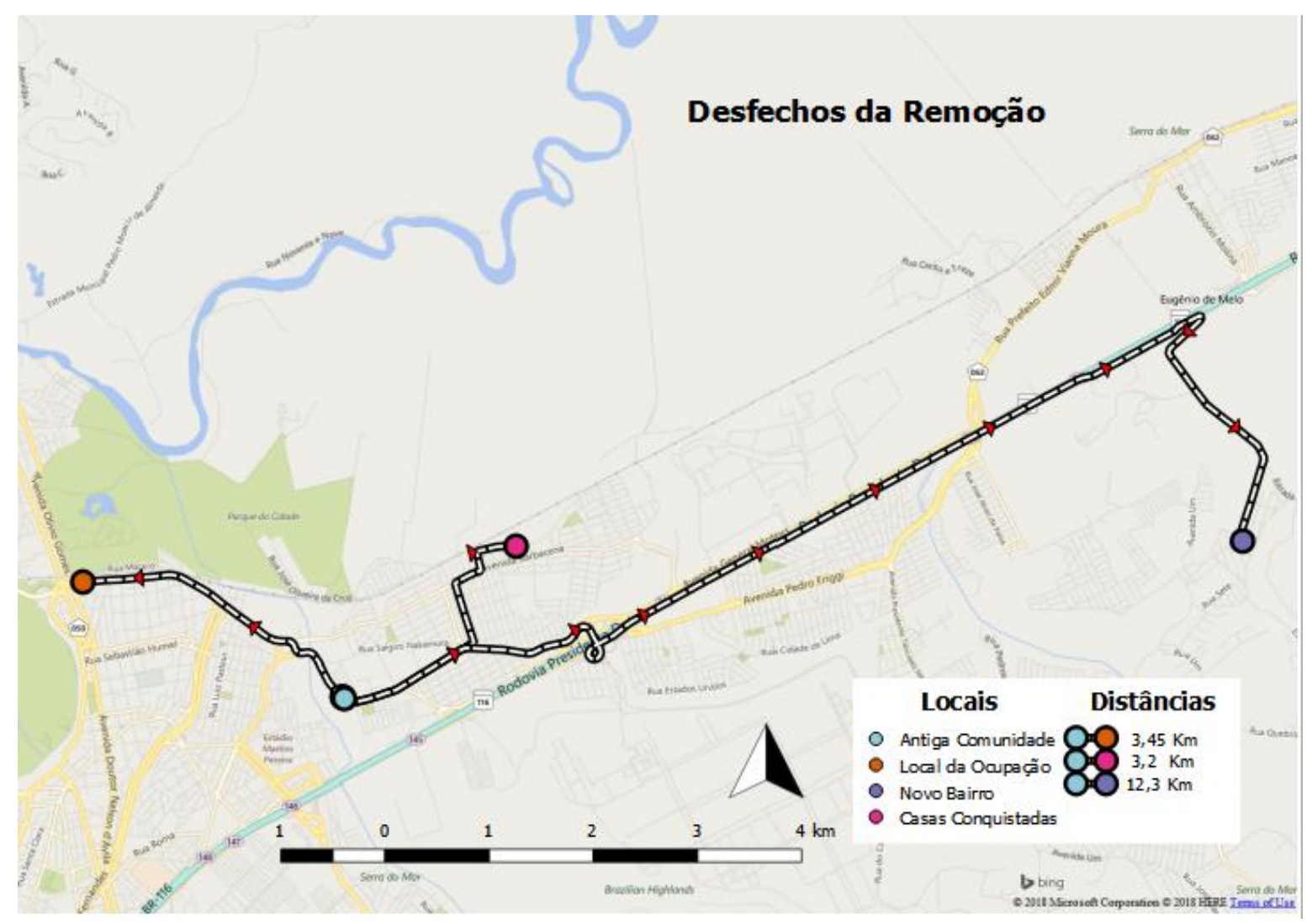

Mapa 2: Estão aqui retratados os desfechos para a população removida. As distâncias marcadas no mapa seguem o percurso mais rápido de carro. Em transporte público, elas seriam ainda maiores dado que os ônibus nem sempre fazem o menor caminho.

Retomando, para melhor esclarecimento e clareza da exposição, os fatos aqui narrados: os moradores da comunidade Morro do Regaço, ponto A, foram expulsos de lá pelo poder municipal e, dali, tomaram dois caminhos distintos. Uma pequena dos moradores, cerca de vinte famílias, empreendeu uma ocupação no centro da cidade, no ponto B; a maior parte das pessoas expulsas, no entanto, não participou da ocupação. Eles foram realocados em uma região periférica da cidade, o bairro novo, no ponto $C$. Os que foram para a ocupação, no ponto B, conseguiram conquistar uma casa do poder municipal em local não muito distante de onde foram inicialmente removidos, quando ainda moravam na comunidade. Essas casas conquistadas são o ponto D.

No local da antiga comunidade (1), pudemos observar como a operação urbana empreendida pela prefeitura modificou aquele espaço. Isso nos mostrará, adiante, quais objetivos e/ou lógicas estavam envolvidas na remoção. Evidenciam-se ali, também, as consequências menos claras da remoção: as mudanças na vida dos que ficam. 
No local da ocupação no centro (2), observamos como se constituiu um espaço heterogêneo em relação ao processo homogeneizante da operação urbana. Ali foi possível analisar a constituição de resistência ao movimento de urbanização em sua face mais violenta e ao modo como isso constituiu um espaço diferente, desencadeando uma série de implicações que vão além da ocupação em si.

No local das casas conquistadas (3), vimos alguns desfechos do processo político iniciado pela ocupação e o início de um novo ciclo para aqueles moradores. A luta deles no espaço urbano agora toma outros conteúdos, assim como a ação nesse espaço agora é diferente em relação ao da ocupação. Ali foi possível aferir até que ponto houve um despertar crítico, a partir da vivência proporcionada pela ocupação, que transformou sua forma de lidar com o espaço da cidade.

No local do bairro novo (4), foi possível compreender como a remoção foi vivida pelos que se adequaram (em maior ou menor medida) ao plano original da prefeitura (entendendo assim algumas motivações para execução de tal projeto), a forma como tomaram consciência da remoção, os processos espoliativos associados à remoção, bem como formas menos evidentes de resistência (se comparadas com a ocupação).

\section{1. - Nota sobre os trabalhos de campo}

Nos tópicos seguintes serão discutidas as três áreas de interesse para essa pesquisa: a área onde ficava a comunidade do Morro do Regaço, o novo bairro Jardim São José II e a ocupação da estação de trem, escolhidas para análise dentro de nosso recorte empírico. Optei por mesclar as primeiras análises aos relatos de campo de forma a fazer uma primeira reflexão sobre a realidade vista em campo para, em momento posterior, aprofundar nossas questões.

Para levantar as informações da pesquisa, foram realizados diversos trabalhos de campo e entrevistas com o mínimo direcionamento possível. A maioria das entrevistas passava-se de forma muito parecida com uma conversa informal, pois dessa forma é possível maior abertura do entrevistado, em geral fornece resultados mais interessantes. Foi o que se mostrou mais frutífero. Além de uma escolha, essa abordagem em campo mostrou-se também uma necessidade: no bairro novo Jardim São José II, por exemplo, a questão da segurança pessoal mostrou-se um problema sério. Em todas as idas até o bairro novo, ocorreu 
alguma situação de receio, intimidação ou até mesmo de ameaças, causando a sensação de insegurança, de forma que isso dificultou o trabalho de campo, impossibilitando totalmente gravações ou visitas livres a qualquer morador. A única possibilidade segura de entrada se apresentou por meio de parentes que possuo lá. Minha presença como pesquisador era um segredo, portanto muitas entrevistas eram conversas com moradores que não sabiam de meu objetivo. Essa necessidade, em si, já é reveladora de aspectos essenciais da vida naquele lugar, por mostrar como a sensação de insegurança está presente e é vivida pelos moradores. Evidentemente, a vivência dessa sensação de insegurança não se dá de forma igual para um morador do bairro e novo e para um observador externo e desconhecido, porém mostra questões comuns a todos como, por exemplo, a ação constante do tráfico de drogas e sua vigilância de todos os movimentos que acontecem no bairro. Em dado momento, tive que me reportar a esse "poder local”, já que minha presença foi notada mesmo com toda minha discrição.

Para complementar as informações, utilizei-me do riquíssimo levantamento feito por João Brasil (2013) sobre o cotidiano dos moradores dali. Ele também relata em sua pesquisa a dificuldade de realizar um trabalho de campo no bairro e algumas ameaças, principalmente de pessoas identificadas por ele como ligadas ao tráfico de drogas. O que levou, de acordo com ele, ao risco constante de violência. Ainda assim ele conseguiu algumas valiosas entrevistas e muitos dados interessantes.

Na ocupação, apenas três entrevistas puderam ser gravadas, e, embora lá o convívio tenha sido um pouco mais aberto para conversas informais, eles em geral eram reservados quanto a pessoas de fora do seu meio social.

Nas casas conquistadas, o clima de conversa informal também mostrou melhores resultados. Apenas uma entrevista foi gravada. O clima nas casas novas era de muita alegria entre os moradores, diferente da atmosfera relativamente mais fechada da ocupação, portanto ali eles foram mais abertos a relatar sua experiência e o cotidiano do novo espaço.

Por fim, uma nota sobre a redação: esse ponto do trabalho será marcado por uma narrativa mais pessoal e subjetiva, que dê conta de minhas impressões e sensações durante a vivência em campo, o que envolve também uma percepção do silêncio e da impossibilidade de colher informações de alguns casos. Será a única parte do trabalho em que escreverei em primeira pessoa, visto que na parte de explicação (teórica) ninguém escreve sozinho. Acredito que contar como foram os campos, em detalhes, trará ricos dados para a reflexão. 


\section{2. - A Remoção}

O pretexto utilizado para remoção foi o fato de se tratar de área considerada de risco pelo poder municipal, pois uma parte das casas estava em área de mananciais próxima do córrego Cambuí e por se tratar de um terreno inclinado. $O$ primeiro passo para compreendermos os interesses por trás das remoções veio da pesquisa de campo. Um dos entrevistados nos informou que a confecção dos laudos para legitimar a remoção do ponto de vista técnico foi, no mínimo, duvidável: foram feitos 220 laudos em um único dia, assinados pela mesma pessoa, como justificativa para a intervenção. O IPT (Instituto de Pesquisas Tecnológicas) confeccionou um laudo posterior com uma opinião muito menos drástica sobre o local (Parecer Técnico nº 9 084-031 - 8/80). 
Todos os casos considerados como de risco muto alto $e$ alto (casas 7, 29, 60, A $78,109-8,63$ casa $C 2,210,190 / 191)$ estito relacionados à condicto do aterra, com

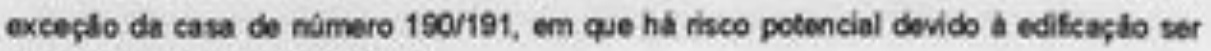
precinid em tormes construtivos.

Recomenda-se a reconstruçito do atero $\alpha$ execuejo de um reforço medianto obras.

Os casos considerades de riseo baiko a midio sto situaçles que requerem algum cuidado com a manutens to des aterros, sendo fundamental a implantas to do um sistema de drenagem superficial.

Tendo em vista que os riscos attos e muto alto slo localizados pontualmente e restritos a algumas casas, conclui-se que o tecreno como um todo nalo apresenta risco gecticrico de gandes movimentos de massa (sob).

Todos os casos descritos tem soluçto mediante intervençbes simples, visando at mininzzaça do dos riseos assinalados.

Deve ser mencionado que, embora alguns casos tenham sido considerados como de risco nula, os riscos devem ser watiados sempre sob um enfoque dinamico, pois o loteamerto carece de infraestrutura bisica e do fiscalizacto para construpla A inexistlocia de drenagem superfeial, assim cormo a falta do ordenamento para langamento de aguas servidas, associadas it construçio de fossat selpticas sem obodecer a ertibrios téenicos, poderáo prejudcar a estabilidade do terreno, princlpalmente nos locais onde os aterros apresentam espessura maior.

Sao Paula, 22 de setembro de 2004.

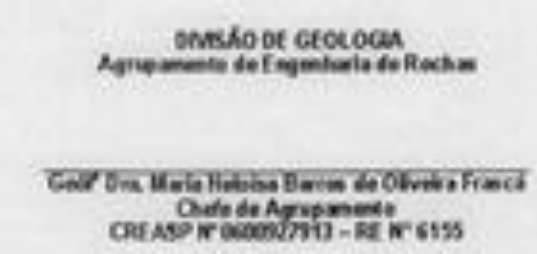

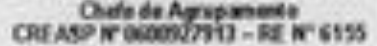

Documento 1 - Parecer Técnico do IPT. 
Oito casas segundo o instituto estavam em situação de risco, e apenas uma de risco alto. O parecer é claro em afirmar que simples intervenções poderiam sanar a situação dessas casas e minimizar as situações de risco. De acordo com Forlin e Costa (2010, p.134):

Vila Nova Tatetuba - Todas as famílias que residiam nessa favela foram expulsas e ou removidas do local, que era considerado zona de risco. Pouco tempo depois, O IPT (Instituto de Pesquisas Tecnológicas) forneceu um parecer afirmando que a área não possuía riscos de deslizamentos, como afirmado pela Prefeitura. Naquele espaço, deu-se a construção do Hipermercado Carrefour, bem como prédios residenciais voltados à classe média. Um grupo de ex-moradores da favela Nova Tatetuba, conhecida como Morro do Regaço, se negaram a ir para as casas construídas no Jardim São José II e ocuparam a antiga estação de trem.

O banco que financiou o programa, BID, surge nas falas dos antigos moradores da comunidade como o grande vilão da remoção, por violar suas próprias diretrizes aceitando financiar o projeto à revelia das necessidades locais. Muitas mudanças foram propostas pela comunidade ao BID, porém eles relatam que não foram ouvidos. 


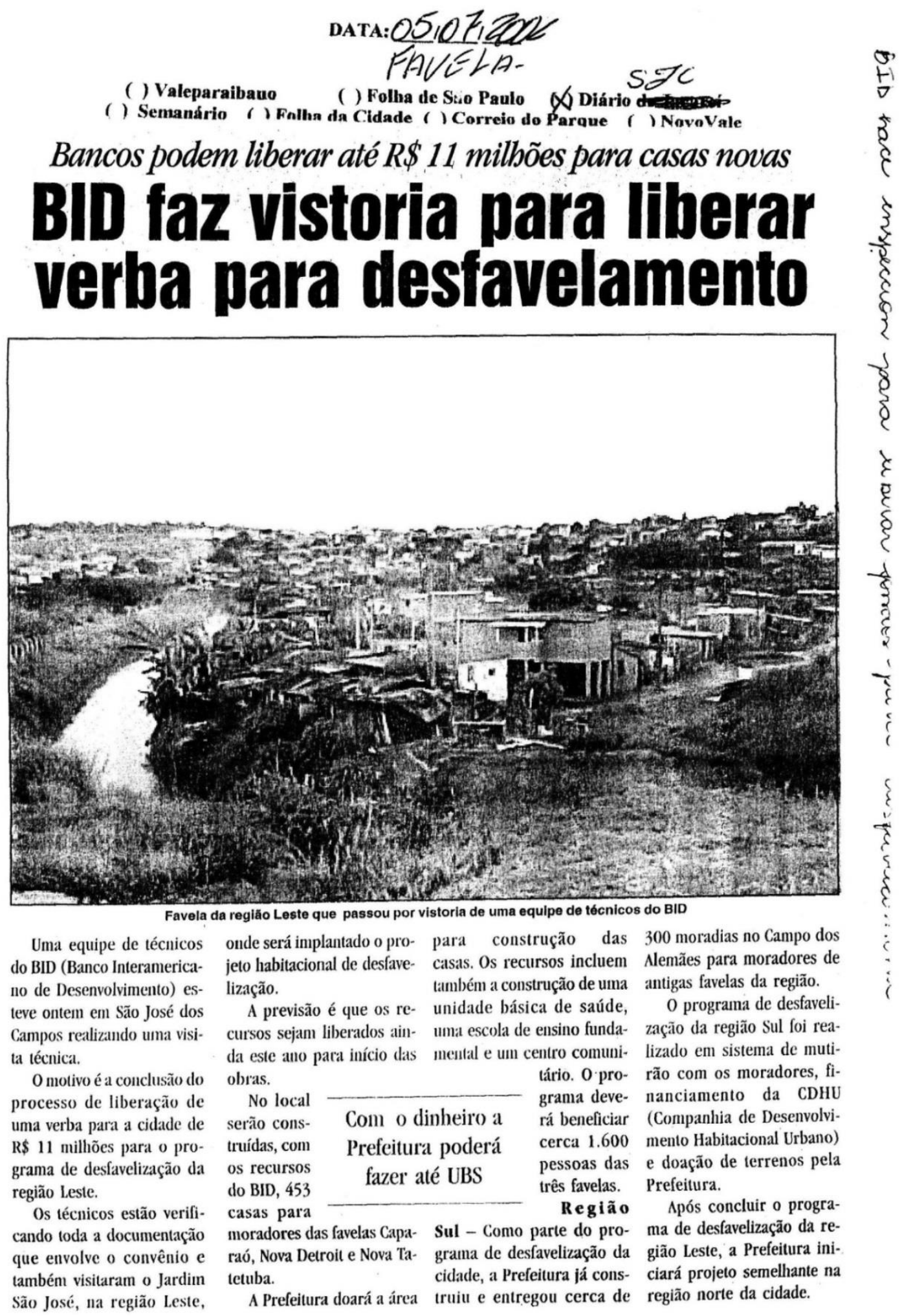

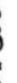




\section{FOLHA}

VA L E

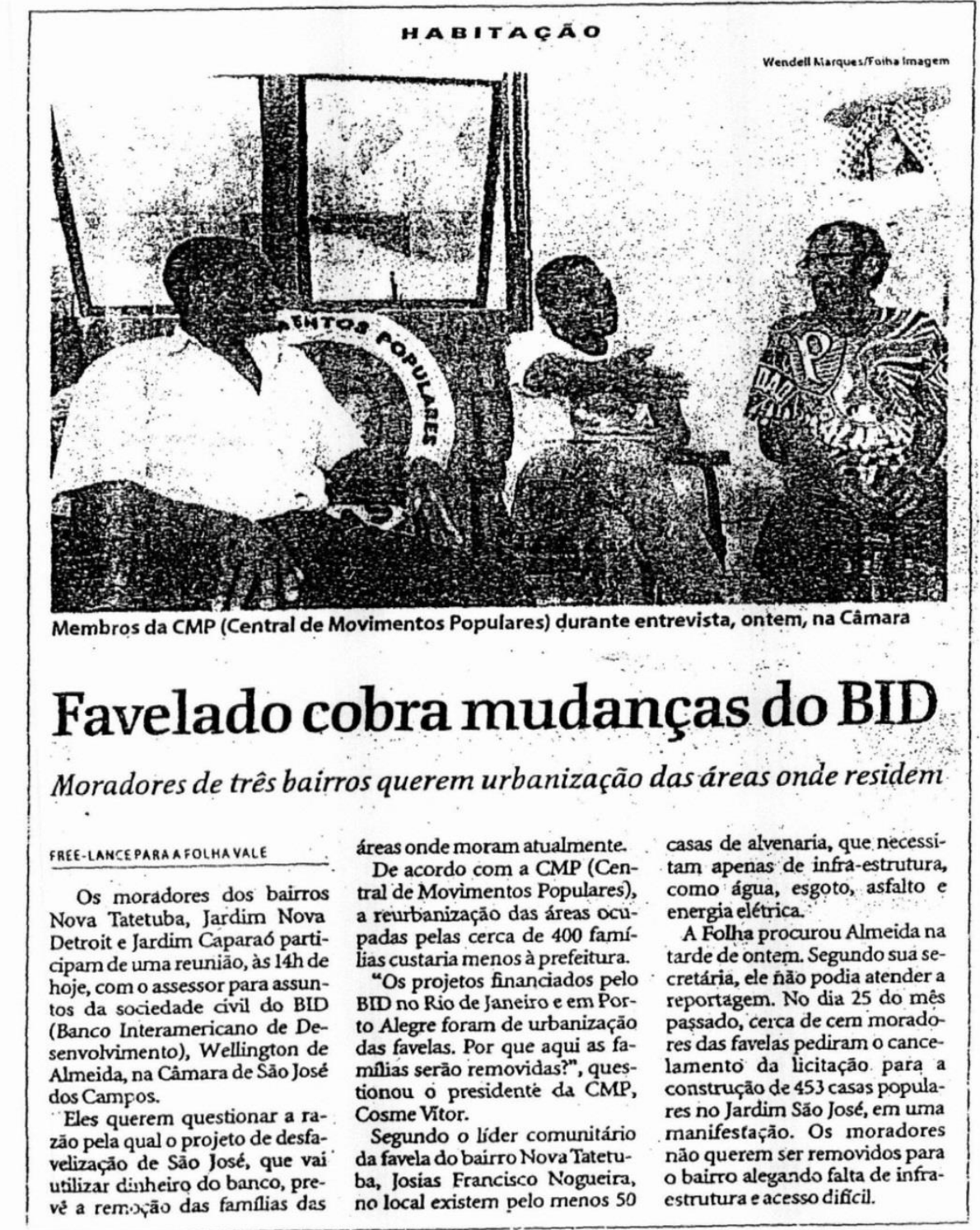

POBLADOR COBRA MUDANZAS DEL BID

Documento 3: Proposta de urbanização da comunidade foi rejeitada pelo BID. 
De acordo com as diretrizes do BID, financiador da operação urbana, necessitava-se de $80 \%$ de adesão voluntária ao programa habitacional, mas nas entrevistas com os moradores as adesões apareceram como forjadas, indo desde a pressão e falsificação até promessas de emprego no bairro novo em troca da adesão.

\section{FOLHAVALE}

IABıtTAÇÃo Prefeitura de São José dos Campos e construtora utilizam geração de 250 vagas para amenizar resistência a projeto

\section{Promessa de emprego garante desfavelização}

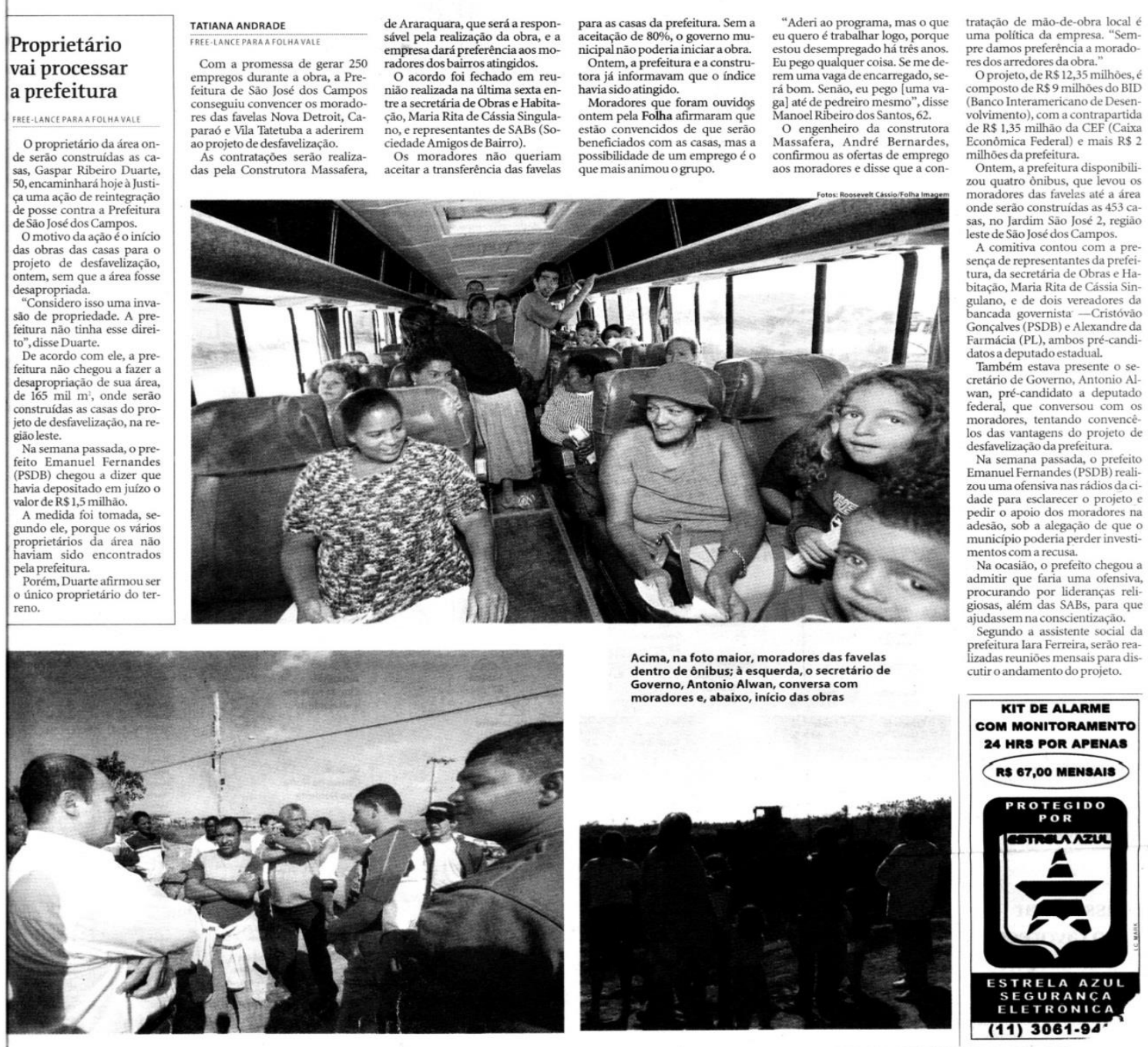




\section{FOLHAVALE}

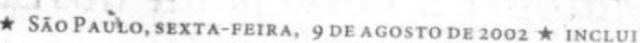

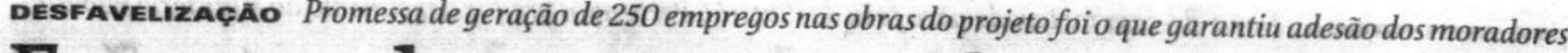 Empresa descarta moradores de favelas}
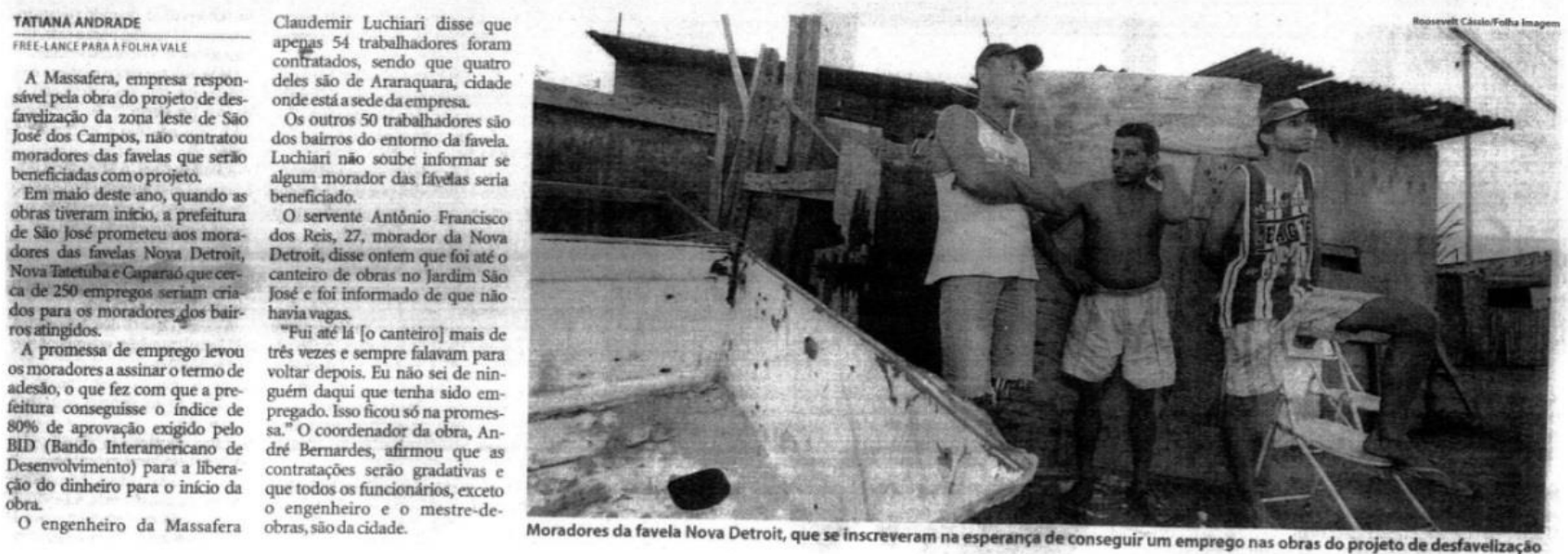

Documento 5: Cai por terra a promessa de emprego que levou muitos ao termo de adesão.

Vemos nas notícias de jornais locais que as empresas não cumpriram suas promessas de emprego. Em alguns casos, a prefeitura utilizou de outros tipos de pressão para realizar um ultimato aos moradores como forma de garantir adesão ao programa e, assim, ter acesso ao financiamento do BID. 

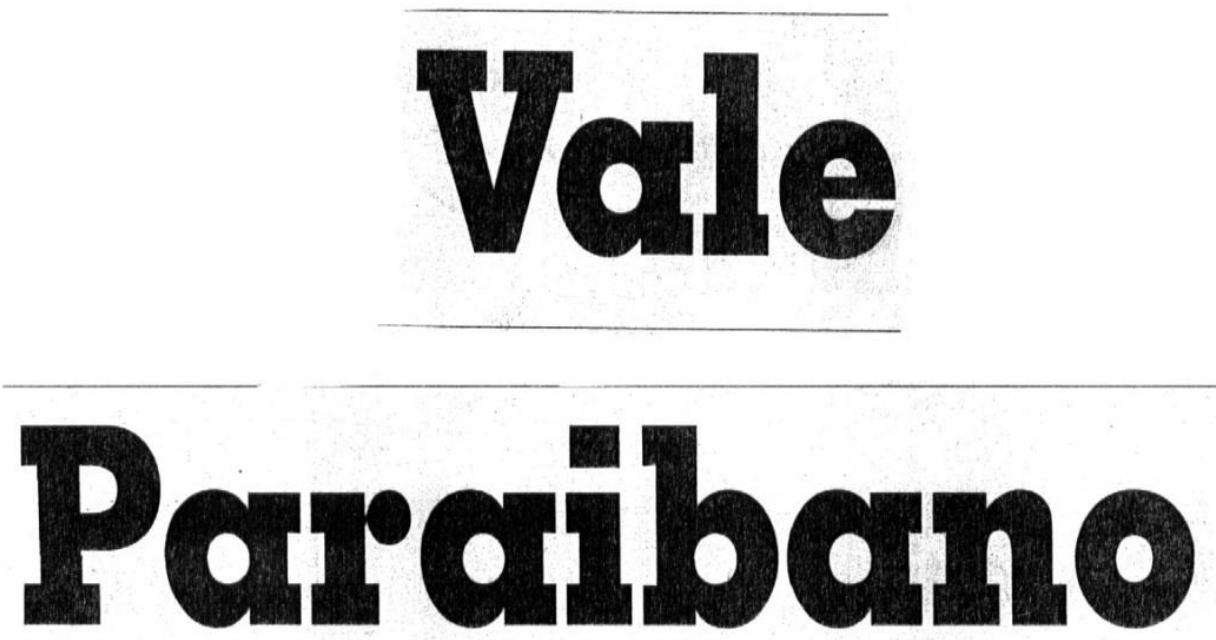

Vale do Paraíba, sábado, 18 de maio de 2002

Alcadía da ultimatióm a familias

\section{Desfavelização}

\section{Prefeitura dá ultimato a famílias}

Moradores de favelas da zona leste terão uma semana para aderir a programa

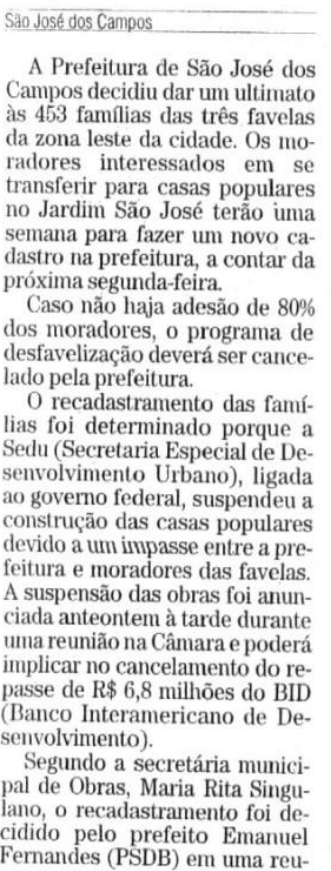
$\begin{array}{ll}\text { nião realizada anteontem à noi- } & \text { cadastramento não conseguir } \\ \text { te com representantes do BID e } & 80 \% \text { de adesão dos moradores }\end{array}$ da Sedu

O projeto tem o custo de $\mathrm{R} \$ \quad$ não haverá urbanização das fa8,5 milhões - $\mathrm{R} \$ 6,8$ milhões do BD e R\$1,7 milhão da refe tura. velas e não será escolhida outra para o projeto.

"A prefeitura não se respons

Segundo a secretária se o re bilizará mais pelos moradores",

Implantação de projeto teve início em 99

che, a escola e o Centro Comunitáriojá estiverem funcionando. Segundo ela, o local também terá água, energia elétrica e pavimentaçấo de bloquetes. $\mathrm{O}$ objetivo da prefeitura é abrir uma fábrica de bloquete que teria como funcionários os próprios moradores das favelas.

A licitaño Mara a ora ganhou Săo José dos Camipos a licitação para a obra e está aguardando a autorização da prefeitura para começar a cons-

o Programa Habitaciona Casa da Gente, que consiste na desfavelização da zona leste, faz Maria Rita disse que cada faparte do programa Habitar Bra- milia começará a pagar pela sil, do BID, e está sendo implantado em São José dos Campos desde 99.

A secretária de Obras, Maria Rita Singulano, disse que os moradores têm garantias com relação à estrutura no Jardim São José 2, pois as familias só mudarăo para as novas casas quando a casa somente após um ano da mudança para a nova área e as prestações mensais vão variar entre R\$ 15 e R\$18. 0 pagamento será feito durante 15 anos.

Cada casa, com sala, quarto. cozinha e banheiro, terá 38 me tros quadrados e seŕ construí da em um terreno de 160 metros Unidade Básica de Saúde, a cre-

0 presidente da Central de Movimentos Populares, Cosme Vitor, disse que não concordou com a nova medida da prefeitu$\mathrm{ra}$, porque representantes das famílias e da central não vão acompanhar o recadastramento Maria Rita afirmou que está descartada a negociação com :

As famílias interessadas na transferência para as casas populares deverão comparecer entre os dias 20 e 25 de maio (entre segunda-feira e sábado), das 8 às $17 \mathrm{~h}$, na sede do projeto Programa Habitacional Casa da Gente, na rua Riscala José Neme 160 , Vila Industrial, zon leste da cidade.

SUSPENSÃO -A consultora da Sedu, Kleyd Junqueira Taboada, anunciou a suspensão do projeto depois que moradores e membros da Central se declararan contra o programa de desfavelização durante a reunião na Câmara. Parte deles alegou que assinou o termo de adesão acreditando que era apenas uma lista de presença nas reuniões sobre o programa.

Kleyd determinou prazo até 31 de maio para que prefeitura moradores entrem em acordo.

$$
\text { Implantación de prajecto tuvo enicio en } 99
$$




\subsection{1. - Local da comunidade removida: o bairro Vila Industrial (1)}

Uma pequena caminhada pelo Morro do Regaço nos dava dimensão de como ali as pessoas se apropriavam da rua. Não havia um dia sequer em que as ruas não estivessem tomadas de gente. Os quintais da parte mais alta do Morro eram, em geral, grandes e permitiam reuniões familiares nos finais de semana, o que aparece de maneira saudosa em muitas entrevistas com os moradores da ocupação. Eram visíveis em frente algumas casas os carrinhos de coleta de material reciclável, dos quais muitos tiravam seu sustento diário. Muitos também trabalhavam nos residenciais do entorno e nos muitos comércios do bairro.

O bairro do qual foram removidos, a Vila Industrial (que, apesar do nome, não possui indústrias), pode ser considerado um bairro popular, pois, embora possua em locais pontuais alguns condomínios fechados de alto padrão aos arredores (caso do Residencial Planalto, exatamente em frente ao local antigo da comunidade), a maioria das casas não segue essa lógica, como é o caso os moradores do $\mathrm{BNH}$, um conjunto de casas vizinho do local da comunidade removida, ou do Conjunto Integração, um residencial de pequenos prédios a preços populares (e local onde morei a maior parte da adolescência). A proximidade até mesmo sentimental com aquele lugar foi certamente o que me mobilizou em primeira instância a escolher o tema dessa pesquisa. Acompanhei de perto a convivência com pessoas do Morro do Regaço e conheci bem o espaço do qual foram removidos, bem como todos os passos da remoção. Vejamos no mapa a localização da comunidade removida e seus entornos: 


\section{Local da Comunidade Removida (1)}
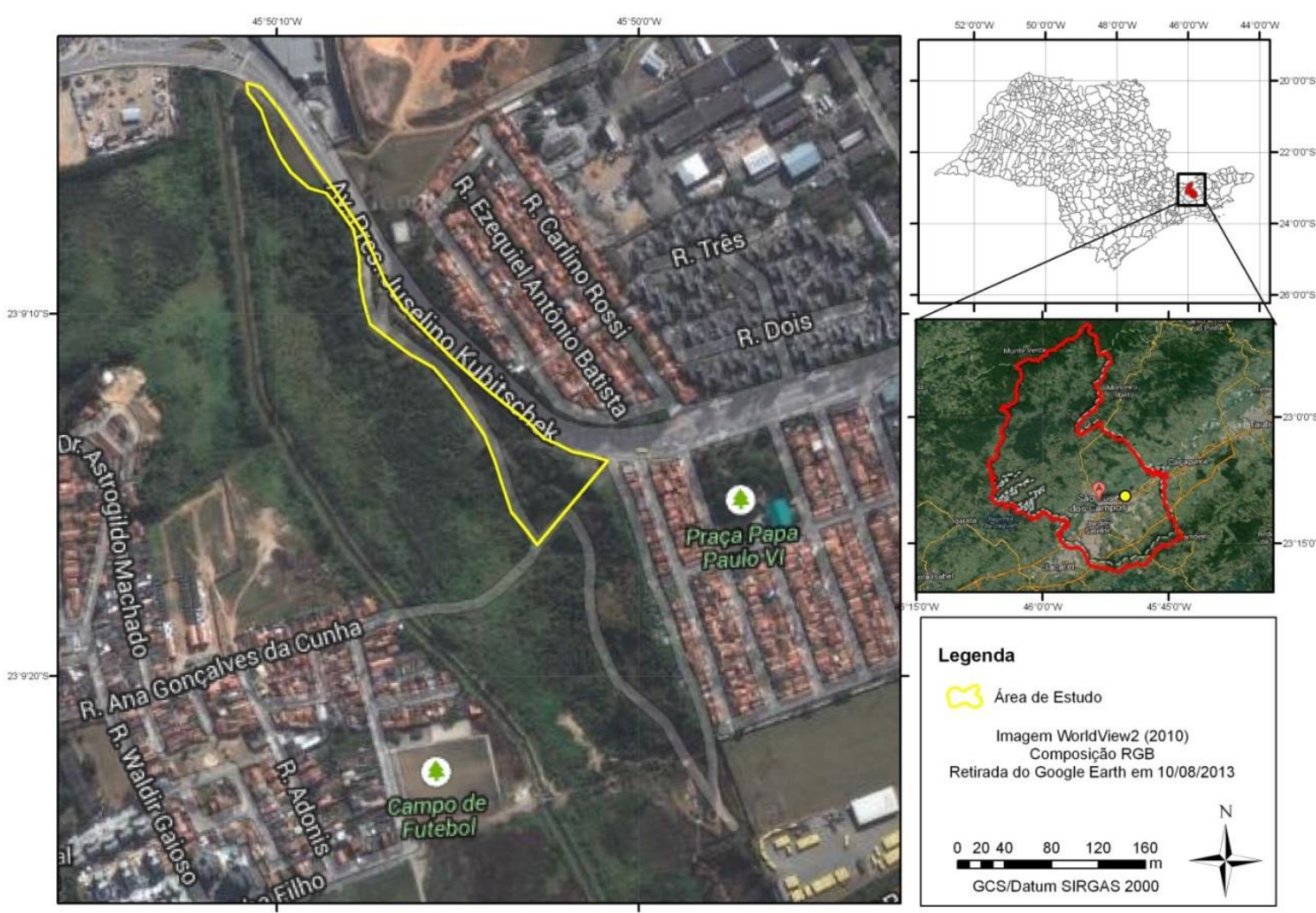

Mapa 3: Vemos nesse mapa um fragmento do bairro Vila industrial, no qual podemos ter uma visão mais clara da comunidade removida e de seus entornos.

A área de estudos, destacada em amarelo, era o local da comunidade: uma encosta inclinada limitada em seu limite sudoeste pelo córrego Cambuí, que separava a comunidade do bairro que aparece no mapa na parte sudoeste, o Jardim Jussara. Ali vemos o Campo de Futebol, local bastante frequentado por membros da comunidade, principalmente aos fins de semana.

$\mathrm{Na}$ área que ficava imediatamente em frente à comunidade, onde vemos no mapa as ruas Ezequiel Antônio Batista e Carlino Rossi, fica um condomínio fechado de casas de alto padrão cercado por altos muros e esquema de segurança rigoroso: o Residencial Planalto. Onde vemos as ruas Dois e Três, ao lado do condomínio fechado, fica o Conjunto Residencial Integração, o mais popular dos entornos e com mais moradores. Em frente ao Conjunto Integração, na parte sudeste do mapa, fica a praça Papa Paulo VI, local de encontro entre esses diferentes grupos. As casas ao redor dessa praça são conhecidas no bairro como 
BNH. A praça possui duas quadras e parque para crianças. Ela é uma referência de uso em tempo livre para os moradores da região: muitas famílias frequentam a praça aos fins de semana, levam as crianças no parque. Jovens utilizam as quadras com frequência e os bancos da praça costumam estar cheios aos fins de semana, com pessoas de todo o entorno.

Nesse espaço a convivência entre os moradores da comunidade e os demais moradores do bairro se dava de forma mais intensa, pois todos esses grupos usavam aquele espaço. Todavia, eram muito comuns em minha juventude cenas de preconceito contra a população do morro: jogos de futebol foram interrompidos diante do vislumbre distante da chegada "dos favelas", e enquanto partíamos ouvíamos a chacota deles por nosso medo manifesto. Os adultos em geral eram mais receptivos, mas claramente havia uma clivagem socialmente reconhecida que se manifestava na divisão dos times e nos grupos de conversa dos times de fora, todos sempre separando moradores do $\mathrm{BNH}$ dos moradores da comunidade.

Na parte norte do mapa, onde vemos obras na terra exposta, estão as primeiras obras para implantar empreendimentos comerciais. Toda aquela área, a princípio sem construções, foi ocupada com vários prédios de apartamentos. Na margem oposta do córrego, dois prédios de apartamentos foram rapidamente construídos e já estão em plena ocupação, enquanto no mesmo terreno se realizam obras para construção de outros dois prédios. Outros dois prédios de grande porte estão em obras quase finalizadas no terreno em frente, e toda a área próxima passa por reformulações. Esse campo de terra externo à área da comunidade era utilizado para várias funções pelos moradores da comunidade em fins de semana, cuja principal era o futebol. Agora já está plenamente ocupado por prédios de apartamentos. Isso indica um aumento nos negócios imobiliários e uma sensível verticalização.

Uma série de mudanças espaciais foi visível logo após a saída da comunidade. Um passeio pavimentado e largo foi construído, substituindo a antiga calçada usada pelos moradores da comunidade, ligando o bairro à região mais baixa, onde passa o córrego. Esse caminho foi feito contornando a antiga borda da comunidade, e em seu final temos um complexo comercial, também feito após a intervenção, cuja primeira grande empresa foi o supermercado Carrefour. Hoje, mais empreendimentos de grande porte são implementados, como duas concessionárias de veículos. Um antigo terreno da prefeitura, o chamado Teatrão, uma construção obsoleta e há muito parada, agora está se tornando um parque, o que certamente influenciará no preço dos imóveis no bairro. Obras da prefeitura recanalizaram o córrego e alargaram seu leito, gerando mais possibilidade de valorização dos terrenos do 
entorno.

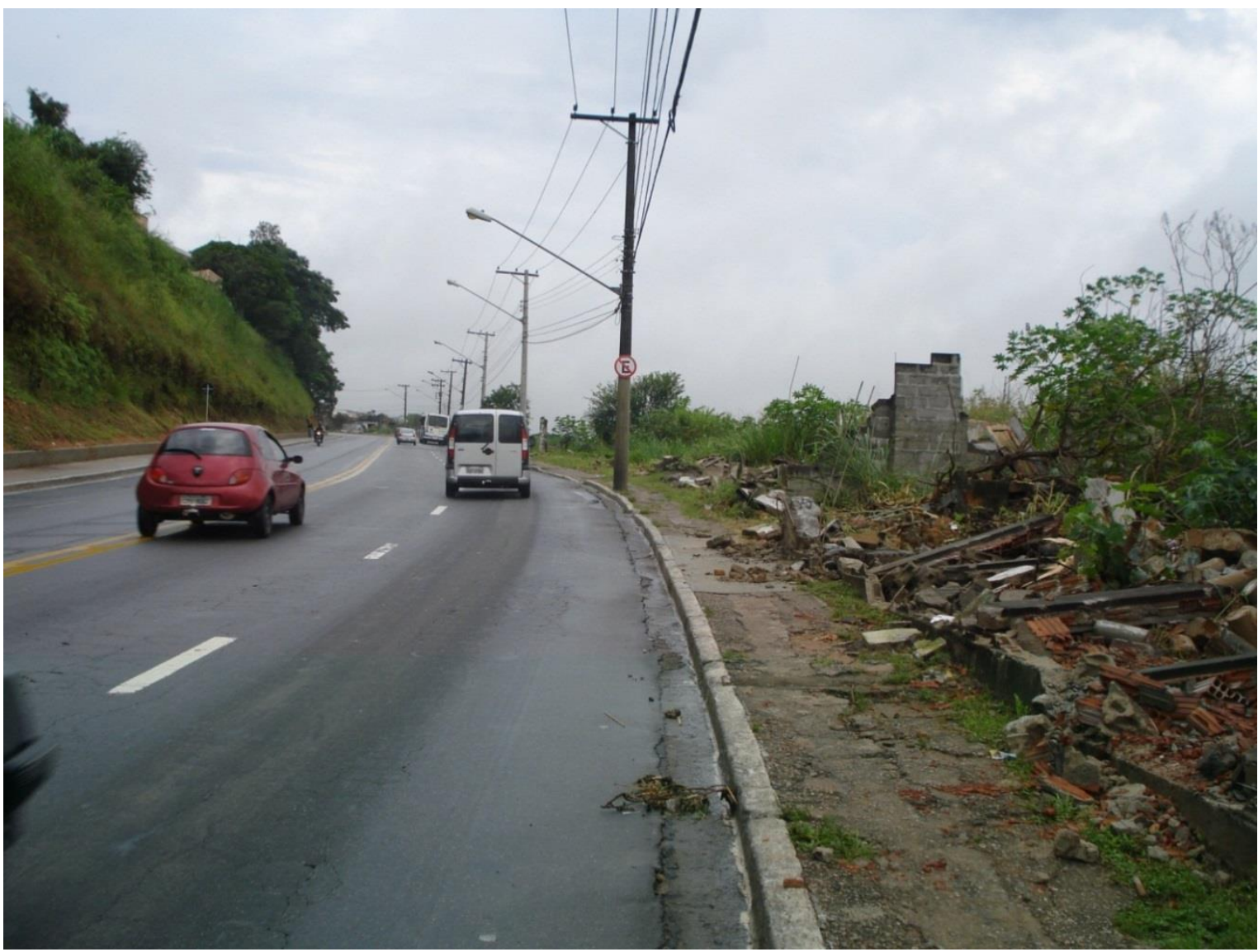

Foto 1 - À direita, o antigo passeio, na borda da comunidade removida. À esquerda, acima, o novo passeio, ligando o bairro, na parte superior, ao comércio surgido na parte inferior após a remoção.
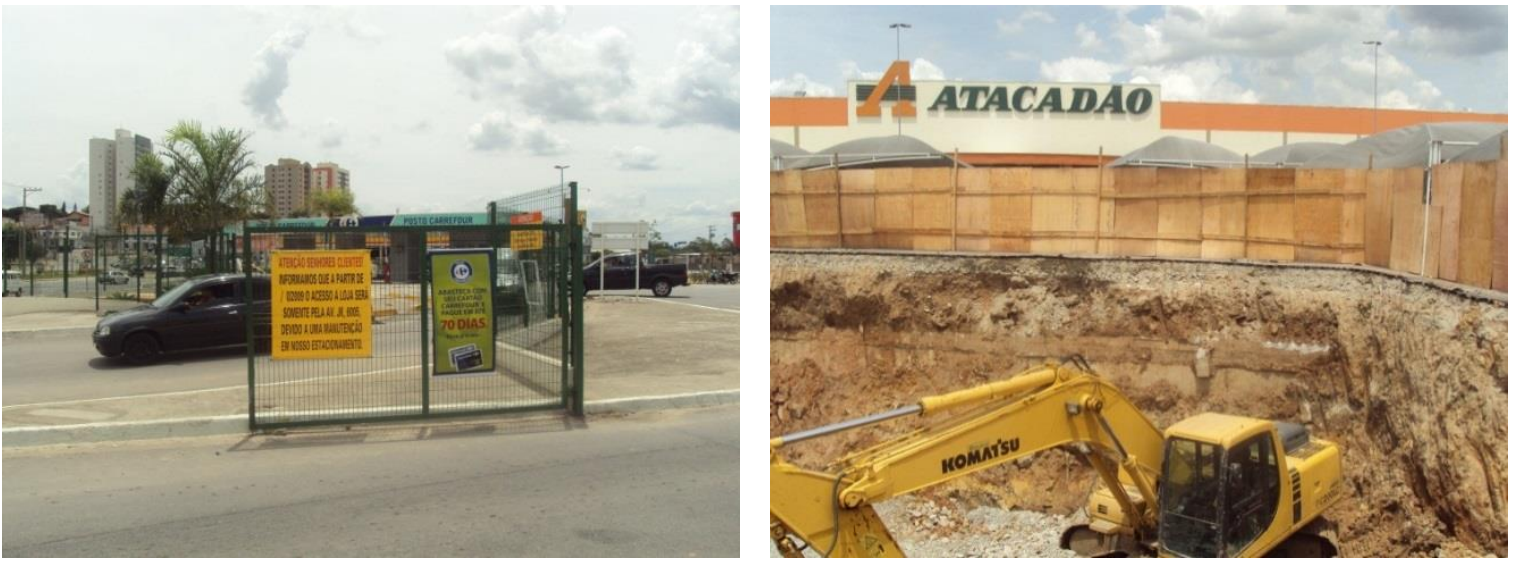

Fotos 2 e 3- Supermercado Carrefour instalado durante a remoção, sucedido no local pelo supermercado Atacadão, do mesmo grupo financeiro. As obras à direita foram financiadas pela prefeitura para corrigir a cheia do córrego Cambuí. 
A zona leste como um todo se tornou alvo de grandes negócios imobiliários e, para tanto, o poder público investiu fortemente em infraestrutura: vias de circulação na zona leste foram ampliadas e duplicadas. Há um importante cruzamento viário exatamente no local em que foram construídos esses empreendimentos comerciais de grande porte (supermercado e concessionárias, na foto acima), com vias de acesso para regiões norte e central, além das duas entradas mais importantes em direção à zona leste. Novos sistemas de viadutos também foram construídos na altura do Jardim São Vicente (bairro também vizinho de uma comunidade retirada, a Nova Detroit). Também foram duplicadas e pavimentadas várias vias de circulação de carros, tornando de maneira mais intensa o complexo comercial recéminstalado o centro de um entroncamento viário que permite o acesso entre as zonas leste, norte e o centro.

A remoção redefiniu formas de uso daquele espaço e impôs uma nova forma de acesso a ele; é essa valorização que orienta a finalidade da produção do espaço. Esse impacto é sentido inclusive pelos moradores das adjacências ${ }^{4}$ que permaneceram no bairro e sentem as "vantagens" e "desvantagens" da remoção.

Do ponto de vista dos moradores das adjacências do antigo local da comunidade, houve uma mudança drástica, vista por eles como uma melhora das condições de vida depois da remoção por não terem que conviver com o que identificavam como uma fonte de insegurança. Além disso, associam todas as mudanças positivas do bairro à remoção: logo após a saída da comunidade, a quadra da praça do BNH foi reformada e coberta pela prefeitura. Muitos moradores do bairro acreditam que isso só foi possível porque agora,

\footnotetext{
${ }^{4}$ Em um dos trabalhos de campo que fiz nessa área, ao lado de Cosme Vitor, encontramos um vendedor de capas de carro no ponto exato onde começa o bairro Vila Industrial, onde o "mato" acaba e finda um hiato de área construída. Nunca havia reparado nele, mas na entrevista ele afirmou estar ali há trinta anos, vendendo exatamente naquele ponto. Provou-se ser um informante muito observador dos processos que ocorriam nos arredores. Ele disse ter tido ótimas relações com os moradores da comunidade e contou a história da remoção sob seu ponto de vista. Diz ter visto absolutamente tudo no dia em que houve a intervenção policial. Viu o depois, como as reclamações posteriores dos moradores do $\mathrm{BNH}$, bairro residencial de classe média, vizinho à antiga comunidade, sobre a ocorrência de cobras e outros bichos nas casas, o que não acontecia quando a encosta era ocupada. Viu os prédios caros surgirem no antigo campo de futebol, os hipermercados e as reformas nas pistas dos carros. $\mathrm{O}$ vendedor e Cosme Vitor apontavam para as áreas baixas, nos vales dos córregos, e indicavam o que seria feito no plano para novas avenidas naquela região. O novo acesso para Vila Industrial, segundo eles, passaria exatamente por aquele ponto, e até mesmo algumas casas do BNH serão afetadas, e já teriam até sido contatadas para a compra. No fim da conversa, um casal carregando um bebê surgiu do que parecia ser uma pequena trilha pelo mato. Uma casa, no topo do morro, bem no fundo, não foi afetada pela remoção, pois ali a distância do rio era muito grande e a declividade era pequena demais e não houve argumento para retirá-los. Eles conheciam Cosme Vitor e o vendedor, pararam para conversar. Cosme ofereceu carona, eles aceitaram. Conversando com eles, vi que ainda temem ser removidos, pois identificam estarem no caminho dos novos planos rodoviários da cidade e de alguma forma sentem não ser mais o "perfil" dos moradores ali.
} 
apenas as pessoas que sabem cuidar bem do espaço poderão utilizá-lo, deixando implícita a relação feita entre morador de comunidade e uma pessoa "naturalmente" descuidada para com espaço público. Contudo, algumas famílias mais pobres da região da praça já sentem a diferença nos preços dos produtos no comércio local e uma mudança no padrão do morador do bairro, o que é visto por eles como negativo.

De um lado, a remoção realizou a retirada dos "indesejáveis" e potencialmente "perigosos" - o que nos leva a pesar o papel do imaginário social construído em torno da comunidade, fundado em preconceitos sociais evidentes: associação com crime, violência, drogas, território sem leis onde domina a imoralidade. Por outro lado, o bairro passou a ficar mais caro e o novo padrão não pode ser acompanhado por todos igualmente.

\subsection{2. - A ocupação no centro: a estação de trem (2)}

Após a remoção, moradores que não aderiram ao projeto ocuparam a antiga estação de trem no centro da cidade. Essa ocupação foi feita no dia 25 de janeiro de 2004 e durou até o ano de 2016, quando os moradores conquistaram casas da prefeitura em um bairro próximo ao local de onde foram removidos quando ainda estavam na comunidade.

A articulação política das lutas na ocupação logo envolveu o movimento pela habitação e moradia, e houve a constituição de um corpo político de lideranças internas aos moradores, além de externas, principalmente vinculados ao PT. O papel da Comissão de Movimentos Populares foi importante nesse momento de necessidade de experiência na militância reivindicativa, além de consolidar significativas experiências de politização que ocorreriam por meio do contato com outros movimentos organizados como o MST e a Conlutas. A figura de Cosme Vitor, da CMP e do PT, era central na personificação de uma liderança durante a luta para evitar a remoção, ainda na comunidade. O papel da CMP, e principalmente de Cosme Vitor, é posto pelos ocupantes como decisivo na construção do movimento de resistência à remoção. A descoberta do espaço da estação e de sua situação legal (terreno da União sem uso, perfeito do ponto de vista de uma ocupação) foi feita por ele, o que viabilizou a ação de ocupar. Durante o período de ocupação, seu papel de liderança articulada aos habitantes da ocupação era importante. Mesmo hoje, após a conquista da casa 
pelos membros da ocupação, ele ainda os visita e tenta utilizar seus contatos políticos para ajudá-los da forma que pode, ainda sendo visto como um tipo de liderança entre eles.

Vários atos e manifestações já partiram da ocupação ou terminaram nela. Além disso, houve a incorporação em sua luta dos moradores presentes em outras mobilizações pela cidade, em especial no que concerne à habitação popular, como foi o famoso caso do Pinheirinho: moradores da ocupação estavam presentes naquela que ficou conhecida como a remoção mais violenta de São José dos Campos. Sua atuação somou-se a luta geral por moradia em São José dos Campos.

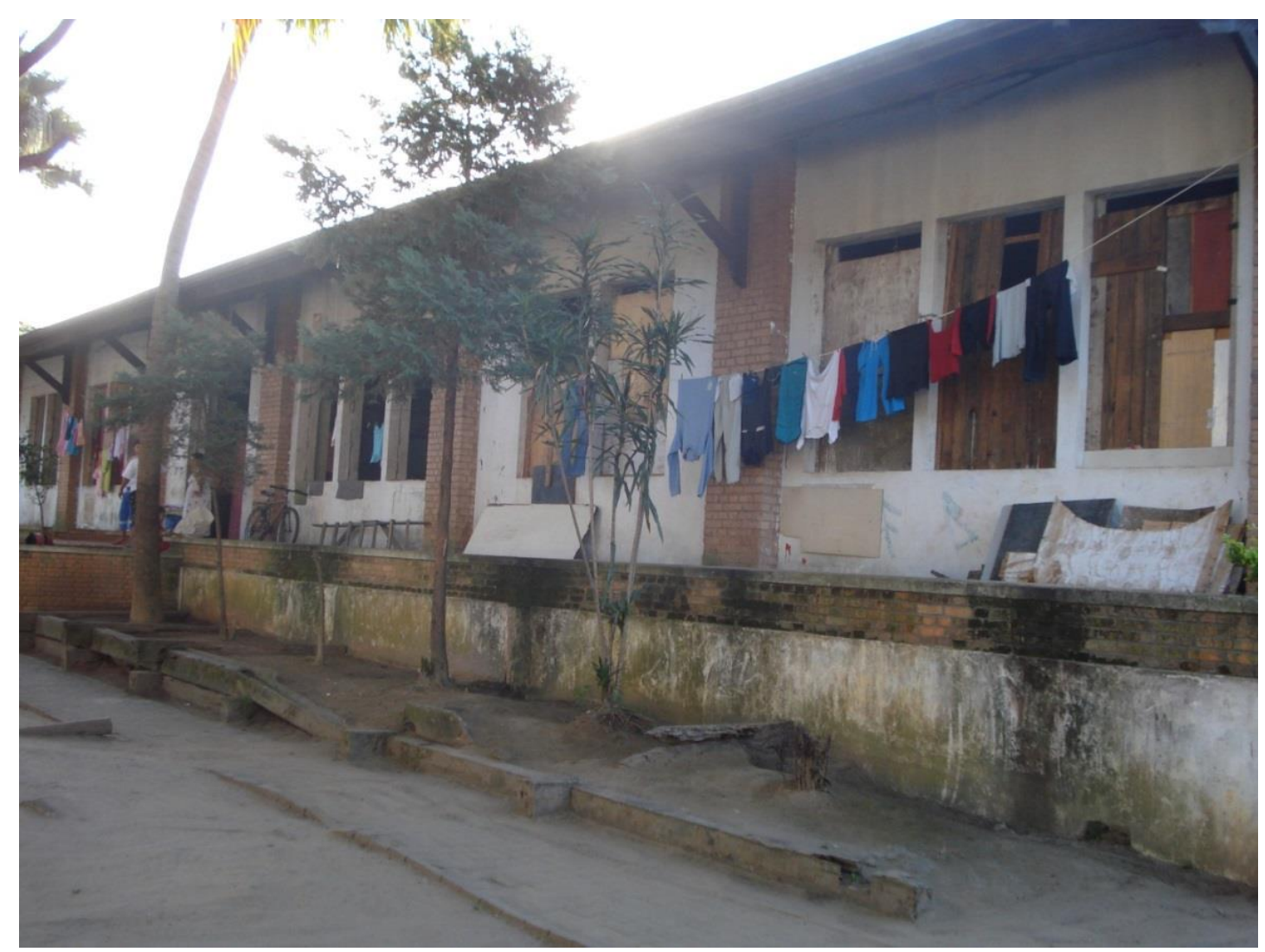

Foto 4 - Vista interna da ocupação da antiga estação de trem. 


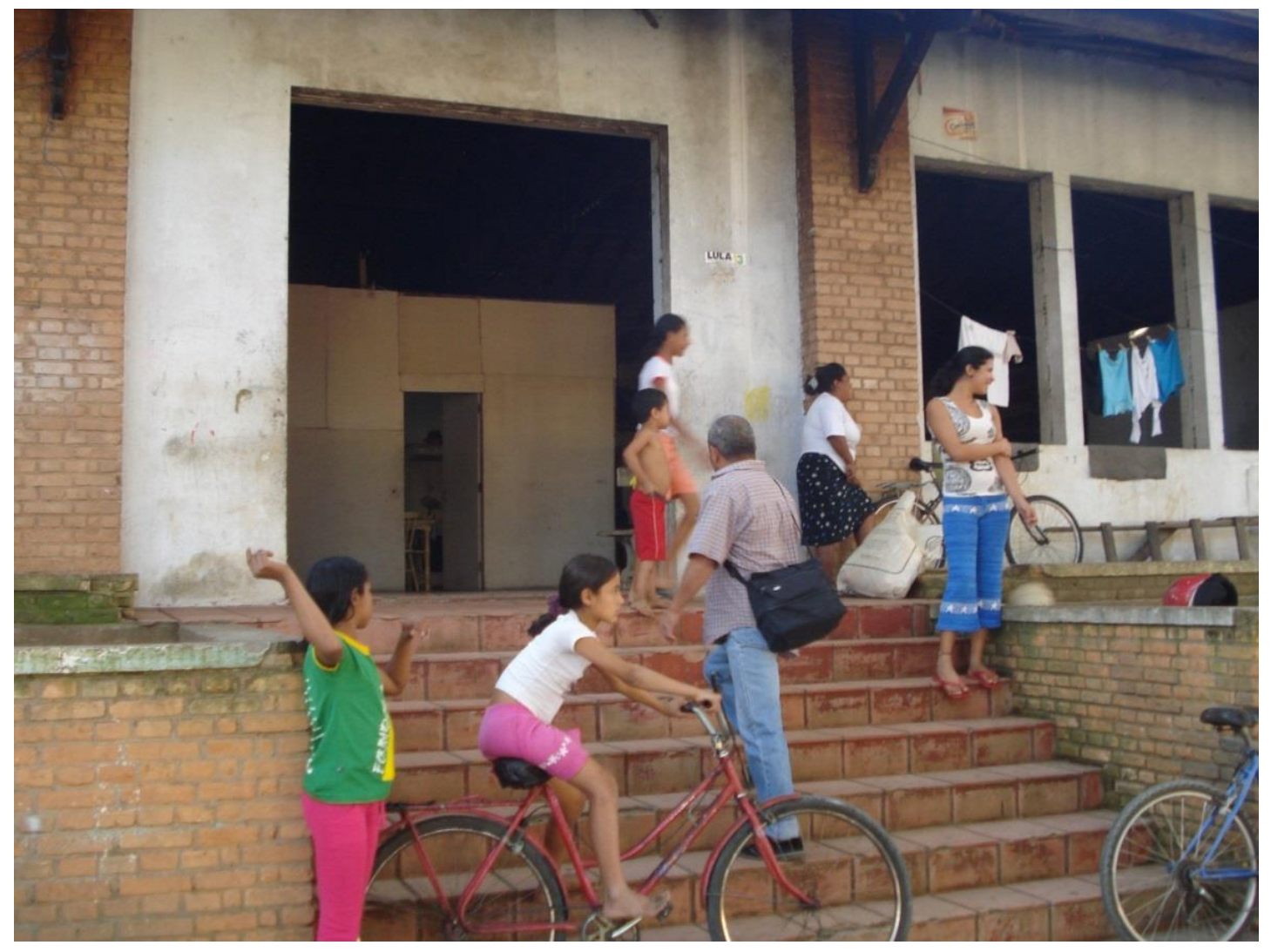

Foto 5 - Entrada principal da ocupação. Ao fundo, no espaço interno, vemos as divisórias das casas, feitas de madeira.

Passando por um grande portão duplo que separava a ocupação de uma rua movimentada do centro, havia um amplo espaço público interno semelhante a um grande quintal, com árvores e boas sombras, além de um pátio que permitia grande entrada de sol, o que gerava uma área de convivência bastante grande. Em um dos prédios da antiga estação, vi o que seriam "sacadas" ocupadas por mulheres conversando, muitas crianças brincando no grande quintal, alguns jovens ouviam som alto em um carro "invocado" no pátio, e muitas cadeiras foram postas para fora pelos moradores.

Ao adentrar a ocupação, a sensação transmitida foi de alguma carência estrutural, pois aquele espaço não fora destinado a ser moradia. As casas eram bem diferentes umas das outras, mas em geral eram em espaços interiores grandes subdivididos por tapumes de madeira. As dimensões das casas eram pequenas, mas não muito diferentes do encontrado por mim no bairro novo para onde foram os demais removidos, o Jardim São José II.

Em termos de acesso à infraestrutura urbana, pode-se dizer que estavam em posição extremamente boa: eles moravam literalmente ao lado do Parque da Cidade, uma excelente 
opção de lazer que atrai pessoas da cidade toda, pois o parque é uma bela área verde com pistas de corrida, trilhas, campos de futebol, quadras, além de ser local de realização dos mais diversos eventos gratuitos da cidade, como festivais de teatro e música; próximos de várias escolas, de uma sede da FUNDHAS e do SENAI; acesso a praticamente todas as linhas de transporte urbano, uma vez que quase todas desembocam no centro; acesso ao comércio mais diversificado da cidade, localizado no centro velho e nos arredores do mercado municipal; além de próximos de maiores possibilidades de trabalho.

Mesmo estando bem localizados em sua condição de centralidade, era flagrante nas falas dos moradores que uma série de laços de sociabilidade e de trajetos cotidianos foi modificada com a mudança de local de moradia, e é exatamente o tipo de perda que não pode ser aferida ou mensurada, mas precisa ser destacada. Mesmo não tendo aderido ao programa, os ocupantes tiveram uma drástica mudança do seu cotidiano: desenraizamento do lugar da vida e a perda desse referencial identitário com o lugar.

Por um lado, viveram as experiências de pico da prática política, a resistência e transgressão constantes. Por outro, sentiram a perda dos contatos de amizade no antigo bairro, muitas mudanças de local de trabalho, um novo espaço do habitar (na realidade, improvisado). A entrevistada Sra. Nalva ressaltou em seu relato os aspectos mentais da remoção: o trauma, a dor da perda material, de tudo que haviam conquistado com esforço, a violência a que foram submetidos. Ela trata um problema de depressão desde 2007 e vinculao totalmente à desfavelização. Portanto, traçar um quadro geral da violência a que foram submetidos esses moradores é no mínimo difícil, considerando as diversas esferas da vida que foram afetadas.

Quanto ao cotidiano da ocupação, a vida determinava-se pela persistência. Após o ato de ocupar segue-se o de continuar ocupando, uma resistência contínua. A maioria das questões presentes no cotidiano da ocupação eram relativas a infraestrutura, como a divisão do espaço entre as famílias, problemas com a falta de água, etc. Outras eram de cunho organizacional, como as questões de segurança, por exemplo. Eram todas resolvidas em reuniões e, quando necessário, pelo voto direto, embora se buscasse sempre um consenso. Além dessas questões pontuais, discutiam-se também suas pautas maiores e maneiras de levá-las adiante. Suas decisões eram todas coletivas, baseadas em reuniões constantes para decidir desde questões pontuais até bandeiras políticas. A comparação feita pelos moradores com outros movimentos organizados ao descrever sua organização é notória, principalmente com o MST. O cenário de politização e formação política era bastante favorecido. 
A pauta sobre a questão das moradias e ocupações ganhou força na década subsequente, e desenhou-se uma cena política na qual o papel dos ocupantes da estação de trem mostrou-se como uma das forças atuantes de forma relevante. A principal pauta política da ocupação foi uma longa luta pelo reconhecimento público da violência empreendida na desfavelização. Uma série de denúncias foi feita junto ao Banco (BID). O BID ainda investiga a documentação protocolada pela ocupação em sua ouvidoria, e muitos emissários já foram enviados para dialogar com as lideranças. Houve um conjunto de ações da parte dos membros da ocupação na tentativa de divulgar depoimentos e fotos da remoção, em todos os espaços possíveis: universidades, eventos, atos, espaços de outros coletivos sociais, além da divulgação em todo tipo de fórum, órgãos da imprensa e nas ruas.

Além dessa reivindicação, lutavam também, evidentemente, por moradias dignas e bem localizadas, como as que tinham antes da desfavelização, além da restituição de bens destruídos na remoção ou que se perderam nos galpões da prefeitura.

Outra reivindicação tratava das famílias nascidas dentro da ocupação. Algumas crianças e adolescentes que moravam com os pais na época da remoção hoje têm por volta de trinta anos, alguns pretendem constituir família em breve e outros já o fizeram. Algumas crianças já nasceram moradoras da ocupação. As famílias novas eram prontamente incluídas na pauta, indicando um agravamento do problema. Além disso, o espaço da ocupação era muito restrito e não permitia uma expansão maior do que as 22 famílias que já estavam lá, o que havia sido a fonte de problemas a serem contornados pelos moradores. Essa pauta gerou uma divisão interna no movimento entre a liderança interna, principalmente na pessoa do senhor Deomar, e a liderança externa de Cosme Vitor. O poder municipal negociou por anos com os ocupantes. Estes não aceitavam, segundo as falas dos próprios moradores, nada menos do que uma casa digna e bem localizada, no máximo $5 \mathrm{~km}$ do local da ocupação, por ser exatamente o que perderam. Essa postura guiou toda a discussão em torno das propostas da prefeitura, e muitas foram recusadas. Quando a prefeitura ofereceu a casa nova, na qual estão os moradores da ocupação hoje, não incluíram na proposta os moradores jovens. Deomar quis aceitar a proposta, mas Cosme Vitor não, pois almeja continuar a luta para alcançar uma conquista mais ampla. Houve um embate político e o lado que apoiava a conquista imediata da casa venceu, decidindo-se deixar o espaço da ocupação ${ }^{5}$.

\footnotetext{
${ }^{5}$ Fiz um trabalho de campo, após o fim da ocupação, para o espaço onde ela se localizava e para as casas novas conquistadas pela ocupação, acompanhado de Cosme Vitor. Cosme me mostrou o espaço da ocupação sendo reformado e dividido em salas menores. Coletivos atuantes na periferia, a maioria de arte, utilizam as salas ali e compartilham o grande salão comum e os banheiros. Lá fora, no caminho para o salão principal, vi uma pequena marcenaria aparentemente em uso constante, produzindo para móveis e madeiramento para a reforma.
} 
No trabalho de campo, em visita às casas novas, um ano após a conquista, vi que ainda se menciona essa questão, motivo de certa tensão entre Cosme e Deomar. Porém, ainda continuam próximos e aliados políticos. De certa forma, Cosme parece ter visto essa posição como "o fim da luta" de certa maneira, agora que "cada um toca sua casa por conta própria".

\subsection{3. - As casas conquistadas (3)}

A rua das novas casas localiza-se na borda do bairro Vila Industrial, com vistas para a linha de trem (uma área ainda sem uso imobiliário na cidade). É nessa mesma linha de trem, na parte onde ela cruza o centro, que ficava a ocupação. Os arredores da antiga linha de trem criaram espaços "vazios" que agora estão, aos poucos, sendo incorporados à cidade. Do outro lado da rua estão visíveis os trabalhos de preparação do terreno para a construção de um campinho.

\footnotetext{
No salão principal, vi uma pequena biblioteca e materiais dos coletivos de arte. No anexo desse salão estão dois cômodos menores, estes bem reformados e pintados, com banheiro próprio, mas ainda vazios. Ali se planeja fazer um museu da ocupação, que conte a história daquele lugar e do movimento que ali lutou. Percebi que o plano é manter o espaço em uso, permitir a apropriação por diversos coletivos, realizar festivais e atividades para a população. Cosme sempre utilizava as palavras no plural e referia-se a um sujeito abstrato "nós", mas pude identificar que esse "nós" não eram os antigos membros da ocupação. Eles de alguma forma ainda mantêm alguma relação com esse espaço, mas o uso majoritário dos dias de hoje está nas mãos de diversos grupos menores que não são financiados pelo poder municipal e bancam de seus próprios recursos as melhorias do espaço. $\mathrm{O}$ aspecto ainda é de um lugar em ruínas, mas algumas salas comportam uso. Haverá um longo processo de reforma até todo o espaço poder ter uso pleno e efetivo, mas o potencial de tamanho e a vantagem locacional são enormes.
} 


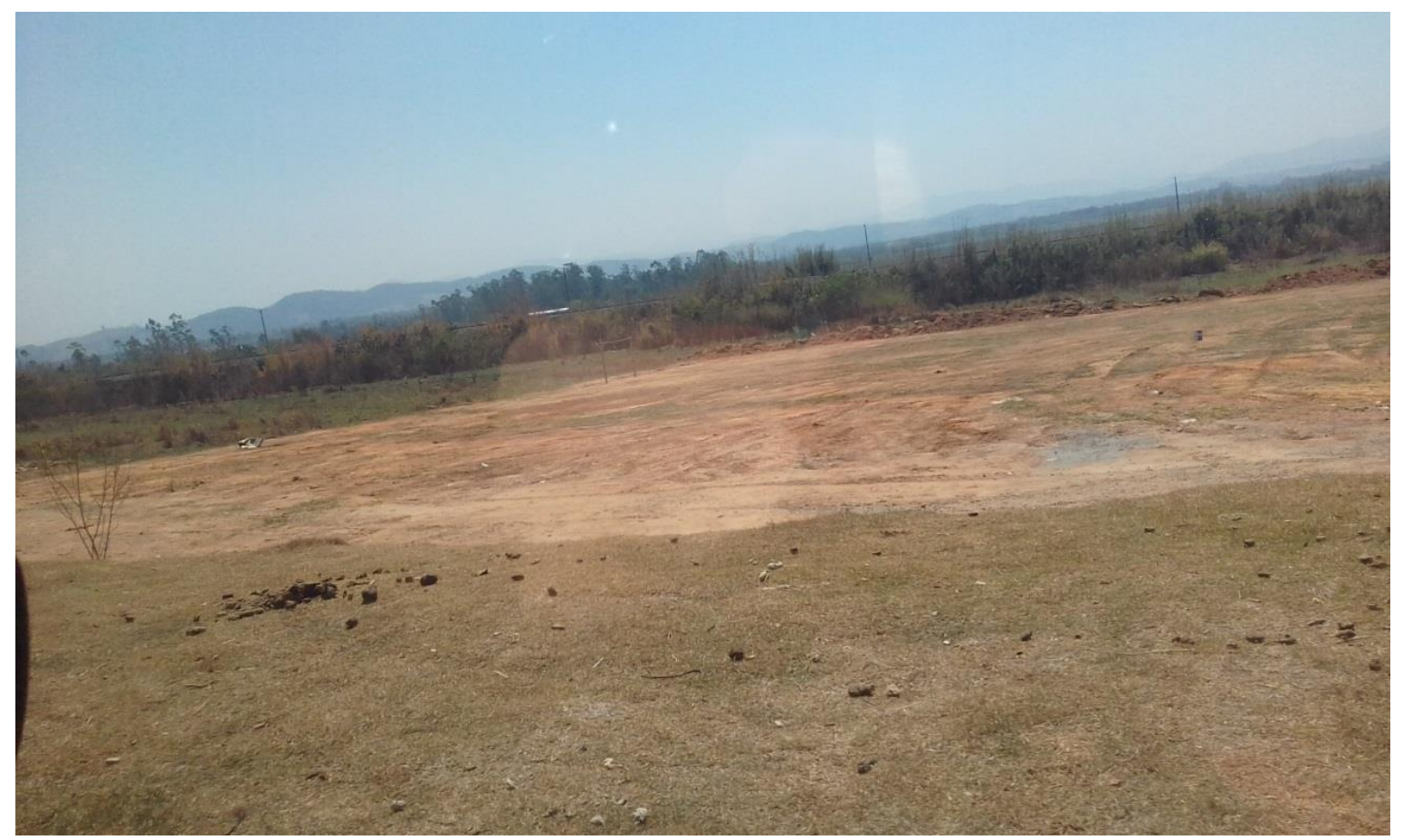

Foto 6: Terreno preparado para ser um campo de futebol, em frente às casas conquistadas pela ocupação. Na primeira elevação do terreno, ao fundo onde começa a vegetação, passa a linha de trem. No ponto em que essa linha atravessa o centro ficava a ocupação.

Nesse trabalho de campo, quase todas as casas da rua estavam em obras. Os moradores estavam ali há um ano, mas ainda faziam modificações no traçado original das casas como uma forma de dar-lhes identidade. Entre as garagens das casas não havia muros no projeto original, mas eles agora os erguiam. Além dos muros, algumas casas também colocavam portões de ferro, o que evidencia uma preocupação com questões de segurança e com uma privacidade maior. Cosme era crítico dos muros, achava que os dividia sem necessidade. $\mathrm{Na}$ fachada das casas os muros laterais e frontais ainda estavam recentes e sem acabamento. 


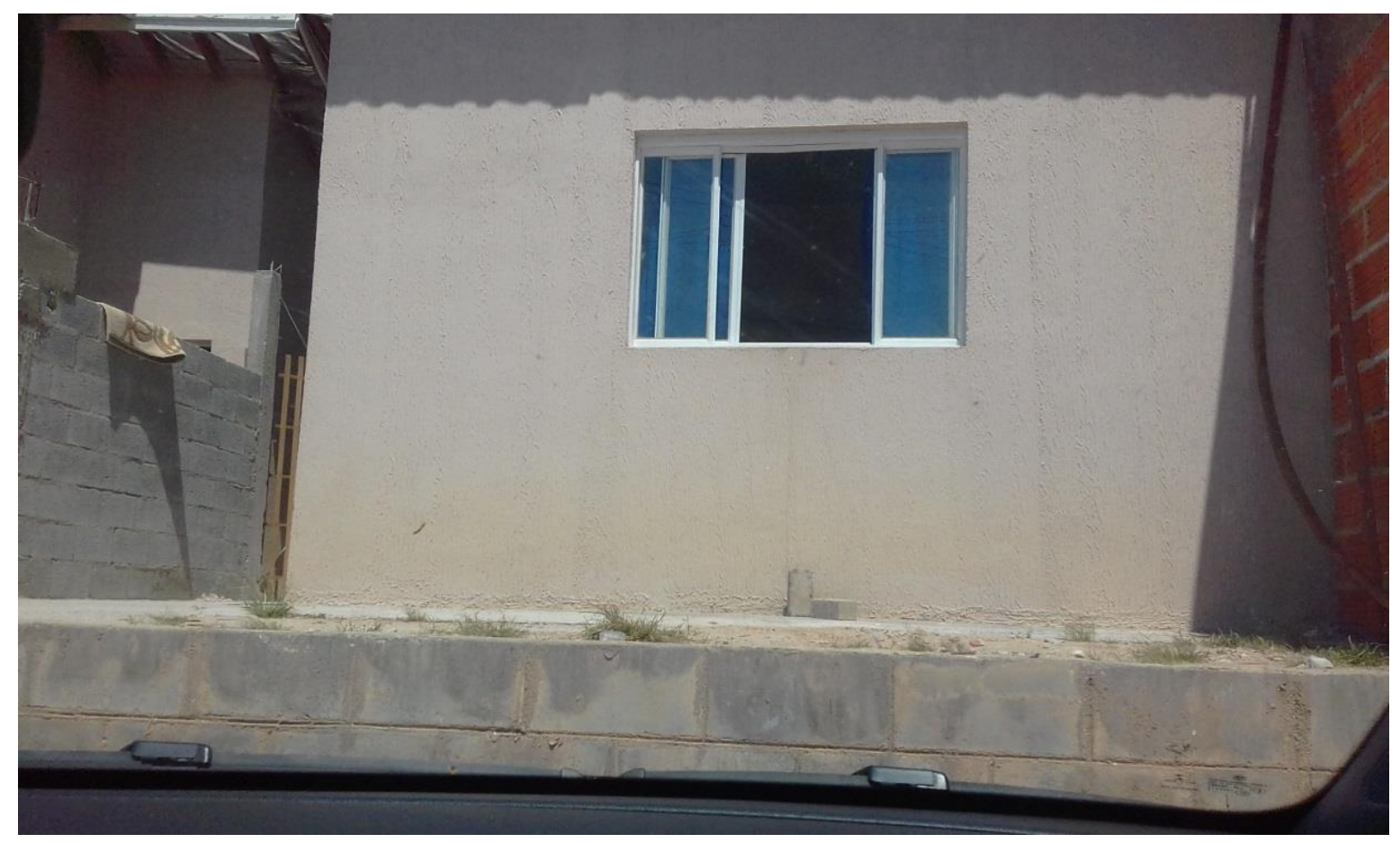

Foto 7: Vista frontal da casa nova conquistada pelos moradores da antiga ocupação. Nas laterais, a construção de novos muros não existentes no projeto original.

No último trabalho de campo nas casas novas, feito na companhia de Cosme Vitor, visitamos algumas casas e conversamos com algumas famílias ${ }^{6}$. Falamos, entre outras coisas, sobre o processo de confecção do campinho de futebol em frente às casas. Houve uma mobilização entre os moradores, que se reuniram para fazer as obras necessárias. De acordo com eles, dar um uso ao local impediria a prática de jogar lixo naquele terreno como, segundo contaram os vizinhos, já se fazia há tempos. O processo coletivo para construção ${ }^{7}$ acabou envolvendo outras pessoas do bairro, pois já está estabelecida uma diferenciação entre "nós" e "eles", entre os moradores antigos do bairro e os oriundos da ocupação. Apesar do campinho coletivo, a relação ainda parece envolver conflitos, preconceitos e discriminação, uma vez que houveram relatos de falas preconceituosas em comércios do bairro, dirigidas aos novos moradores, por parte de outros moradores das ruas vizinhas. De

\footnotetext{
${ }^{6} \mathrm{Na}$ primeira casa, fomos recebidos na sala, buscaram água gelada. Eram uma mãe, a filha casada e o marido da filha. Falaram sobre problemas de saúde da mãe e como Cosme poderia ajuda-los. A casa era pequena, parecia bem acabada e eles a todo tempo exaltavam a felicidade de estar ali. Cosme e os moradores pareciam se conhecer bem, próximos e bem relacionados. A todo tempo faziam menção ao seu grupo como um coletivo que ainda decidia ações em conjunto, que se movia para realizar atividades próprias e já haviam se inserido na realidade política de seu bairro novo. Uma das novas conquistas era o campinho de futebol.

${ }^{7}$ Cosme mencionou como ele poderia ter sido contatado e ajudado a conseguir recursos da prefeitura para acelerar a construção, mas os moradores preferiram fazer por conta própria, sem ajuda. Ele se queixou, meio sério e meio de brincadeira, que já não era mais consultado e solicitado para as ações do grupo.
} 
acordo com algumas moradoras oriundas da ocupação: "as vizinhas da rua de cima não se misturam".

O campinho agora passou de terreno de despejo de lixo e entulho para um espaço público movimentado. Destarte, ele se tornou o lugar da reunião dos diferentes. Ele é uma fonte de encontros e entre os que jogam bola já se construíram alguns laços. Mesmo com essas relações, fica evidente uma divisão clara entre grupos distintos, entre os "antigos" moradores e os "novos". O preconceito dirigido aos "novos" moradores contrapõe-se ao sentido do que é o público como união do diferente. Ainda assim, o fato de ser um espaço fruto da ação coletiva de moradores "antigos" e "novos" reúne esses grupos diferentes e nos dá alguma dimensão da importância que esse espaço recém criado terá no cotidiano do bairro.

Um dos planos que ouvi serem feitos para esse campinho é uma grande festa das crianças no feriado de outubro ${ }^{8}$, pois a quantidade de filhos ali é alta. Todo o processo organizativo para a festa no campinho envolverá reuniões e participações de todos. Tudo indica que os moradores da ocupação ainda se veem como um grupo que atua coletivamente. Houve até um relato, durante minha visita, sobre um membro desse grupo que de alguma forma prejudicou o coletivo e foi dele banido, sendo impedido por eles de se mudar para a nova rua. Isso indica que se veem como um grupo e possuem um código de conduta compartilhado segundo o qual todos devem proceder.

Nesse campo, visitamos o senhor Deomar e sua esposa Nalva ${ }^{9}$. Deomar era uma liderança forte entre os moradores, mesmo nas casas novas, e sua relação com Cosme parecia ser a mais próxima de todas. Fomos recebidos nos fundos da casa, onde pude observar que eles construíram uma churrasqueira, um balcão grande, uma mesa espaçosa, com acabamento nas paredes, uma área propícia para se receber a família, como eles um dia haviam me declarado ser sua maior vontade. Nalva, depressiva na época da ocupação, parecia radiante. Comparando o espaço das duas casas deles, fica evidente a melhora qualitativa significativa na residência. Essa era uma das casas mais modificadas em relação ao projeto original, pois o senhor Demoar trabalha com construção civil.

\footnotetext{
${ }^{8} \mathrm{Na}$ rua, mulheres com várias crianças pararam Cosme e conversaram um pouco. Ele conhecia a todos por nome. Falaram da festa das crianças e sobre o campinho. Já surgem planos entre as mulheres de usar o espaço sobrando nas bordas do campo para uma quadra de vôlei, com areia, e uns bancos de praça para os mais idosos.

${ }^{9}$ Eu já os havia entrevistado quando ainda eram moradores da ocupação.
} 
Foi minha mais longa conversa ${ }^{10}$ entre todas as entrevistas para essa pesquisa. Deomar contou que pagarão por alguns anos uma quantia quase simbólica de $\mathrm{R} \$ 25,00$ por mês pelas casas. Estão ali há cerca de um ano e parecem bem felizes com o resultado de sua luta. Contudo, houve o conflito no processo de saída da estação de trem, no centro, entre os poucos que desejavam continuar a ocupação e ampliar as conquistas, lado defendido por Cosme, e os muitos que desejavam aceitar a nova casa e findar a ocupação, lado defendido por Deomar. Esse assunto voltou várias vezes ${ }^{11}$.

Na primeira entrevista, Deomar contou-me o quanto gostava de receber familiares no quintal da casa na comunidade, na ocupação isso se tornou mais difícil. Agora eles têm um espaço perfeito para isso e já em uso. Esse é de longe o espaço mais decorado e cuidado da casa. Além dos familiares, os vizinhos aparecem sempre, como de fato aconteceu durante nossa conversa. Outras pessoas passaram por ali e participavam da conversa, como o filho de Deomar. Nalva, sua esposa, contou-me na última entrevista de seus problemas com depressão. Não sei em que medida ela ainda passa por isso, mas nada foi falado nesse sentido $^{12}$.

A análise dos desfechos desse processo de lutas permitirá uma aproximação maior e melhor dos conteúdos do processo de resistência à urbanização. A conquista da casa após a ocupação muda de novo o conteúdo da resistência. O que representou para eles a conquista da casa? O fim da luta? Eles voltaram às mesmas práticas e formas de consciência de antes? Como a atuação deles na nova moradia revela desfechos dessa experiência com movimentos sociais? Mais adiante, trataremos destas questões.

\footnotetext{
${ }^{10}$ Deomar me perguntou sem rodeios: “amarela ou branca?". Não entendi. Ele repetiu: "amarela ou branca?", em um tom que admitia poucas discussões. Escolhi amarela. Ele pôs dois garrafões de cinco litros sobre o balcão, um com cachaça amarela e outro com cachaça branca. Tirou dois copos de dose, serviu duas amarelas, virou seu copo em menos de um segundo e estendeu o meu, enquanto me olhava fixamente. Parecia um "teste". Virei o copo. Ele suspirou: "estava me perguntando se ia ou não virar esse copo...". Depois disso a conversa fluiu naturalmente e por um longo período (tenho minhas dúvidas sobre a abertura dele durante a conversa caso eu tivesse recusado sua oferta). Foi minha maior conversa do dia, durou horas.

${ }^{11}$ Durante as histórias que contavam, percebi que haviam entrado em conflito sério sobre essa pauta. Algumas vezes ao longo da conversa, senti quase um tom de reconciliação entre os dois, enquanto brindavam copos de cerveja. Deomar presenteou Cosme com um peixe grande congelado. Ficamos ali uma hora e meia a mais do que o planejado, adiando compromissos de Cosme com hora marcada. Houveram episódios esporádicos de discordância, mas sempre pouco enfáticos e cheios de sorrisos, mas implicitamente senti um ar relativamente tenso.

${ }^{12}$ Conforme minha coordenação motora diminuía, fui causando pequenos acidentes pela cozinha, o que me deu oportunidade de conversar mais com ela, aos risos. Ela estava bem e radiante. Quando fomos embora da casa, já estava no quintal um clima de festa, com a presença dos vizinhos que iam chegando. Tivemos uma despedida afetuosa.
} 


\subsection{4. - O bairro novo: Jardim São José II (4)}

O bairro novo Jardim São José II, ou "Cidade de Deus", como ficou apelidado, foi construído na borda leste da cidade ${ }^{13}$. Lá foram alocados moradores das três primeiras comunidades removidas no programa de desfavelização, além de uma pequena parcela de pessoas beneficiadas por programas habitacionais como CDHU.

Em termos de infraestrutura urbana, os moradores contam com uma UBS, uma escola de ensino fundamental (EMEF Prof. ${ }^{a}$ Rosa Tomita) e uma sede da Fundação Hélio Augusto de Souza (FUNDHAS), mas eles claramente passam a sensação de não se sentirem contemplados em termos de serviços públicos, principalmente quanto à qualidade do atendimento, pois sentem que médicos e professores "não os tratam da mesma forma que tratam as outras pessoas na cidade”. A principal queixa é sem dúvida quanto à insuficiência do transporte público para lá, pois os ônibus são lotados e demorados. As casas também são vistas por muitos como deficitárias em dimensão e qualidade de construção. Os que tiveram condições financeiras reformaram a casa, e ainda é uma visão comum nas ruas o ambiente de reforma em muitas moradias.

Nada em termos de construções urbanas existia nos arredores desse bairro, e seus contornos eram circundados por fazendas e suas pastagens (observando o mapa 1, podemos perceber a cor verde como predominante nos arredores). Essa condição era vista na fala dos moradores como "morar na roça". A paisagem dos entornos caracterizava para os moradores o fim da morfologia clássica identificada por eles como cidade, dando força nas falas deles

\footnotetext{
${ }^{13}$ As primeiras impressões sobre o bairro novo Jardim São José II começaram ainda no centro da cidade, enquanto eu aguardava o ônibus para realizar meu primeiro trabalho de campo. Esperei no ponto por um longo tempo (cerca de 50 minutos) e com isso pude constatar que poucos ônibus fazem aquela linha. Enquanto aguardava, vi uma garota que podia pegar qualquer ônibus daquele ponto, ela desceria em um lugar próximo e qualquer ônibus da cor verde a deixaria no local correto. Ela deu sinal quando viu um ônibus verde à distância, mas desistiu de pegá-lo assim que percebeu ser o Jardim São José II. A cena foi tão perceptível que o cobrador falou alto ao motorista: "só não subiu porque era 'CDD', ficou com medo e pegou o de trás", ao passo que o motorista respondeu: "ninguém gosta de pegar ônibus com favelado". Disseram tudo no mais alto e bom tom, diante de todos os passageiros que enchiam os assentos. Independente das motivações reais da garota, a forma como isso apareceu no ônibus já é reveladora do preconceito com que os moradores têm que lidar diariamente. O restante da cidade, principalmente nas imediações, ainda se referem a eles como "favelados", embora tecnicamente o novo bairro não seja uma favela, suas casas sejam de alvenaria e suas ruas asfaltadas. Essa primeira cena mostrou-me a representação que se fazia do bairro, e antes mesmo que eu o conhecesse meu imaginário ficou povoado de sensações das quais tentei ao máximo escapar. Cronometrei o percurso do centro até o bairro: uma hora e quarenta e cinco minutos de movimento, considerando que era um fim de semana, com menos trânsito e menos paradas pelo trajeto. Todas as minhas visitas tiveram que ser realizadas em fins de semana.
} 
para a ideia de separação da cidade, percebida por eles. Contudo, a construção do novo bairro possibilitou, em anos posteriores, o surgimento de bairros recentes e ainda mais distantes, para os quais ele agora é também uma via de acesso. Ele ainda é cercado de pastagens, mas agora dele parte uma estrada que dá acesso a outros dois bairros.

Após a construção das vias de acesso aos bairros ainda mais distantes, surgiu um mercado novo e maior no Jardim São José II. Soube que minha mãe, moradora dos bairros mais recentes, aqueles ainda mais distantes surgidos após a construção do bairro novo para os removidos, frequenta esse mercado apesar da distância, pois segundo ela é o mais barato que conhece. Ele apareceu como uma solução para consumo de baixo custo uma vez que, quando não existia o mercado até certo tempo atrás, opções de compra no bairro eram escassas e a cidade era longe. Uma das principais queixas no meu primeiro trabalho de campo ao bairro era justamente a ausência de comércios e mercados, o que encarecia os custos de alimentação.

Pensando em termos morfológicos, até mesmo os espaços coletivos do bairro, como a praça central com pista de skate, não funcionam como centralidade. Em todos os trabalhos de campos ${ }^{14}$, nunca observei nenhum grupo de jovens utilizando a praça como local de encontro, em horários diferentes e dias diferentes da semana. Jovens entrevistados afirmaram não gostar de ir lá. Parece que a centralidade pensada por um planejador sobre uma folha de papel em branco nem sempre se traduz em realidade quando os planos são trazidos à realidade. Essa centralidade abstrata não foi capaz de se firmar como local de reunião e encontro. Campos de futebol abertos em terreno alheio nas fazendas dos arredores parecem cumprir mais essa função do que a praça central.

A primeira constatação durante o primeiro trabalho de campo no bairro novo foi a ausência de pessoas na rua. Já visitei muitas comunidades pelo Brasil e todas elas tinham em comum uma maneira marcante de apropriação do espaço da rua por parte dos moradores, e mesmo em bairros pobres de periferia essa característica pode por vezes ser bastante expressiva. Era um fim de semana e, embora as ruas não estivessem totalmente desertas, nem de longe se assemelhavam ao movimento esperado por mim. Para conseguirmos explicar, ao menos parcialmente, essa ausência de pessoas nas ruas e espaços públicos do bairro, podemos mencionar a disposição espacial na forma como foram distribuídos os moradores, que não levou em conta as origens diferentes de cada um. Moradores de uma

\footnotetext{
${ }^{14} \mathrm{E}$ mais as incontáveis vezes que precisei cruzar o bairro, já que ele recentemente se tornou via de acesso para bairros ainda mais distantes, um dos quais abriga a casa de minha mãe.
} 
mesma comunidade foram colocados em pontos distantes, separados por várias ruas. Muitos laços de sociabilidade e vizinhança se perderam com essa simples e aparentemente pequena mudança. Outra consequência, mais grave, desdobrou-se dessa condição: o que seria um sentimento de união na comunidade, uma base comum a todos, a ideia de unidade da comunidade, foi aos poucos dissolvida e deu lugar a disputas menores, como rivalidades entre grupos de jovens que se hostilizam pelo olhar ou mesmo com palavras. Isso construiu entre eles uma nova divisão social que não permitiu a constituição de uma identidade de bairro, de pauta reivindicatória comum, de lutas ou mesmo de vizinhança. A identidade marcava o discurso nas antigas comunidades, o que os aglutinava em torno da resistência contra a remoção. Ela deu lugar a rivalidades entre moradores oriundos de comunidades diferentes e a disputas internas, pois vemos uma clara separação entre "nós" e "eles" na fala de alguns moradores. Nos primeiros meses de convivência, abriu margem até mesmo para disputas entre grupos rivais ligados ao tráfico que antes eram separados espacialmente, o que resultou em muitos assassinatos. Essa distinção aparece até mesmo nas falas. Na casa de meus parentes, era bem comum fazerem uma diferenciação ao anunciarem que estavam ali pela CDHU e que não eram "favelados", assim como toda a rua era composta de pessoas que conseguiram a casa pela CDHU, o que lhes dava também vizinhos não "favelados"15. Embora morassem no mesmo bairro e fossem, por isso, tão segregados quanto seus vizinhos, viam a segregação como algo legítimo e que não os envolvia da mesma forma. Como nos diz Pádua (2015b: 91); “os que sofrem a segregação, muitas vezes reproduzem as ideologias que os segregam", o que traz como consequência a desunião pela falta de consciência da sua condição.

\footnotetext{
${ }^{15} \mathrm{~A}$ sociabilidade que eu esperava encontrar nas ruas, ao menos foi vista parcialmente dentro de uma casa. As moradias da rua da CDHU possuem um pequeno quintal na parte de trás da casa, voltado para o limite "rural" do bairro. Uma lona havia sido colocada no chão e era molhada constantemente com uma mangueira e com o barro dos pés das crianças e adolescentes que ali brincavam de escorregar pelo declive do terreno. Era uma reunião com as crianças das casas vizinhas. A mãe da família relatou que não gosta muito de deixar seus filhos brincarem nas ruas do bairro por medo "das companhias", mas que isso acaba sendo inevitável, principalmente pelo convívio escolar que acaba aproximando as crianças.
} 


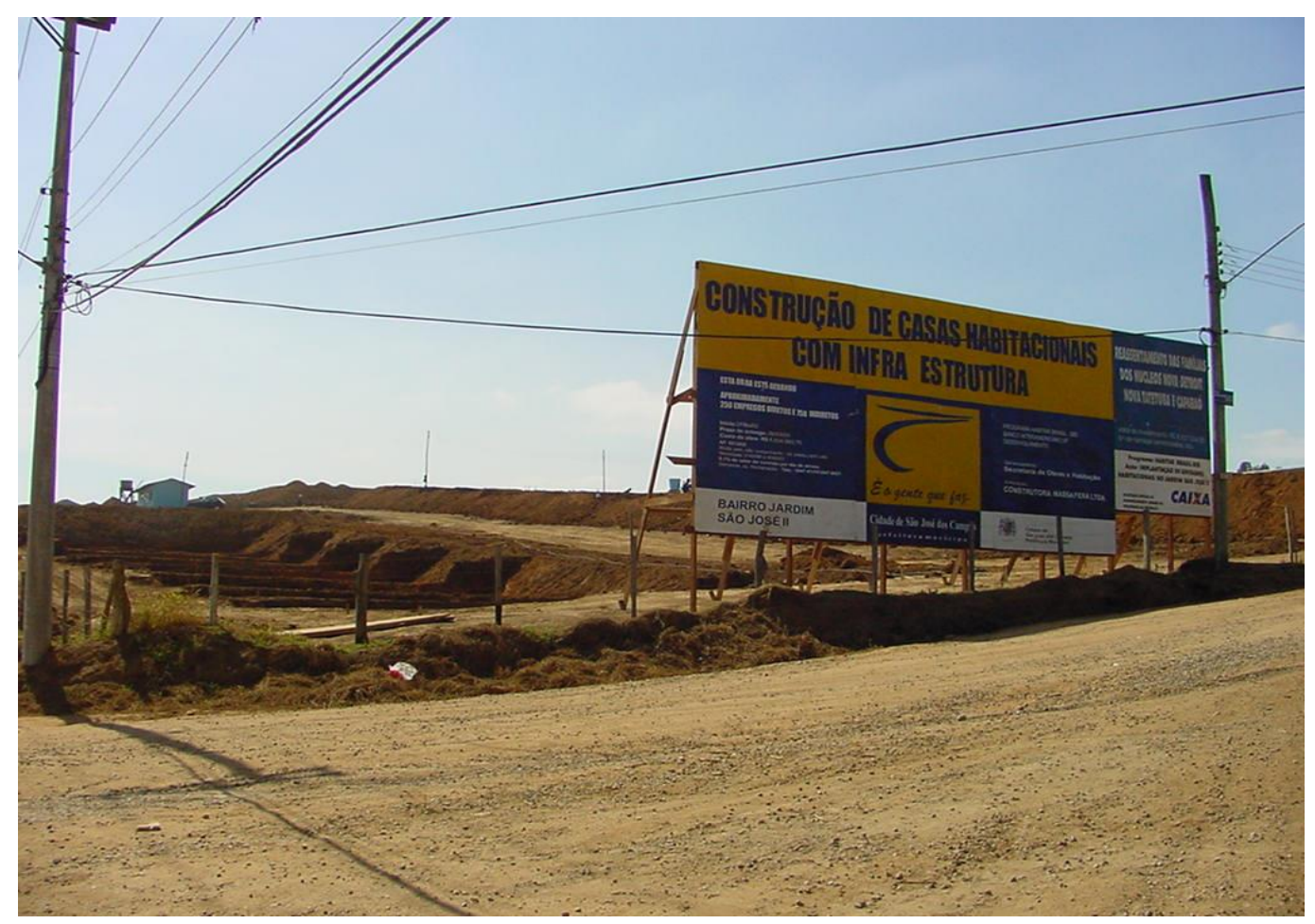

Foto 8 - Início das obras do bairro novo Jardim São José II.

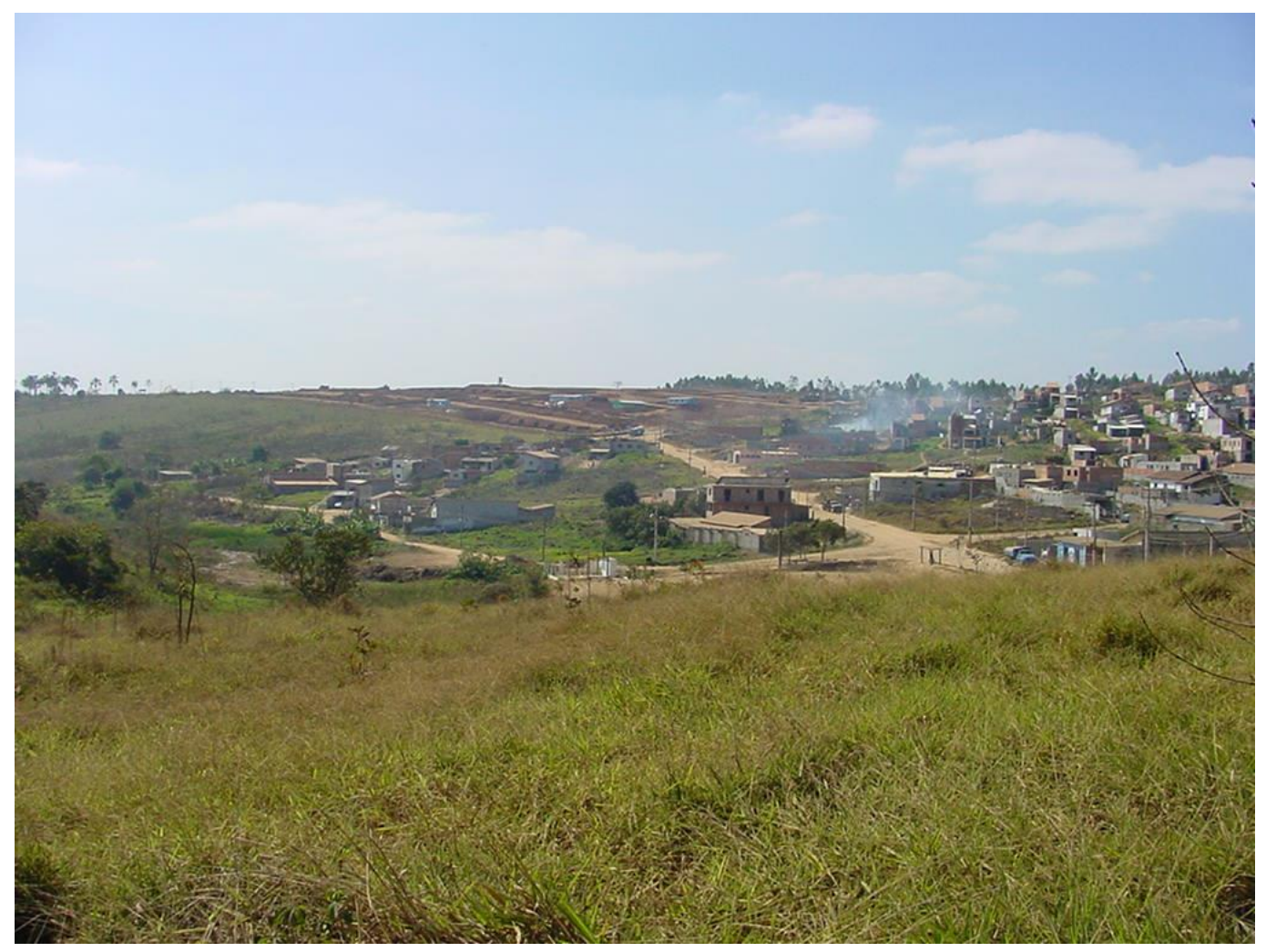

Foto 9 - Centralizado e ao fundo, na linha do horizonte, as obras do bairro novo. 
A sensação de afastamento e separação do resto da cidade é muito clara entre os moradores. Frequentemente utilizam-se da palavra "isolados" para descreverem sua atual condição. Embora o tempo e a distância sejam grandes empecilhos, algumas dessas medidas são sociais e tornam-se mais importantes para aferir a dificuldade de mobilidade. A barreira financeira do deslocamento é, para muitos, intransponível, principalmente pensando-se em um passeio no fim-de-semana com toda a família. A solução encontrada é geralmente permanecer no bairro nos momentos de lazer. Passeios no que seria uma "área de natureza" nas pastagens dos arredores são comuns. Na tarde do meu trabalho de campo, pude constatar mais pessoas fazendo seu passeio "pela natureza", em geral levando seus animais de estimação. Nas pastagens, muitos cavalos, bois e outros animais dominam a paisagem. Nos arredores, vi também um pedaço de fazenda apropriado por um campo de futebol. Em uma de minhas idas ao bairro, apenas ele era um espaço público que estava em uso.

A barreira do preconceito também é esmagadora. Brasil (2013) nos mostra em entrevistas como algumas moradoras do bairro, todas empregadas domésticas, perdiam oportunidades de emprego ao darem seus endereços aos empregadores. As oportunidades de renda também ficaram restritas para uma grande parcela de trabalhadores da reciclagem. Nas áreas centrais, era mais simples e mais rentável a atividade dos catadores de material reciclável. Distantes das zonas de coleta e venda, é inviável levar uma carroça de material por todo o caminho e retornar para casa, mesmo com auxílio de cavalos.

Muitos jovens do bairro abandonam estudos, principalmente pela distância das escolas de ensino médio. A falta de opções em educação e lazer acaba por agravar o problema da criminalidade entre os jovens. A violência entre os jovens tornou-se um quadro dramático já nos primeiros meses de convivência no bairro novo. Segundo Brasil $(2013,56)$ :

O fenômeno da violência enquanto criminalidade foi muito intenso no início, na formação do bairro. Logo que as pessoas foram removidas das três favelas para o Jardim São José II, houve o que já era previsto: a disputa pela hegemonia do tráfico. As três favelas não eram vizinhas, nem sequer próximas umas das outras, ficavam em três bairros diferentes da zona leste, cada uma tinha uma facção que comercializava as drogas. Quando todos foram removidos para o mesmo bairro, houve uma violenta disputa pelo domínio do tráfico, o que resultou no assassinato de muitos jovens.

Ele, em outro trecho, faz um relato ainda mais esclarecedor: 
O fenômeno da violência pareceu afetar de uma forma muito importante a vida cotidiana desses moradores. Absolutamente todos entrevistados relataram ter familiares envolvidos em episódios de violência sofrida e/ou envolvimento com a criminalidade, tais como ameaças de morte (e por isso serem obrigados a se mudar do bairro, ou até mesmo de estado), assassinatos (sofridos e cometidos), filhos e parentes presos por assalto, assassinato e envolvimento com tráfico de drogas. Além disso, episódios como toque de recolher e lista de pessoas do bairro que seriam assassinadas em épocas determinadas, como por exemplo, no natal, também marcaram presença nas falas dos entrevistados. (Brasil, 2013, 62)

A violência sentida no novo bairro aparece nas falas dos moradores de maneira constante. Além dos conflitos entre os grupos rivais, outra marca forte de violência aparece na presença constante da polícia no bairro. Muitos relatos de truculência policial surgem nas entrevistas.

Em outro trabalho de campo feito por mim ao lado de Cosme Vitor, pude ter um pequeno acesso ao cotidiano do novo bairro e suas dificuldades ${ }^{16}$ na esfera da violência. Ao chegarmos, fomos na casa da primeira moradora. Fomos recebidos na garagem. Ela nos trouxe água gelada e três cadeiras. Parecia ser jovem, no máximo quarenta e poucos anos, era moradora da comunidade Nova Detroit. Pessoas da família passavam o tempo todo; a neta dela, com no máximo dois anos, brincava ao nosso redor. Em um canto, estava uma cruz de madeira ao lado de sacos de latinhas de alumínio.

\footnotetext{
${ }^{16}$ No caminho para o Jardim São José II, Cosme me perguntou se eu estava com meus documentos na mochila. Estranhei. Ele contou que era constantemente parado pela polícia na entrada do bairro, pois sabiam quem ele era, e criavam dificuldades extras sem motivo. De alguma forma, o discurso dele contra a violência policial o tornou um alvo.
} 


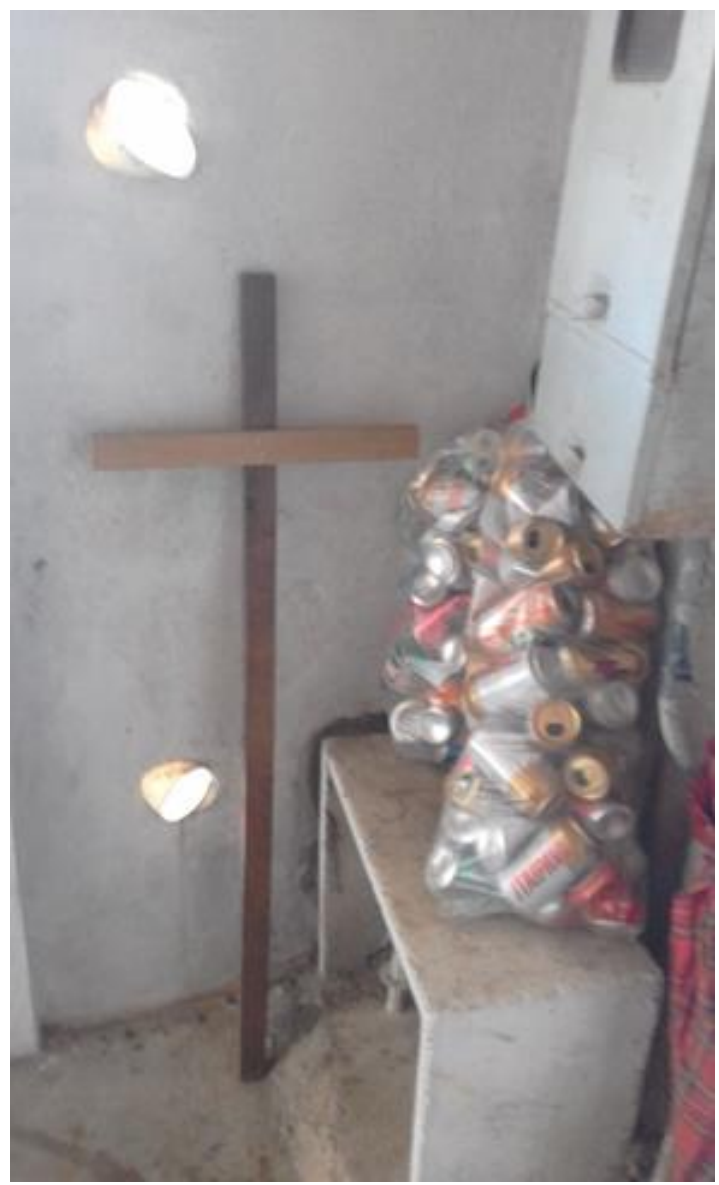

Foto 10: Cruz de madeira a ser colocada no local do assassinato do filho da moradora do Jardim São José II.

Cosme já estava inteirado do assunto. Ela contou que o filho dela estava envolvido com o tráfico de drogas no bairro quando foi pego por policiais em uma emboscada e levado até uma fazenda nas cercanias, um lugar isolado e escuro. $\mathrm{O}$ garoto gritou por ajuda, o que foi ouvido por moradores que se dirigiram para o local, incluindo o pai dele. Não houve tempo, o jovem foi executado ali mesmo. Isso acontecera quatro dias antes de nossa visita. Ela narrou tudo sem derramar uma lágrima. Demonstrava ter uma força impressionante para lidar com isso. Ela mencionou que esse jovem tinha poucos anos na época da remoção, e ela estava muito relutante em ir para o bairro novo.

Ela agora batalha por justiça, quer exumar o corpo do filho, refazer exames, gastar tudo o que tiver com advogados para obter a versão verdadeira do assassinato do filho. Dali três dias faria uma semana do caso, e ela pretendia colocar a cruz de madeira no local da execução do filho. Cosme marcou de ir com ela.

Saímos da casa dela e passamos em mais outras duas do bairro. Cosme é bastante conhecido por ali. Em ambas, Cosme parecia acompanhar um caso junto às famílias que 
envolvia processos judiciais. Nas conversas com os moradores, muitos condenavam a ação policial tanto quanto a do tráfico. Cosme falava muito contra esses últimos também, o que me fez questionar o quanto ele é um alvo no bairro. Durante as conversas, vi que a figura dele parece ser uma via mais eficaz para os moradores do que a associação de moradores locais, aos quais eles não acorriam. Ao longo do percurso, fomos observados e monitorados o tempo todo. 


\section{CAPÍTULO II - Sobre a produção do espaço urbano}

É importante ressaltar aqui a tentativa de um movimento de pensamento que parte de questões gerais, a começar pelo conceito de produção espaço, chegando até questões mais pontuais que dialogam de maneira mais clara com nosso fragmento espacial. Dada a natureza de nossa discussão sobre o espaço urbano, faz-se necessário debater o conceito de produção do espaço para assim discutir sua produção específica; na mesma medida, as aproximações acerca do termo urbano também interessam.

\section{1. - A produção do espaço na disputa}

Começamos por descartar qualquer concepção de espaço como uma forma pura, como receptáculo, como palco das ações humanas, ou ainda como categoria imanente de pensamento ou mesmo como pretensamente neutro. $\mathrm{O}$ espaço aqui tratado não é um dado a priori, nem da mente nem do mundo empírico. Tão pouco é visto aqui como uma mera expressão da estrutura social: embora em certo aspecto ocorra uma projeção das relações sociais sobre o terreno, o sentido de espaço nesse trabalho abrange uma definição mais complexa.

O espaço é compreendido nesse trabalho como condição necessária à vida, assim como é também uma dimensão da sociedade, sendo condição, meio e produto de relações sociais: elas se realizam enquanto relações espaciais (CARLOS, 2008). A relação homemnatureza é fundamento do processo constitutivo do espaço, processo que se realiza numa dialética entre objetividade (prática espacial) e subjetividade (consciência da prática). Todo corpo ocupa um lugar no espaço, se localiza, precisa da satisfação de um conjunto de necessidades, o que coloca uma objetividade nessa relação com o espaço, ao mesmo tempo a relação possui um caráter subjetivo formado pela consciência dessa prática espacial. É importante destacar que "espaço e tempo aparecem na análise geográfica em sua indissociabilidade, já que toda ação social se realiza num espaço determinado, num período de tempo preciso" (CARLOS, 2011:13). Portanto: 
O espaço como momento da produção social encontra seu fundamento na construção/constituição da sociedade ao longo do processo histórico como constitutivo da humanidade do homem. Assim, não haveria leis do espaço, nem a possibilidade de uma ontologia do mesmo, posto que sua produção situa-se na totalidade do processo histórico como processo civilizatório, como realidade prática. Dessa forma, significa dizer que não existe uma sociedade a-espacial, pois todas as relações sociais se cumprem como atividades determinadas por um espaço e um tempo - num espaço e num tempo definido pela ação. Desse modo, as relações sociais se materializam enquanto relações espaciais com significados diferenciados em função do tempo histórico. (CARLOS, 2011: 17-18)

Fruto de um processo histórico, o espaço social determina-se pela tendência que o torna um espaço homogêneo e abstrato. Podemos associar, por analogia, esse espaço destituído de qualidades com a tendência à abstração no capitalismo. Os escritos de Marx permitem perceber a identidade do capital como sua própria crise, sua auto destituição categorial. Sua qualidade consiste justamente em negar a qualidade (não qualitativo), em tomar a quantidade pela qualidade. Desfundamentar-se é seu fundamento. Isso explica a tendência crescente do capitalismo na ruptura com elementos advindos da história e um movimento em direção à abstração. A ideia que parece dominar o debate é de que "o espaço anulou o tempo", debatida por Harvey (2008). Embora não possa ser tomada como verdade absoluta, ela capta a percepção de que vivemos numa era fundamentalmente espacial, na qual a espacialidade é mais relevante, na qual as relações com a história são cada vez mais diluídas e a perda dos referenciais é o processo tendencial, o que não significou a anulação total da história ou o espaço como produto histórico, apenas aponta para a nova relevância da dinâmica espacial para nossa sociedade. Essa nova "preponderância do espaço" (ou “virada espacial”) pode ser vista, por exemplo, no aumento da importância do espaço para as constantes crises do sistema capitalista, seu incremento cada vez maior como força produtiva, como setor de negócios, como saída para a superacumulação do capital financeiro. Esse espaço abstrato é cada vez mais, tendencialmente, destituído de suas bases históricas. Para Ana Fani Carlos (2011: 31), a partir das ideias de H. Lefebvre:

A compreensão da história a partir do século XX exige a consideração da espacialidade num movimento da história que vai da dialética do tempo à 
do espaço. Isto é, refere-se ao desdobramento decorrente do desenvolvimento do processo de reprodução social, por meio do qual haveria na história um momento em que o processo de reprodução se realiza num outro patamar, que é aquele da produção/reprodução do espaço, momento em que implodem os referenciais vindos da história. Nesse sentido, o espaço permitiria a análise do mundo moderno na medida em que aparece como o mediato e o imediato, pertencendo a uma ordem próxima e distante: o lugar e o mundial.

O espaço é cada vez mais alvo de disputas, é o "objeto" em jogo, cada vez mais compondo os discursos de distintas classes sociais. Vemos que, no caso da remoção, o espaço onde ficava a comunidade era disputado entre moradores da comunidade e demais moradores do bairro, entre moradores removidos e prefeitura, nas disputas do tráfico de drogas no bairro novo, no discurso oficial que vende a remoção como necessária ao progresso e no contra discurso reivindicado pelo recém construído museu da ocupação. Em todas as instâncias e de todos os lados, o espaço está em disputa e o discurso sobre ele também é disputado. Lefebvre (2006) aponta que as contradições espaciais elevam as antigas contradições do capitalismo a um nível superior. Portanto, o espaço aparece em todas as suas tensões e disputas como algo em movimento. Destarte, vemos aqui espaço e sociedade como um par dialético no qual um se realiza no outro e pelo outro. A compreensão do mundo moderno passa, a nosso ver pela compreensão do espaço e de sua produção. Como argumenta Ana Fani Carlos (2011: 18):

Podemos inicialmente argumentar que a necessidade de compreensão do mundo moderno exige: a) compreender que a produção das coisas, mas também dos indivíduos, é determinada socialmente. Nesse sentido, o indivíduo e sua obra aparecem como produto da história; b) destacar que o processo de produção do espaço acentua a alienação do humano (tornado força produtiva e consumidor), na medida em que essa produção é percebida como exterioridade, vivida como estranhamento, posto que submetida às estratégias da reprodução do capital, bem como àquela da realização do poder político. Com isso, a perpétua reprodução das relações capitalistas aprofunda as contradições que estão na base do processo de 
produção do espaço e que despontam como conflitos, os quais aparecem como luta pelo espaço.

Dois pontos merecem ser comentados acerca da citação acima. O primeiro destaque é o item b, no qual o espaço vivido aparece como estranhamento e aponta para a exterioridade com a qual a cidade é vivida, na qual o ser humano não se reconhece como produtor daquele espaço. O estranhamento (CARLOS, 2001: 329) "liga-se à ideia de que a atividade produtiva tende a apagar, no capitalismo, seus traços, marcando o desencontro entre sujeito e obra" (grifo da autora). Mais adiante, quando discutirmos o uso e sua insurgência, veremos como o estranhamento contribui para impedir o uso. Por ora, nos limitamos a analisar que, quando a população se move, o novo lugar é percebido como estranhamento, como postiço, destituído da identidade da vida cotidiana. Tanto no espaço da ocupação quanto no bairro novo esse desenraizamento se impõe como realidade. Isso nos encaminha para pensar uma alienação do urbano, a produção de um espaço abstrato e amnésico. Desenraizados, eles precisam reconstruir uma relação com o lugar, o que nem sempre é uma tarefa fácil ou simples. No caso do bairro novo, isso se mostra pela sociabilidade cada vez mais para "dentro", com ruas esvaziadas e pouca convivência entre vizinhos, com o clima de relativo medo transmitido nas entrevistas, com os locais de encontro sendo esvaziados de sentido. No caso da ocupação, eles também tiveram dificuldades de estabelecer relações significativas com o espaço em seus entornos, relação que os caracterizava sempre como "os de fora", mesmo permanecendo mais de treze anos no mesmo lugar. Já na casa nova conquistada pelos ocupantes, esse sentimento de "ser de fora", de ser o outro, ainda permanece.

O segundo destaque é o item a, sobre a produção determinada socialmente. O espaço é um produto social (Lefebvre, 2006). Portanto, é um produto específico de uma produção específica e, ao produzir seu espaço, o ser humano produz também a si mesmo e à sua consciência. Esse produto único e peculiar, o espaço, assim como cada coisa produzida, contém e dissimula as relações que o produziram. Processo dialético e contraditório, a produção do espaço é o desenvolvimento de uma atividade social, com suas contradições advindas de seu conteúdo prático e social.

É importante ressaltar o duplo caráter da produção, como o faz Lefebvre (2006). A produção strictu sensu concerne apenas a produção de coisas, de mercadorias, na esfera da empresa. A produção lato sensu diz respeito ao processo mais geral de produção do humano 
e de sua consciência. Em dado momento, a esfera da produção extrapola o nível da empresa para invadir toda a sociedade. Ambos os processos, segundo Lefebvre estão relacionados e conectam-se à produção do espaço.

Objetivamos, com essa discussão, desviar o centro de nossa reflexão do espaço para a produção do espaço, pois, segundo Ana Fani Carlos (2011: 20):

A sociedade em seu processo constitutivo de humanização produz continuamente um espaço num movimento perpétuo, tornando-o imanente a sua própria existência. A noção de produção aponta a análise de um conteúdo que transcende as formas morfológicas ou a paisagem para enfocar o processo constitutivo dessa produção bem como os sujeitos dela, as mediações que tornam o processo real, tanto quanto a distribuição dos produtos desse processo.

A forma do espaço é um momento importante de ser captado, principalmente se pensarmos que a desigualdade se expressa materialmente na cidade. Ela é percebida, sentida e vivida por todos de diferentes formas. Contudo, não é suficiente o plano da morfologia se quisermos uma compreensão a partir do espaço dos fundamentos que reproduzem nossa sociedade. A noção de produção do espaço, portanto (CARLOS, 2011: 24):

Marca a passagem da compreensão do espaço produto da ação humana para a compreensão do movimento triádico, que entende o espaço pelo movimento ininterrupto que o define enquanto condição, meio e produto da reprodução social. O sentido do espaço está, portanto, associado à ação humana, à produção, ligando-se à noção de atividade e de trabalho, o que o situa no âmbito do processo de produção, do modo como o trabalho se divide a partir da hierarquização do grupo, de sua orientação, das relações de propriedade que comandam a divisão de seus frutos, a técnica e o conhecimento.

A escolha da perspectiva a partir da produção do espaço, destarte, se põe como fundamental, pois segundo Ana Fani Carlos (2011: 70):

A noção de produção, na perspectiva analisada por Marx e Lefebvre, permite reconstruir o movimento do conhecimento geográfico a partir da 
materialidade incontestável do espaço em direção aos conteúdos mais profundos da realidade social e em direção à descoberta dos sujeitos e suas obras. Nesse caminho a análise do espaço coloca-se como momento indispensável da compreensão do mundo contemporâneo.

$\mathrm{Na}$ perspectiva deste trabalho, a remoção-ocupação-periferização explicitam um movimento e um sentido da reprodução do espaço urbano, sendo, portanto, fundamentais para a reflexão aqui proposta.

Em suma, podemos retomar nossa discussão empreendida até esse ponto do trabalho levantando os seguintes pontos: nos termos da produção do espaço, percebemos que essa produção é anterior ao capitalismo e que toda sociedade produz o seu espaço, produzindo também a si mesma no processo; o espaço é uma dimensão da vida nas sociedades, portanto, o espaço como produção emerge da relação com a natureza transformando-a em algo próprio do humano (CARLOS, 2011:33). No capitalismo, o espaço é produzido como mercadoria, o que nos coloca diante da imposição de uma equivalência geral que o conduz à abstração; sob a forma mercadoria, o espaço é percebido como estranhamento, dada a dissociação, no capitalismo, entre produtor e sua obra. Na cidade capitalista ele é produzido coletivamente e apropriado privadamente, de forma contraditória (CARLOS, 2012).

\section{2. - O papel do espaço urbano na disputa}

A tendência revelada pelo urbano, no que Lefebvre (1999) coloca como período urbano, é de ruptura cada vez maior com fatores determinantes advindos da história, rompendo-se os referenciais históricos, enquanto a espacialidade ganha um papel central, ao mesmo tempo engendrada pelo modo de produção, mas interagindo em todos os níveis: organização do trabalho, relações de propriedade, força produtiva, instituições e ideologias, relações de produção. A perda dos referenciais evidencia a tendência à constituição de um espaço abstrato, fragmentado, homogêneo e hierárquico, em contradição com os espaços de uso, o espaço social. Enxergamos assim a principal contradição da modernidade, entre valor de uso e valor de troca, em seu conflito dialético.

O urbano engloba, portanto, a cidade, mas a transcende. Como momento histórico, produz um fenômeno qualitativamente novo: a problemática urbana. Conforme já 
assinalado, as mudanças ocorridas no capitalismo durante o século XX apontam uma série de questões novas: o movimento de reprodução como superação da produção stricto senso, saindo da estreita produção de mercadorias para expandir-se por toda a sociedade, instaurando-se o cotidiano. A centralidade assumida pelo cotidiano nesse novo contexto é crucial, como o é o papel do espaço tanto no aspecto de força produtiva quanto em suas outras faces: estratégia política, plano de realização e reprodução das relações sócioespaciais, lugar do uso e apropriação e também da coação e dominação, o alvo de disputa constante na cidade capitalista. É no urbano que enxergamos os conflitos no espaço envolvidos e elevados a um nível superior pelas contradições do espaço: a contradição entre público e privado, entre maior possibilidade de comunicação e empobrecimento das relações de sociabilidade, entre valor de uso e valor de troca. Mudou-se o foco: da produção à reprodução, do industrial ao urbano, da ampliação urbana à destruição criadora. $\mathrm{O}$ espaço urbano passa a ser, nesse contexto, o lócus principal da acumulação capitalista, o centro do desenvolvimento da modernidade e da cotidianidade no mundo moderno.

Compreendemos a importância crescente do espaço urbano para o momento atual do capitalismo. Entendemos que a reprodução do espaço tem sentido estratégico para o desenvolvimento capitalista, pois ele hoje se realiza produzindo espaço. $\mathrm{O}$ espaço ganha um novo papel na acumulação e nas relações de produção. Todavia, entre a reprodução do espaço urbano e sua finalidade para a acumulação existe a mediação do Estado, na forma como tratamos nessa pesquisa. Através da política pública da remoção, abriu-se espaço para o mercado imobiliário, ao mesmo tempo em que modificou profundamente os espaços-tempos cotidianos dos removidos: esses momentos agora nos revelam seu desenraizamento e seu estranhamento em relação à cidade, agora vivida ainda mais como privação. Se de alguma forma a remoção impõe o valor de troca, ela ao mesmo tempo impediu o uso. Pensando no caso do bairro novo, a distância espacial e o tempo de deslocamento inviabilizam uma vivência do restante da cidade, assim como irão de certa forma balizar suas formas de convivência e mesmo de resistência.

O processo de reprodução econômica passa agora pela produção de um novo espaço. Não restam dúvidas de que a acumulação passa pelo espaço, realizando-se através dele como condição e produto desse processo. Nesse sentido se explicam as atividades do turismo - com a correlata transformação da cultura em indústria cultural -, do narcotráfico, bem como o modo como o capital financeiro se associa ao setor imobiliário, 
atuando de forma cada vez mais clara na produção do espaço, em busca constante do lucro.

Segundo Ana Fani A. Carlos (2009), a reprodução do espaço urbano tornou-se uma condição para realização do capital financeiro. A produção da cidade objetiva a reprodução das relações sociais de produção como um momento da reprodução geral da sociedade. Com as atuais necessidades da acumulação capitalista em relação à realização de capital financeiro, aprofunda-se a hierarquização dos lugares, a divisão espacial do trabalho, o espaço posto como mercadoria. Essa urbanização produtora do espaço-mercadoria (sua produção é como raridade) o torna tanto investimento produtivo quanto mercadoria consumível, o que o faz participar de forma decisiva na acumulação capitalista.

Nesse contexto, o consumo no espaço passa ao consumo do espaço pela sociedade do consumo (não só no caso das cidades, mas podemos incluir também o turismo, presente na citação acima). O espaço do valor de uso assume um valor de troca, uma "equivalência geral". Aparece fragmentado, produzido como nova raridade e constituído como mercadoria, tendo seu uso social substituído pelo uso econômico. Sob o processo de produção capitalista todo produto é uma mercadoria, portanto nos defrontamos com uma cidade enquanto mercadoria e, embora radicalmente diferente de uma mesa ou celular, possui igualmente um valor de uso e um valor de troca. Esse processo de valorização da cidade que acompanha o processo de constituição do trabalho acumulado na cidade, tendo como fundamento a propriedade privada e a divisão da sociedade em classes, aparece e pode ser apreendido no processo de desfavelização aqui discutido.

Como um momento da reprodução geral da sociedade, a produção da cidade objetiva a reprodução das relações sociais de produção. Dadas às necessidades atuais da acumulação capitalista, em relação à realização de capital financeiro, aprofunda-se a divisão espacial do trabalho, a hierarquização dos lugares, o espaço como mercadoria.

A construção da sociedade move-se, assim, em direção à construção de uma morfologia que exclui e segrega, a uma estética que degenera a rua, onde o lúdico como modo de apropriação esvai-se num universo em que o lazer, cada vez mais submetido ao universo da mercadoria exacerba a segregação e impõe uma nova sociabilidade. (CARLOS, 2009, p.298). 
A cidade transformada em valor de troca, fundamentada na propriedade da terra, revela novas contradições: entre o valor de uso e o valor de troca; entre a produção social da cidade e sua apropriação privada; entre o espaço público e o espaço privado; entre um aumento da comunicação concomitante à diminuição das relações de sociabilidade. O plano da contradição é o do processo social de produção do espaço. Abarcam-se aqui três sentidos: o econômico, do espaço como mercadoria; o político, do espaço como estratégia, como repressão e dominação; e o social, do espaço da apropriação, do uso, que constitui a identidade, que qualifica a vida e aparece concretamente no plano da luta. É dentro desse enquadramento que nosso fragmento permite lançar luz a um processo maior e mais amplo e que, contudo, possui uma dimensão concreta na vida cotidiana das pessoas que o vivenciam: a cidade percebida como privação, segregada e fragmentada, cindida pela lógica da propriedade privada, o cotidiano vivido como adensamento da exploração e diminuição do tempo disponível para realização da vida. Fica muito evidente na fala nos removidos essa percepção de uma exploração em níveis mais intensos. Na fala dos moradores do bairro novo, nos limites da cidade, é muito comum aparecer o termo "isolados". Além do tempo maior gasto nos deslocamentos (subtraído do tempo de realização da vida), o valor monetário da passagem de ônibus é, para a grande maioria dos moradores, uma barreira praticamente intransponível.

Esse movimento geral revela uma problemática urbana que eleva o espaço urbano para o centro das preocupações no que tange a discussão sobre a reprodução das relações sociais. Nosso debate visa contribuir para lançar luz à problemática urbana ao discutir quais são as contradições por trás da desigualdade que aparece materialmente na cidade.

Em nossa perspectiva, o espaço serve tanto de instrumento ao pensamento quanto para a ação, ao mesmo tempo meio de produção e meio de controle. É alvo de disputas constantes na cidade capitalista. Além disso, é também foco de insurreições, levantes e resistências ao processo hegemônico. Portanto, o espaço entra de maneira fundamental tanto na esfera da normatização da vida quanto na esfera de resistência à norma. No contexto dessa pesquisa, ele é o instrumento repressivo e, ao mesmo tempo, instrumento de resistência. $\mathrm{O}$ espaço adquire, destarte, grande relevância como instrumento político, tanto por parte do Estado quanto dos movimentos sociais que o reivindicam. Embora a ideologia dominante reduza os problemas urbanos a questões locais e pontuais, trata-se do equacionamento de questões políticas, relativas à produção e a gestão do espaço. Um discurso sobre o espaço é hoje construído, fornecendo o diagnóstico de uma crise e propondo formas de superá-la. 


\section{3. - Habitação na cidade capitalista}

A primeira relação com espaço que temos é a de estar, portanto do ato de morar. $\mathrm{Na}$ cidade capitalista esse ato coloca problemas, pois a reprodução da sociedade repõe o tempo toda uma série de desigualdades do processo de produção: divisão de classes, concentração da propriedade privada da riqueza, a relação entre riqueza e poder, etc.

A habitação aparece como mercadoria necessária à reprodução da força de trabalho, necessária a vida, mas não de acesso a todos. Arlete Rodrigues (2003) destaca o papel singular assumido pela habitação, dada sua indivisibilidade, dentre uma série de características únicas da mercadoria moradia: sempre se pode pedir um prato de comida ou uma roupa, mas não se vê alguém pedindo para "morar um pouquinho" na casa alheia. Tratase de uma mercadoria única e essencial para a reprodução da vida.

Contraditoriamente, o sentido da urbanização revela-se como negatividade da habitação: o espaço cada vez mais fluido da circulação, necessário ao movimento de reprodução do capital, de uso "produtivo". Devido às restrições de acesso à mercadoria habitação, proliferam pela cidade as soluções habitacionais da população de baixa renda: comunidades, cortiços, loteamentos clandestinos e ocupações. Essas vias alternativas de resolver o problema de moradia buscam uma solução barata e viável para algo extremamente caro na cidade capitalista: a casa. Porém, uma vez que a casa tornou-se mercadoria, seu acesso só pode se dar por meio do mercado imobiliário. Para Ana Fani Carlos (2011: 65):

O espaço é vivido de forma distinta quando a habitação torna-se uma mercadoria, quando o ato de habitar passa a ser destituído de sentido, decorrente do fato de que os homens se tornam instrumentos no processo de reprodução espacial, e suas casas se reduzem à mercadoria, passíveis de ser trocadas ou derrubadas (em função das necessidades do crescimento econômico). Nessa lógica, a atividade humana do habitar, da reunião, do encontro, do reconhecimento com os outros e com os lugares da vida ganha uma finalidade utilitária. (...) Quanto mais o espaço é submetido a um processo de funcionalização, mais é passível de ser manipulado, limitandose, com isso, as possibilidades de apropriação. Nesse processo, o indivíduo de reduz à condição de usuário, enquanto o ato de habitar, como momento 
de apropriação criativa, se reduz ao de morar, ou seja, à simples necessidade de abrigo.

Para a autora, habitar é um ato real e concreto. É ele que constrói memórias e identidades a partir do espaço, que traz as dimensões do uso e da vida. É nesse ato que encontramos o corpo, a presença e o vivido.

Henri Lefebvre (2001) trabalha o conceito de habitat como o habitar elevado à sua forma pura e abstrata pela burocracia estatal: trata-se da habitação marcada por uma característica funcional, objetiva e homogênea. O objetivo não poderia ser outro senão o de assegurar as condições de um nível mínimo de estrutura para a reprodução da força de trabalho, tão somente. Na visão de Damiani (1994: 105):

Essas soluções no plano urbanístico, na realidade são políticas importantes e impositivas de um modo de vida. Uma concepção segregada e segmentada, estratificada de política urbana é uma concepção possível a partir de bases modernas.

A autora coloca em vista o urbano sendo reduzido à lógica da sociedade industrial, de homens que são administrados em seus tempos e necessidades, e destas as mínimas. Lefebvre argumenta que "o habitat foi instaurado pelo alto: aplicação de um espaço global homogêneo e quantitativo obrigando o 'vivido' a encerrar-se em caixas, gaiolas, ou máquinas de morar" (1999:79, apud SAMPAIO, 2015b: 74).

Na lógica de um espaço como força produtiva, como condição e meio da acumulação, da habitação como mercadoria, e da cidade como lócus principal da ação do capital financeiro, as políticas de habitação brasileira materializam-se como demanda para mobilização de capitais excedentes e ociosos, na forma de crédito. Para Harvey (2011) a produção do espaço urbano tornou-se a melhor maneira de absorver excesso de capital.

O conjunto habitacional construído pela prefeitura para se tornar o bairro novo Jardim São José II, para onde foram os removidos, seguiu a lógica da construção em série de casas padronizadas, feitas ao menor custo possível, pensadas para atender às necessidades mínimas mais essenciais das famílias que as receberiam. $\mathrm{O}$ espaço interno é pequeno e não foi pensada nenhuma alternativa para as famílias que cresciam.

Essa construção foi um empreendimento financeiro para as construtoras envolvidas e absorveu grande quantidade de capitais. Porém, sua importância como negócio vai além 
do valor gasto nas casas do bairro. Além disso, as vias de acesso construídas para o bairro novo valorizaram os entornos, permitindo a construção de bairros novos (não pela prefeitura, mas pelo setor imobiliário) e a valorização de bairros periféricos de feições quase "rurais", como o bairro Capão Grosso, local onde coincidentemente mora minha mãe (alguns desses moradores chamavam seus terrenos nesses bairros de "chácaras"). Esses bairros agora estão sendo alvo de várias obras de infraestruturas: ruas asfaltadas, ligações entre os bairros periféricos e com vias de maior circulação, como a rodovia Presidente Dutra. Isso permitiu o desenvolvimento do mercado imobiliário da zona leste da cidade, o que aumentou o potencial da região de absorver excedentes de capital por meio do setor imobiliário.

Para analisar essa construção e seu papel para o setor imobiliário, pensamos o processo a partir da ideia de espoliação urbana (Kowarick, 1979, 2000) sobre os moradores das antigas comunidades, cujo objetivo, no limite último, é a ampliação do capital no setor imobiliário, embora desdobramentos menores estejam associados e sejam mais a frente discutidos, como, por exemplo, o papel ideológico da remoção. Trata-se de uma desfavelização, uma estratégia de segregação de uma parte pobre da população, em benefício não apenas da valorização dos terrenos entorno das antigas áreas de comunidades da zona leste, mas também como possibilidade de negócios no local novo para onde iriam. Os moradores removidos, evidentemente, têm sua condição como fruto dessa lógica. Além dos custos maiores, e não apenas financeiros, mas também em quantidade de tempo e esforço gastos durante os deslocamentos, a desigualdade de acesso e oportunidades a que são submetidos não pode ser aferida. Absorver a desvantagem de ser o primeiro grupo a "desbravar novas áreas da cidade" também permite a constituição de novos eixos a serem explorados pelo setor imobiliário.

Vemos, portanto, como a construção do bairro novo permitiu a integração, de maneira periférica, desses espaços ao movimento de reprodução do capital de forma mais contundente, em um processo que vai além do bairro novo em si.

\section{4. - As soluções habitacionais na cidade capitalista}

As soluções habitacionais conhecidas como favelas e cortiços aparecem na cidade capitalista como uma primeira resistência ao sentido de negação do acesso à habitação. $\mathrm{Na}$ 
cidade capitalista a parcela mais pobre da população não possui condições de acessar a moradia pela via do mercado imobiliário, portanto precisa buscar soluções práticas visto que morar é um ato de primeira necessidade na cidade.

Desde a constituição do que Lefebvre chama de urbano, principalmente na virada do século XIX para o século XX, já se evidencia a produção de estratégias de sobrevivência e resistência à face mais excludente (em certo sentido) do processo de urbanização. Porém, não há nesse trabalho a noção de exclusão, sendo preferido antes o conceito de inclusão precária de que fala José de Souza Martins (1997; 2008). Entendemos que não há no capitalismo a ideia de "excluídos sociais", pelo contrário, fazem parte de uma lógica de desenvolvimento desigual da urbanização capitalista posta por e pela simultaneidade da crise capitalista.

Nossa hipótese para entendimento dessas soluções habitacionais desenvolve-se no seguinte sentido: elas surgem inicialmente como resistência ao sentido de negação da habitação que a cidade oferece aos seus moradores mais pobres. No contexto de industrialização das cidades brasileiras, ela aparece como uma forma de rebaixar salários e baratear a mão de obra, uma vez que permite reduzir custos com moradia. Destarte, sua existência passa a ser, de certa forma, "tolerada" em alguma medida, em especial as que não estão em áreas muito centrais. Dada a passagem do capitalismo industrial para o capitalismo financeiro, na qual a atividade industrial reduz sua importância em relação ao setor terciário, o espaço passa a ser o foco do processo de acumulação e, nesse novo contexto, todos os "empecilhos" ao processo de valorização do espaço precisam ser removidos. Ao serem realocados em áreas periféricas da cidade, permitem a integração de novos espaços ao circuito do setor imobiliário, uma vez que os serviços públicos que chegarão até esses locais e valorizarão terrenos, permitindo novos negócios imobiliários.

O crescimento das soluções habitacionais é vinculado, neste trabalho, ao movimento de expansão da industrialização nas cidades brasileiras. Ermínia Maricato (2015) realiza a mesma relação entre a expansão da metrópole industrial e o aumento do número de comunidades. Para Fabiana Valdoski Ribeiro (2014: 306-307), o contexto de proliferação acelerada de comunidades está associado à intensificação da urbanização durante a industrialização tardia:

$\mathrm{Na}$ intensificação da urbanização, a partir dos anos 1960 pela industrialização tardia, há a proliferação de morfologias diferenciadas, 
com destaque para aquelas mais precárias, como as favelas. Estas são fruto da exploração do trabalhador pautada na extração de mais-valia absoluta, com baixos salários e grande jornada de trabalho, além de precários direitos trabalhistas.

Para a autora, a morfologia da favela é a forma "mais representativa do processo de expropriação e de espoliação do trabalhador urbano" (p. 310).

Esse contexto de rápida e intensa expansão industrial foi vivido na cidade de São José dos Campos. A cidade localiza-se no Vale do Paraíba, uma das cidades cortadas pela rodovia Presidente Dutra. Como outras cidades paulistas, São José dos Campos passou por um acelerado processo de industrialização a partir principalmente dos anos 1950. Através do que se chamou "guerra fiscal" entre os municípios, a cidade ofereceu isenções e terrenos gratuitos para instalação de grandes indústrias que foram extremamente influentes nos rumos da cidade. No contexto da reestruturação produtiva do estado de São Paulo nos anos 1970, todo o macroeixo Rio - São Paulo viu-se alvo das políticas de desenvolvimento do período, como o PND (Plano Nacional de Desenvolvimento) a nível nacional, e o CODIVAP (Consórcio de Desenvolvimento Integrado do Vale do Paraíba e Litoral Norte) a nível regional. Portanto, o contexto do planejamento estatal para a região já se dá de maneira presente desde o primeiro relatório de diagnósticos publicado em 1971. São José dos Campos destacou-se no cenário estadual por seu grande crescimento industrial, com empresas como General Motors e Embraer, além de sede de institutos como INPE (Instituto Nacional de Pesquisas Espaciais), CTA (Centro Técnico Aeroespacial) e a faculdade de engenharia ITA (Instituto Técnico Aeroespacial).

Essa expansão industrial teve, evidentemente, rebatimentos na dinâmica urbana. O grande crescimento econômico e industrial da cidade foi seguido por um processo intenso e acelerado de aumento populacional. A urbanização pautou-se em um modelo de organização espacial voltado para a industrialização, o que direcionou os recursos, investimentos públicos, todo o sentido de atuação no espaço urbano por parte do Estado, unicamente para esse fim.

Podemos, através dessas ideias, vincular a proliferação de soluções habitacionais ao longo do século XX, em especial na segunda metade, ao avanço da industrialização e sua necessidade crescente de aumento das taxas de exploração para extração de mais-valia. É importante destacar que vemos na expansão das taxas de extração de mais-valia um dos 
aspectos da reprodução crítica do capitalismo. Sua grande expansão em termos quantitativos e absolutos visa repor sua perda constante em termos relativos, visto que, conforme analisou Marx através da queda tendencial da taxa de lucro, o capital perde cada dia mais sua capacidade de explorar o trabalho.

As comunidades assumem um papel na cidade industrial, do ponto de vista do empresariado, por sua capacidade de rebaixar os salários, ou seja, elas permitem que os custos com moradia da parte do trabalhador fiquem mais baixos, o que, na prática, se traduz na possibilidade de o empregador pagar salários menores. Em alguma medida, a comunidade é tolerada pela gestão municipal pela sua "funcionalidade", desempenhada do ponto de vista de reserva de mão de obra barata e acessível nas áreas relativamente próximas ao centro.

Com a transição do capitalismo industrial para o capitalismo financeiro e a mudança qualitativa dos conteúdos do processo de urbanização, a função de reserva de mão de obra da comunidade perde sua importância, enquanto ela aparece simultaneamente como um empecilho cada vez maior ao processo de valorização do espaço. Dada a impossibilidade cada vez maior de investimentos produtivos, da extração cada vez menor de mais-valia, de uma crise generalizada na produção do valor que acaba por desvalorizá-lo constantemente, o espaço surge no bojo dessa aparente expansão quantitativa das linhas de investimentos, que na verdade são a própria expressão da crise: o capital se expande quantitativamente por já não conseguir se remunerar nas linhas tradicionais, por sua perda constante da capacidade de explorar trabalho. A expansão, em termos quantitativos, expressa sua crise por não conseguir repor seus pressupostos, portanto é um acirramento da exploração devido a sua perda de capacidade crescente de explorar trabalho, na qual o espaço ganha um novo papel na acumulação e nas relações de produção.

$\mathrm{Na}$ metrópole industrial, a comunidade pode estar relativamente perto do centro. $\mathrm{Na}$ metrópole financeira ela já não pode estar ali, pois o foco é valorizar o espaço em si, o espaço é o objeto prioritário e ela não pode mais ser tolerada. Isso ressignifica a comunidade, pois ela está no meio do caminho do fenômeno imposto pelo processo de valorização. A urbanização contraditória, ao se desenvolver, valoriza o espaço, e essa valorização se realiza com a expulsão de uma parcela da população que não condiz com o novo padrão local. Esse processo de valorização se dá em detrimento da vida.

O sentido de comunidade nessa nova perspectiva muda completamente. O sentido tradicional de favela resume-se ao lugar da ausência, são os chamados Setores Especiais de Aglomeração Subnormal: 
Para o IBGE, são Setores Especiais de Aglomeração Subnormal os conjuntos constituídos por um mínimo de 51 domicílios, ocupando ou tendo ocupado até período recente terreno de propriedade alheia (pública ou particular), dispostos, em geral, de forma desordenada e densa, e carentes, em sua maioria, de serviços públicos essenciais. (MARQUES e SARAIVA, 2011).

Essa ideia, para fins de coleta de dados, é insuficiente e desatualizada, dada a realidade das comunidades hoje. Portanto, rejeitamos uma definição que se pauta exclusivamente pelas ausências: de padrões urbanísticos desejáveis, de relações de propriedade legalmente reconhecidas, de serviços e equipamentos públicos. Pois define-se, dessa forma, pelo que não é ao invés de pelo que possui de fato. As casas no Morro do Regaço, por exemplo, eram de alvenaria, os serviços já chegavam até lá, ao menos em parte, e boa parte das ruas possuía placas e numeração.

$\mathrm{Na}$ nossa perspectiva, a comunidade aparece como solução habitacional da população mais pobre ao lado mais violento da urbanização, que lhes nega o acesso à essa mercadoria fundamental à vida que é a habitação. São espaços que, de alguma forma, resistem à face mais cruel da constituição do urbano. Embora vista como problema do ponto de vista do poder público, é uma solução do ponto de vista dos moradores, muitas vezes a única possível. Para os que vivem sob a situação de urgência e necessidade, a comunidade aparece como condição de existência.

É evidente que as comunidades não podem ser vistas como áreas específicas a parte do resto da cidade, ou mesmo como uma cidade dentro da outra, pois participam do processo geral de produção da cidade. As favelas integram processos exploratórios de espoliação urbana dentro de uma lógica mais geral indissociável da realidade local dos moradores. Além disso, inserem-se na cidade por meio de empregos ocupados tradicionalmente por seus habitantes, como a construção civil e o trabalho doméstico, conectando-se assim a outros espaços da cidade.

Paralelo à constituição das comunidades, existe a construção de um discurso que se constrói em torno da visão homogeneizante do "favelado". Isso de certa forma modela a maneira como esses espaços são concebidos pelo restante da cidade. O papel da mídia policial, do discurso sobre a violência, da criminalização da pobreza, constrói uma favela no 
imaginário social: um território de crime e imoralidade, dominado por drogas, violência e desorganização familiar. Os moradores desses espaços passam a ser alvo dos mais diversos preconceitos, não sendo raros os moradores que escondem sua condição. Favelado tornouse termo pejorativo, sinônimo de pobreza, associando-se todos a um comportamento potencialmente violento ou desonesto.

Além do preconceito, os moradores de favelas ainda convivem com uma intensa vulnerabilidade civil: precariedade das habitações, os riscos ambientais, a instabilidade e o preconceito, a ameaça à integridade física (Kowarick, 2009). Todos esses pontos reforçam a ideia do urbano vivido por eles como privação. Nesse sentido, a remoção não criou as condições precárias nas quais eles hoje estão inseridos, apenas as transformou qualitativamente.

\section{5. - O papel do Estado na cidade capitalista}

O espaço é dominado pelo Estado como fonte de poder e como base da reprodução do capital. Nesse último sentido, o espaço aparece como a fonte de demanda para o capital financeiro crescentemente em crise, que cada vez mais ocioso desvaloriza-se. Esse capital encontra na construção civil e no mercado imobiliário uma via de circulação extremamente favorável, em grande parte graças à ação estatal, pois o Estado viabiliza muitos negócios através, por exemplo, das operações urbanas. É, portanto, compreensível a centralidade que o espaço urbano assume nessa perspectiva. Sua re-produção, e sua obsolescência programada, colocam-se no âmbito das "destruições criadoras", no sentido contraditório do espaço produzido ser ele mesmo barreira para acumulação. Portanto:

\footnotetext{
“a mobilização do espaço torna-se frenética e leva à autodestruição de espaços produzidos. (...) Aqui, ainda, a estratégia, ou melhor, as estratégias da classe dominante se revelam perigosas, cheias de riscos, destruindo o possível e o futuro, submetendo-os a interesses momentâneos, a curto prazo." (Lefebvre, 2008, p. 120).
}

Conforme vimos anteriormente, a ideia de produção em seu sentido amplo refere-se 
não somente à produção de coisas e objetos no espaço, mas abarca também a produção e reprodução de relações sociais. Para Ana Fani Carlos (2011: 29):

A produção é também reprodução de relações sociais; o que acrescenta algo novo à produção. Existe, portanto, a produção-reprodução do espaço social como necessidade do modo de produção enquanto manutenção das relações de dominação. Com base nesse processo, não podemos omitir nem o lado estratégico e político da reprodução, nem a importância que o Estado assume para manutenção geral das relações sociais.

Mais adiante (2011:31), a autora destaca que, "a reprodução das relações sociais nesse momento envolve, portanto, a ação estratégica do Estado que produz um espaço apropriado a partir de sua utilização no plano do vivido". Ainda segundo Ana Fani Carlos (2006: 77):

\footnotetext{
"as políticas urbanas, em nome do progresso, escondem (nem sempre com sucesso) os interesses imobiliários que no seu desenvolvimento deslocam favelas, expulsam os moradores das áreas que se valorizam com a intervenção do Estado, que deixam de ser compatíveis com as mudanças (leia-se, expulsão da população com poder aquisitivo inferior àquele que a 'nova área' deverá atrair)".
}

As transformações no entorno da área onde ficava a comunidade do Morro do Regaço, alvo de especulação e negócios imobiliários, parecem apontar para uma finalidade financeira que foi em maior ou menor medida adotada e posta à prática pelo poder público. Porém, é preciso tomar cuidado com a visão do Estado apenas como instrumento de dominação de uma classe. Conforme argumenta Renata Sampaio (2015b), esse pensamento carrega em si o princípio da neutralidade estatal, segundo o qual o problema do Estado está no fato de ele ter sido "capturado por uma classe social". Isso levaria, por conseguinte, ao raciocínio de que, em boas mãos, ele pudesse atuar com outros princípios. Isso, segundo ela, nos afasta de uma crítica estrutural e radical do Estado.

Em nossa pesquisa, observamos que o que inicialmente aparece como uma intencionalidade executada racionalmente na verdade desvela-se como lógica fundante do Estado burguês, sem a qual ele não se repõe enquanto Estado: o espaço enquanto via 
principal de reprodução do capital, e também como vital à definição essencial e clássica de Estado (pela via do Território como espaço dominado por um Estado), é necessariamente o alvo principal da atuação governamental. O Estado se faz enquanto tal ao dominar um espaço, nessa definição. Além disso, ele possui a capacidade única de, por exemplo, desapropriar uma comunidade inteira para viabilizar certas operações essenciais para o setor imobiliário. A lógica dessa atuação é definitivamente de natureza autoritária e burguesa de um Estado capitalista. Não se trata, portanto, de personificar na gestão municipal uma vilania ou intencionalidade, pois embora reconheça-se aqui o papel decisivo da política em muitas situações, e mesmo a existência de diversas lógicas contraditórias internas ao aparelho estatal, não se pode fugir do enquadramento geral posto pela lógica do capital na sociedade e por um Estado capitalista. Sem seguir esse panorama ele não se repõe enquanto Estado. A regra geral, portanto, é que não se pode esperar da via estatal, no contexto atual e com poucas exceções pontuais, alguma intervenção que não se vincule a essa lógica geral, independentemente da gestão. Não se trata de uma defesa explícita do Estado como um mero cumpridor de interesses da burguesia de forma automática e mecânica; contudo, ainda que uma ação estatal apareça como contrária a lógica do capital e seja fruto de uma decisão política, ela ainda assim será, sempre, uma ação em tentativa de perpetuação do poder com o objetivo único de garantir a reprodução social nos moldes burgueses capitalistas e estará enquadrada em menor ou maior grau na lógica geral do capital, ou seja, crise como sua forma identitária, sua objetividade, na qual o Estado aparece como administrador da crise e como mantenedor das relações sociais de produção.

O Estado intervém no urbano, segundo Ana Fani Carlos (2011: 76), da seguinte forma:

Intervêm no processo de produção da cidade criando/reforçando centralidades como forma de dominação, reforçando a hierarquia dos lugares em função de sua importância estratégica para a reprodução, criando novas centralidades como produto do desenvolvimento do capitalismo em suas novas exigências, impondo sua presença em todos os lugares, agora sob controle e vigilância (seja direta ou indireta) através da mediação da norma. Desse modo, o Estado desenvolve estratégias que orientam e asseguram a reprodução das relações no espaço inteiro (elemento que se encontra na base da construção de sua racionalidade) produzindo-o enquanto instrumento político intencionalmente organizado 
e manipulado. O espaço é, portanto, um meio e um poder nas mãos de uma classe dominante, que diz representar a sociedade, embora não abdique de objetivos próprios de dominação e que usa as políticas públicas para direcionar e regularizar fluxos, centralizando, valorizando e desvalorizando os lugares através de intervenções como "ato de planejar". Nessa condição o espaço se pretende homogêneo (pela dominação) e hierarquizado (pela divisão espacial do trabalho). Como produto, evidencia-se o espaço da norma e da vigilância como forma de construção de um espaço estratégico.

A partir da citação acima, podemos antever as várias formas pelas quais o Estado intenta sua intervenção no espaço urbano. Contudo, seu poder de homogeneizar a tudo não é total e absoluto, pois uma parte desse processo se constitui enquanto diferença, ainda que de forma residual, conforme será discutido mais adiante. A capacidade de dominação pela vigilância também será relativizada adiante através do conceito de TAZ. Por ora, basta saber que o Estado almeja ser onipresente e atua por meio do espaço para seguir essa linha tendencial, embora ela nunca se complete.

De acordo com Renata Sampaio (2015b: 70), o papel do Estado é bastante amplo:

O que é interessante derivar é o fato de que o papel do Estado não se resume a assegurar o crescimento e o processo de acumulação do capital, estritamente; ainda que essa seja a consequência lógica de sua atuação. A extensão e a generalização da forma mercadoria, bem como a universalização das relações de troca é o que permite a formação de uma base social tanto para o capital quanto para o Estado; é o que possibilita e justifica, simultaneamente, o processo de acumulação do capital e exercício do poder político do Estado - que Lefebvre chegou a considerar como um processo de acumulação política. Assim, "a atividade estatal deve garantir e realizar as equivalências, aproximando-as da identificação pura e simples; ela as realiza pelo alto e como centro, penetrando todas as esferas das relações sociais, até as mais banais e cotidianas". (grifo da autora)

A generalização da equivalência, para ela, não se realiza apenas pelo mercado, mas 
pelo Estado e essencialmente por ele. Esse ponto será importante adiante, quando discutirmos a ideia de inerência da violência ao processo de urbanização. Nesse momento, nos basta pensar em outros aspectos possíveis da ação do Estado na remoção que não apenas a força policial e as máquinas de demolição.

Podemos observar, como exemplo da atuação do Estado, como o discurso da parte estatal parece vender a ideia de que as intervenções urbanas pareçam uma necessidade social, e as desapropriações são vistas como um pequeno "empecilho", um "mal necessário" para que venha o tão necessário progresso, que faz "crescer o bolo" para que depois se possa dividi-lo.

O papel do Estado no processo foi importante não só na remoção pela força. Um discurso é construído com base na ideia de progresso, vendem a cidade como a imagem da eficiência e modernização. Não há espaço para pobreza no cenário ideológico joseense, pois contraria a perspectiva de um prefeito como gerente da cidade do futuro, como administrador eficaz, tais quais as campanhas políticas do PSDB veiculavam já na primeira eleição de Emanuel Fernandes. Assistiu-se em São José dos Campos o que se viu em muitas cidades do Brasil e do mundo: a emergência de um poder público cada vez mais empreendedor vendido com a imagem de "gestão" eficiente, supostamente distanciada das impurezas do mundo da política. Essa transformação da visão do Estado pouco tem a ver com alguma concepção de gestão municipal dos prefeitos, mas apresenta-se como forma necessária de ser do estado diante das atuais contradições do capital entre o econômico e o político, que, embora apareçam como vontade de classe, está enquadrada no panorama geral em que o Estado não se reproduz enquanto tal se não for empreendedor.

Essa mudança de foco justificou a violência da parte do Estado: forçar a adesão, forçar a remoção, forçar um novo cotidiano. Foram submetidos a todo tipo de fraude e ameaça: os empregos prometidos em troca de adesão não aconteceram, as novas casas foram entregues ainda inconclusas, chegou-se até a um ultimato por parte da prefeitura para quem não aderisse. Os custos sociais das medidas de planejamento urbano executadas são evidenciados não só no histórico de violência e coerção na remoção, mas também na análise da mudança no cotidiano dos removidos, agora ainda mais onerados por processos espoliativos. Além deles, também os moradores da ocupação sofreram até com a perda de todos os móveis pela recusa em aderir ao programa, pois, segundo as entrevistas, apenas retirava-se algum pertence do galpão da prefeitura mediante adesão. 


\section{CAPÍTULO III - A violência da urbanização}

O objetivo aqui é discutir a face violenta da urbanização. Os movimentos de resistência à urbanização contrapõem-se a um aspecto do processo, que a eles se manifesta em sua face mais violenta. Intentamos entender, através do fragmento espacial aqui analisado, que o processo que constitui a urbanização realiza-se de forma violenta. No caso específico dessa pesquisa, tentamos entender os conteúdos dessa violência da urbanização através daqueles que a ela resistem. A manifestação específica dessa violência, em nosso estudo, foi principalmente por meio da segregação socioespacial. Porém, vislumbramos ainda outras interpretações possíveis para os conteúdos violentos da urbanização que se desdobram a partir de nossas pesquisas de campo.

A primeira interpretação possível da face violenta do processo de urbanização pode ser vista como a cidade vivida como privação. Essa privação é manifestada, por exemplo, na negação do acesso à habitação e nas decorrentes condições precárias de moradia, seja na comunidade antes da remoção, seja no bairro novo após a remoção, seja na habitação improvisada da ocupação. Em todos esses casos, um determinado grau de resistência foi necessário como condição para suportar o modo violento como o urbano se impõe, uma vez que estão privados do acesso aos produtos considerados benéficos da urbanização, já que esse acesso é condicionado pela propriedade privada de dinheiro e da terra. A privação também se manifesta na impossibilidade dos moradores do bairro novo de viver plenamente a cidade, visto que estão na condição definida por eles como "isolados". Lá, não possuem acesso aos mesmos serviços que o restante da população da cidade.

Uma segunda forma de enxergar a urbanização como violência, essa relativamente mais clara, é o processo de remoção em si, realizado à força de forma truculenta pelas forças policiais. É pela força que se impõe a condição segregada à essa população (mesmo a parte dos que aderiram voluntariamente ao programa relatam como essas adesões foram à base coações de toda natureza). O tratamento recebido pelos moradores das forças policiais é sempre diferente do que recebem os moradores das áreas mais valorizadas da cidade. Relaciona-se a isso a terceira forma de vermos a urbanização em sua face violenta, que é o imaginário social que coloca os moradores da comunidade (antes da remoção), os moradores do novo bairro na periferia (após a remoção) e os moradores da ocupação (mesmo após mudarem para as casas conquistadas) na condição de subcidadãos. O preconceito presente 
com os moradores desses espaços manifesta-se como uma forma de violência. Jovens do novo bairro relataram que precisam esconder seu real endereço quando fazem currículos, pois o nome do bairro Jardim São José II pode literalmente impedir a contratação. Isso os força a procurar comprovantes de endereço de parentes e conhecidos fora do bairro, na tentativa de encontrar emprego. As abordagens policiais também são relatadas como mais frequentes e mais violentas no bairro novo, visto pelas forças de segurança como a "Cidade de Deus", lugar em que toda truculência pode e deve ser aplicada. Lembremos aqui o caso da mãe que, de acordo com o relato dela, teve o filho assassinado em uma execução sumária pelas forças policiais.

\section{1. - Segregação e violência na cidade capitalista}

O que talvez seja a principal forma de violência da urbanização é o uso econômico do espaço suplantando seu uso social. Anunciamos anteriormente os novos papéis assumidos pelo espaço na cidade capitalista. Destacamos a forma como, na cidade capitalista, o espaço homogeneíza-se, como espaço abstrato, tornando-se mercadoria. O Estado e o setor imobiliário realizam um papel fundamental nessa disputa por espaço na cidade, dando ao espaço um novo e decisivo aspecto nesse contexto, agora cada vez mais integrado aos circuitos de capital. Para Fabiana Valdoski Ribeiro (2014: 304):

Essa nova dimensão do papel do espaço no nível econômico e político implicará inúmeras consequências no âmbito social. Por um lado, a integração contínua do espaço aos circuitos capitalistas vai permitir a reprodução do próprio sistema através de reiteradas expulsões de moradores de morfologias antigas e que não correspondem aos novos padrões de rentabilidade; Por outro, desintegra as sociabilidades produzidas no cotidiano dos moradores das cidades por meio da generalização da segregação socioespacial. Para levar a cabo a integração espacial com a finalidade de homogeneização do espaço, a prática urbana estatal articulada ao privado produz variadas políticas do espaço. Essas últimas representam um conjunto de ações que transformam profundamente a morfologia espacial, redefinindo usos, funções e 
estruturas urbanas. Elas carregam em seu bojo a desintegração dos espaços-tempos pretéritos daqueles que viviam no lugar. (grifo nosso)

Para Fabiana Valdoski Ribeiro, quando o novo papel é assumido pelo espaço na contemporaneidade, o próprio sentido de segregação socioespacial adquire novas qualidades e dimensões (2014: 305):

Vivemos uma crise urbana pautada na generalização da segregação socioespacial, acarretando a permanente emergência de resistências para sobreviver na cidade capitalista. (...) Com a renovada função do espaço na economia capitalista, a orientação de sua produção modifica-se e o próprio sentido de segregação adquire outras qualidades e dimensões, transformando-a em um processo fundamental e necessário na reprodução capitalista do espaço urbano e, desse modo, revelando um dos aspectos da crise urbana.

Pelo excerto acima, podemos derivar dois pensamentos que iluminam o caminho percorrido por esse trabalho: o primeiro, de que é justamente esse conjunto de outras dimensões e qualidades do processo de segregação que essa pesquisa visa iluminar, na medida em que o estudo dos movimentos de resistência à urbanização e seus conteúdos permite vislumbrar, ao mesmo tempo, um sentido mais profundo da segregação na cidade capitalista como um dos fundamentos da violência da urbanização, apoiado na concentração de riqueza através da propriedade privada da terra e do dinheiro. O segundo, é que esse estudo revela um dos aspectos da crise urbana, portanto aponta para uma realidade maior do que a de nosso estudo específico de caso. Destarte, os conteúdos da segregação socioespacial iluminam processos maiores a partir da compreensão de nosso fragmento.

A segregação pode ser inicialmente pensada como uma desigualdade de acesso. No contexto urbano, isso significa uma desigualdade de acesso aos produtos benéficos da urbanização. Essa desigualdade de acesso aos benefícios da urbanização é um produto social, fruto da disputa política pelo direito à cidade e, no limite, um dos sentidos possíveis da palavra segregação. Segundo Marques (2005), a segregação em termos socioespaciais envolve ao menos três processos distintos: o primeiro seria total isolamento, podendo estar associado à ideia de guetos, com barreiras físicas e restrição de circulação; o segundo seria 
a desigualdade de acesso, tanto de políticas publicas quanto de condições de vida em geral; por fim, o terceiro significaria separação, uma homogeneidade interna e heterogeneidade externa na distribuição dos grupos no espaço. Para o autor, os dois últimos casos, desigualdade de acesso e separação, são indissolúveis, pois se constroem e reconstroem mutuamente e é necessário levar em conta essa dinâmica conjunta. Vemos que mesmo nas definições de fora da Geografia (Eduardo Marques é cientista político), o espaço aparece como fundamento principal do processo de segregação.

No plano do cotidiano, essa diferenciação de acesso fica latente. De acordo com Ana Fani Carlos (2015a: 60):

No plano do cotidiano, a segregação como forma de desigualdade demonstra a diferenciação dos acessos ao urbano e à vida em sociedade. A metrópole se reproduz como exterioridade (estranhamento e reconhecimento que permeiam a prática socioespacial), onde a privação dos direitos funda e orienta as relações sociais atualizando a alienação do mundo moderno, no qual a consciência espacial é o outro desta reprodução. A segregação surge e expressa-se na vida cotidiana diante do extenso processo de privação que acompanha a realização da vida. Aparece e constitui-se nos interstícios, ganha sentido na reunião das pessoas em torno da insatisfação das necessidades nunca atendidas; das injustiças na distribuição da riqueza social; da intolerância entre membros de classes sociais diferenciadas; das políticas públicas que repõem, constantemente, a desigualdade sob o discurso da inclusão; das novas relações entre Estado e os setores privados da economia, que se definem a partir das políticas públicas dirigidas ao espaço por meio de novas alianças de classe; da ausência dos espaços públicos como lugares da vida em comum e, nesse sentido, do estreitamento da esfera pública etc. Aparece sob várias formas de contestação e confrontos que vêm ocorrendo na metrópole, numa reunião potencializada pelas resistências aos processos hegemônicos. (grifos nossos)

Vemos como o sentido de segregação pode ser mais amplo e abrangente. O mais interessante do excerto acima é podermos ver, nos grifos da citação feitos por nós, como o sentido da segregação se revela a partir da resistência a ela. Mais adiante, quando realizarmos o debate mais específico sobre a ideia de resistência (e mais especificamente à ideia de 
resistência à urbanização), retomaremos esse pensamento.

Para Fabiana Valdoski Ribeiro (2014: 306), a segregação age nos planos econômico, político e social:

A segregação, e seu efeito de cisão, é necessária para superar barreiras à valorização; politicamente, fragmenta o tecido associativo para dominar, quando impede o encontro, diluindo identidades e, por fim, no nível social, desintegrando sociabilidades.

Em outro trabalho dela, ainda mais esclarecedor, vemos o mesmo raciocínio exposto acima de forma mais desenvolvida e detalhada. Segundo Fabiana Valdoski Ribeiro (2015:177):

A segregação socioespacial se transforma em processo importante para a reprodução em todos os níveis e dimensões da sociedade porque é necessário cindir, separar, impedir o uso, romper os laços de sociabilidade improdutiva, para integrar e, posteriormente, reproduzir as relações especificamente capitalistas. A segregação toca o econômico ao expulsar aqueles que são considerados barreiras à homogeneização do espaço; ao nível político, a segregação fragmenta para dominar, ao impedir o encontro e a produção de um espaço de sociabilidade para as experiências de politização e, socialmente, empobrece a vida material e imaterial dos habitantes da cidade integrando-os precariamente e impondo ao vivido uma sociabilidade baseada na lógica determinada pela propriedade privada e do consumo.

Essas dissoluções operadas pela segregação não atingem apenas os removidos, mas também os que permanecem no local. O aumento dos preços no local da comunidade removida, o BNH, apareceu nas falas de vários moradores. Segundo Pádua (2015):

A segregação se realiza também para aqueles que são moradores antigos dos lugares, proprietários de imóveis, que vivem esse processo como uma destituição de seus espaços habituais de sociabilidade, com o fechamento 
de bares, a mudança de vizinhos de longa data, o aumento do movimento de carros, a transformação das pequenas casas em espaços de consumo para a população mais abastada que chega ao lugar e aos quais a população antiga do lugar não tem acesso, em função dos altos preços. Ou seja, o lugar vai se tornando exterioridade para moradores que muitas vezes passaram a vida toda ali, e que, com a transformação do lugar, vão sofrendo um processo de destituição dos seus espaços-tempos da vida.

Segregar também é, para ela, uma estratégia espacial do Estado para evitar contestações:

A segregação seria uma forma estrategicamente elaborada pelo saber e realizada na prática pelo poder público para dominar o espaço, e desse modo, tenta impedir as contestações (...), possui um caráter político que reforça a centralização exercida pelo centro de decisões. (RIBEIRO, 2007, p. 9)

Dessa forma, os efeitos da segregação não são apenas o apartamento e a separação no espaço, pois essa é a maneira como isso se manifesta materialmente. Para os moradores do bairro novo, o motivo último pelo qual foram removidos é a necessidade de se ocultar a pobreza dos olhos da sociedade, de mandar para longe o que não queremos ver de perto. Porém, não se trata, somente, de “esconder os indesejáveis”. Em nível mais profundo, vemos que as dissoluções provocadas por ela agem em outros planos, como o da dominação política, diluição da identidade, da superação de barreiras à valorização. Destarte, a violência a que são submetidos vai além da separação apenas física no espaço, seguindo o curso uma densa espoliação urbana em diversos níveis. A espoliação urbana é aqui entendida como sendo o “somatório de extorsões que se opera através da inexistência ou precariedade de serviços de consumo coletivo que se apresentam como socialmente necessários em relação aos níveis de subsistência" (Kowarick, 1979: 59). Vinculamos segregação e espoliação por se tratarem de processos associados, embora distintos. A espoliação envolve a segregação e a contém, embora abarque outras formas de espoliar.

Produzir a periferia da forma como se produziu o novo bairro é resultado de uma lógica de centralizações, a qual possui como fundamento a tríade homogeneizaçãohierarquização-fragmentação do espaço, conforme trabalhou Fabiana Valdoski Ribeiro (2007), baseando-se na teoria de Lefebvre. Essa tríade, segundo a autora (2007: 72), possui 
a seguinte dinâmica:

O espaço mercadoria, dotado de potênciasde realização da reprodução do capital, se torna objeto de estratégias para manter as condições ideais de valorização do valor. Ele fragmenta-se pela propriedade privada mediado pelo equivalente dinheiro para acessá-lo, e homogeniza-se para se tornar isento de barreiras à reprodução do capital, bem como hierarquiza-se para dominar aquilo que não está totalmente subordinado ou continuar a manter as condições de acumulação e reprodução.

Portanto, o contexto atual nos permite afirmar que "a produção do espaço se realiza produzindo segregação sócio-espacial" (RIBEIRO, 2007:58). Nossa leitura de segregação revela-se na ampliação do conceito para além da localização física na cidade, envolvendo também a segregação como estratégia e a espoliação como o objetivo e o resultado desse processo. Dessa forma, vemos como segregar é uma prática inerente da produção capitalista do espaço urbano, que tem como fundamento a violência. É claro que essa violência da urbanização se manifesta de diferentes formas e intensidades para as diferentes classes sociais que compõem a cidade. Em nosso estudo de caso, essa violência se manifestou de forma mais visível na remoça em si, com o uso de força policial de grande truculência. Porém, ela também se manifesta de forma clara através da espoliação e da segregação. Para Renata A. Sampaio (2015:59):

A segregação socioespacial aparece a nós, portanto, na sua dimensão radical: como condição e fundamento da realização da propriedade privada da terra e da urbanização capitalista; como manifestação e resultado da violência que é própria ao processo de urbanização capitalista, que, ao não abdicar da lógica da propriedade privada capitalista como seu fundamento, repõe a expropriação e a separação como seus resultados dramáticos. (grifo nosso)

$\mathrm{O}$ argumento de Renata Sampaio é justamente a inerência da violência ao processo de urbanização. Segundo ela, "o movimento de instituição da propriedade privada capitalista - fundamento do processo de urbanização - realiza um dos sentidos de sua violência" (2015: 57). A autora vê a violência como categoria reveladora dos fundamentos da reprodução capitalista, como um dos conteúdos identitários da urbanização, embora, claro, não seja o 
único. Ela enxerga uma relação de necessidade entre propriedade privada/expropriação/violência. Para ela (2015: 58): "a violência reside não exatamente e somente nos meios e métodos empregados em tal empreitada, mas em todos os danos sociais, econômicos e políticos daí decorrentes". Mais adiante, a autora desenvolve uma relação de necessidade entre propriedade privada/expropriação/segregação. $\mathrm{O}$ fundamento do argumento dela é de que a violência é parte necessária da urbanização capitalista, baseada no valor de troca, porque a violência é imanente à troca, na medida em que a troca força a equivalência entre diferentes. Para ela (2015:70):

O processo que metamorfoseia as relações de equivalência em relações contratuais e institucionais só pode resultar, real e virtualmente, numa universalização da violência como a forma e o conteúdo das relações sociais no capitalismo, escondida sob o véu de pacificidade que cobre a figura do contrato. (grifo da autora)

Conforme já mencionado no começo desse trabalho, mesmo as classes mais ricas da sociedade não podem fugir dos problemas urbanos, estes também resultados da violência urbanização. Porém, nossa noção de violência urbana não se resume apenas à ideia de criminalidade. Talvez até em sentido mais importante, vemos que a violência do valor de troca não permite a realização das pessoas como seres humanos criadores, no sentido lefebvriano de obra. Estão sujeitados a uma lógica de consumo que, embora acessem de maneira privilegiada em relação a muitos outros, não os tira do totalitarismo do consumo. Estão expostos, ainda, à violência das relações de troca. Novamente, cabe aqui uma analogia com o profícuo debate de Robert Kurz (2000) sobre a dominação sem sujeito: mesmo os mais ricos são escravos do tempo acelerado da modernidade, da abstração do relógio, da mediação de relações sociais concretas pela abstração do valor e da mercadoria. Assim, a violência da urbanização está posta como generalidade na cidade capitalista, variando em níveis e dimensões entre as diferentes classes. Seus processos desumanizantes atingem a todos, de diferentes formas, tornando-nos menos humanos (no sentido criador de "obra") ao morarmos na cidade capitalista. Evidentemente, essa violência atinge níveis absurdos e consequências mais dramáticas quando falamos da parcela mais pobre dos moradores da cidade. Porém, indo dos níveis mais brandos até os mais extremos, encontramos resistências a esse processo. 


\section{2. - Resistências}

Diante do exposto até agora, vimos que a violência é parte inerente do processo de urbanização. Todavia, ela não se manifesta da mesma maneira para todas as classes socias pois, como vimos, os moradores da comunidade removida, seja os que foram para o bairro novo na periferia, seja os que foram para a ocupação, estão sujeitos à face mais violenta e espoliativa do processo de urbanização. Nos dois casos, essa violência e espoliação os submete à situação de urgência e necessidade, o que coloca a resistência como condição necessária de existência. É evidente que ela ocorrerá em graus variados e de formas distintas no bairro novo e na ocupação, assim como era diferente quando eles ainda moravam na comunidade.

No caso da ocupação, fica mais claro que estávamos diante de um movimento que se constitui como resistência. Ela subverte a solução do bairro novo e aponta uma recusa em aceitar a condição segregada de distanciamento. Fica evidente a inserção da ocupação no contexto local dos movimentos de luta por moradia e a aproximação com grupos políticos organizados, como o grupo encabeçado por Cosme Vitor, já mencionado como liderança externa da ocupação. Essa experiência permitiu aos membros da ocupação um aprendizado e uma formação política que enquadram uma forma de consciência sobre o processo vivido por eles (o que aparecia até no vocabulário mobilizado por eles durante as entrevistas, pois era evidente o domínio de um linguajar bem próprio de outros movimentos sociais, como o MST). No entanto, não podemos nos deixar levar pela falsa ideia de que apenas a ocupação representava resistência, enquanto no bairro novo as pessoas simplesmente aceitaram passivamente a solução imposta. A ocupação realizava-se como uma situação de provisoriedade da habitação que, na visão de muitas famílias removidas, inviabilizava essa forma de resistência. A possibilidade da casa permanente no bairro novo, ainda que distante, era contraposta ao modo provisório de moradia da ocupação, o que fez com que muitos não quisessem aderir ao grupo dos ocupantes. Porém, isso de maneira alguma os fez aceitar passivamente o processo violento que viveram. Sua resistência apenas assumiu outros contornos.

Cosme Vitor representou, em alguma medida, um elo entre essa população dispersa e dividida entre os que aderiram ao programa e os que decidiram por ocupar, aglutinando pautas e interligando pessoas. Suas idas e vindas entre ocupação e bairro novo eram muitas vezes a forma de contato possível entre os antigos moradores da comunidade removida. Portanto, mesmo no bairro novo houveram pessoas articuladas ao processo político de luta 
por moradia que orbitava em torno dos membros da ocupação e contatos entre ocupantes e moradores do Jardim São José II eram feitos, principalmente entre os que eram amigos na comunidade Morro do Regaço antes da remoção.

No bairro novo, as soluções para o distanciamento foram inúmeras: um exemplo interessante é a crítica inicial dos moradores à ausência de mercados baratos no bairro. Fazer compras exigia deslocamentos muitas vezes mais caros do que a própria comida. $\mathrm{O}$ desenvolvimento de um circuito de comércio de alimentos à baixo custo, hoje realidade no bairro novo, representa uma solução a esse isolamento relativo a que estão submetidos.

A Associação de Moradores do Jardim São José II, embora alvo de críticas por parte de alguns moradores e do próprio Cosme Vitor, não deixa de representar uma tentativa de movimento reivindicatório junto aos órgãos do poder público por melhorias no bairro (a pauta principal da associação é o aumento no número de linhas de ônibus para lá). A luta contra a violência policial no bairro, da qual Cosme Vitor também é ativamente participante (conforme vimos anteriormente) representa uma maneira de transformar as relações com o poder público.

Por fim, podemos citar a prática comum entre os jovens do bairro, durante as horas mais avançadas da noite e principalmente aos fins de semana, de pular as catracas dos ônibus para poderem se locomover pelo resto da cidade. Portanto, embora no bairro novo não tenhamos essa resistência organizada vinculada a um projeto político mais claro, essas sequências de pequenas transgressões diárias e de pequenas soluções para problemas práticos do cotidiano não podem ser enquadradas fora do âmbito da resistência.

Para definirmos melhor nossa ideia de movimentos de resistência à urbanização, vamos empreender aqui uma discussão teórica sobre os pontos mais relevantes que fundamentam nosso pensamento. Começamos por discutir a relação entre transgressão e resistência, como o faz Fabiana Valdoski Ribeiro (2012), de modo a definir melhor os conteúdos desta última:

A transgressão, compreendida nos termos apresentados por Henri Lefebvre, é considerada um elemento revelador das imposições e expropriações sobre os moradores, que necessitam a todo momento transgredir para manterem a reprodução de suas vidas. Em outro patamar estão as resistências. Elas se alargam na compreensão ao situar um conjunto de reivindicações que tática e estrategicamente podem abrir caminho ao projeto daquilo que atualmente aparece como impossível. A 
resistência se fará sob aspectos distintos em cada país conforme a formação histórica. Os mecanismos de expropriação, exploração e espoliação produzem uma prática socioespacial distinta na luta social e política pelo espaço.

A transgressão vincula-se ao movimento tendencial de contestação (e em alguns casos, a contestação como única opção de sobrevivência) enquanto a resistência está no plano das táticas e estratégias inseridas em um projeto político e social mais amplo. Ambas compõem as formas de luta em graus variados, conforme o caso. Nesse trabalho, resistência e transgressão, no sentido usado pela autora, serão agrupadas genericamente sob o termo resistências, ainda que se reconheça a possibilidade ou não de haver um projeto político definido. Ainda segundo Fabiana Valdoski Ribeiro (2007, 2012:15):

A potência de ambos os conceitos, resistência e transgressão, reside no fato destes conterem os conflitos, latentes ou não, da reprodução da sociedade em sua totalidade, as formas distintas de apreensão de elementos para esta reprodução pelas classes que a compõem, com seus jogos de estratégia e ações, que se revelam concretamente em práticas sócio-espaciais.

Portanto, podemos construir uma hipótese de leitura sobre a ocupação que permita vislumbrar um movimento maior em direção à totalidade, que evidencie estratégias, lógicas e práticas espaciais que nos aproximam dos conteúdos sobre os quais pretendemos refletir.

Nossa primeira questão para essa resistência é: de onde ela surge? Seria ela um resultado direto (e até, no limite, um resultado lógico) da expropriação generalizada imposta pelo capital? Uma reação que necessariamente aparecerá, estando contida e pressuposta na imposição? Algo completamente exterior ao capital que se manifesta em reação a ele? Seria ainda algo intrínseco e natural do ser humano diante de opressões? Segundo Fabiana Valdoski Ribeiro (2017: 151):

Ao mesmo tempo em que vivemos um aprofundamento da alienação da sociedade em relação a uma de suas maiores obras, que é a cidade, contraditoriamente, emerge a resistência como prática socioespacial necessária para a reprodução da vida no urbano. É no desenrolar desta última que se abrem as possibilidades da consciência sobre a expropriação nos vários níveis da vida, revelando, entre luzes e sombras, a crise urbana, 
o papel do espaço na contemporaneidade e a negação do direito à cidade.

Para a autora, a resistência parece ser produto da própria opressão (o que não exclui todas as outras possibilidades). Em outro texto (2007:83) vemos isso de forma mais clara:

As transgressões dos sujeitos são compreendidas como parte do processo, que nega, em diferentes intensidades, a opressão e a repressão da ordem distante, para que eles possam realizar, ainda que precariamente, os projetos, frutos das experiências provenientes de sua história particular.

A resistência é parte do processo que nega a opressão. Vemos aqui a relação entre a opressão e o surgimento da resistência, afinal quem resiste sempre resiste a algo. Contudo, a opressão não é vista como a única fonte, pois senão não poderíamos explicar lugares oprimidos e que não levantam resistência. A opressão, contudo, oferece possibilidades de tomada de consciência da exploração (por meio da instância do cotidiano) e, desta maneira, ampliando também as possibilidades de resistência.

Apropriando-nos da definição de Fabiana Valdoski Ribeiro (2017: 156), assim entendemos a resistência:

A resistência é vista nesta reflexão num sentido lato sensu, isto é, não se restringe a um ato imediato de recusa à expropriação, da permanência de algo em si, mas se amplia ao compreendê-la como um conjunto de ações que denuncia uma prática vinculada ao domínio sobre o espaço em detrimento da apropriação. Vista dessa maneira, ela é considerada o germe de um projeto de cidade vinculada não somente à permanência de algo que pode perder-se, mas pode tratar-se do princípio de um projeto que tenta retomar a apropriação, a identidade em bases coletivas, com o objetivo de superar a prática do consumidor do espaço para aquele que se reconhece como sujeito produtor de um bem comum. (grifo nosso)

Um destaque a se fazer da citação anterior é sobre nosso grifo: a ideia de resistência não envolve necessariamente algo que ainda não foi cooptado e vai se perder. Ela pode envolver também um novo projeto de (re)apropriação do uso, algo que possa superar uma determinada prática espacial, aquela do consumidor do espaço.

Destarte, a resistência possui o que poderíamos chamar de um duplo aspecto: ela 
possui, por um lado, um papel no presente, uma inserção na conjuntura, um atuação no enquadramento das forças políticas em disputa, sua ação como movimento social; por outro lado, aponta também para o futuro, para um projeto de sociedade e de cidade. Por conseguinte, ela contém o "germe" da superação das condições sociais vigentes. Isso nos aproxima do debate lefebvriano sobre o método progressivo-regressivo, no qual o papel do utópico pode ser vislumbrado, pois a utopia para o autor possui um aspecto real por estar gestada no presente e posta para nós como objeto virtual. Concluímos daí uma importância enorme da resistência em um horizonte de superação do que está posto. Lembramos também que, para Lefebvre, o mundo da mercadoria não é uma generalidade absoluta e existem elementos que não fazem parte do processo geral do capital. Entendemos que, para ele, se houver resistência ao capital que seja encarada como não "repositora", ela está inclusa em algum patamar ou em algum de seus aspectos nesse mundo exterior que escapa ao capital, ainda que dele seja produto em alguma medida.

Existem outras condições e fatores que precisam ser levados em conta na origem da resistência. Um deles diz respeito à identidade. Fabiana Valdoski Ribeiro (2017: 156), apropriando-se das reflexões de Mauro Iasi, coloca a importância da revolta contra a injustiça ser partilhada por um grupo em torno do qual se cria uma identidade em relação à expropriação. Essa identidade parece ser uma variável muito relevante se pensarmos no contexto de nossa remoção aqui analisada. Os moradores da ocupação se mantiveram juntos e construíram de maneira intensa uma identidade coletiva com base nas antigas relações de vizinhança e no compartilhamento da violência da remoção. A identidade se constrói no plano da ação, não em algo produzido pelo subjetivo, mas na prática cotidiana. No bairro novo Jardim São José II, embora aja algum fundo comum no histórico de violência sofrida, a questão da identidade não se constituiu de maneira efetiva e não resultou em uma movimentação política que aglutinasse o bairro em uma reivindicação conjunta em torno de pautas comuns a todos. Ainda sobre a constituição da identidade, Fabiana Valdoski Ribeiro (2007:19) diz:

Neste processo de urbanização, que traz uma enorme produção material, produz-se igualmente novos valores, além de códigos morais, políticos e éticos renovados. Porém, isso ocorre sem conseguir excluir a identidade concreta que se constrói através da apropriação dos lugares por meio dos usos, na qual o homem se reconhece, mesmo que essa apropriação se realize de forma residual e precariamente. 
A partir desse trecho, conseguimos reter mais alguns pontos de interesse para nossa análise. O primeiro é a relação entre identidade coletiva, resistência e apropriação pelo uso. O segundo é a discussão sobre a relação entre essa "forma residual" e a resistência, discutida mais adiante. Ainda segundo a autora (2016:02):

Esta naturalização que compõe a consciência social subalterna ao capital revela-se como tendência e não se realiza em plenitude. Lefebvre diz que 'o círculo não consegue fechar-se', isto é, há fissuras decorrentes dos conflitos incessantes das contradições entre a produção socializada e a apropriação privada dada no interior da expropriação. Surgem resistências em vários níveis e de diversos modos. Elas podem ser vistas em grande parte nas cidades, desde ocupações de praças, de prédios até intervenções artísticas apropriando-se do espaço. Há outras resistências, vistas como transgressões cotidianas subvertendo normas, que não são evidentes, mas que se realizam no dia a dia da população e são, igualmente, resultado das expropriações, como o não pagamento do transporte público, uso de espaços controlados etc.

Existe uma tendência de totalização do capital, mas ela não se realiza. O círculo não fecha. Por quê? Essa é justamente nossa próxima questão. Discutiremos a frente, à luz do conceito de Zona Autônoma Temporária (TAZ), o papel dessas "fissuras" citadas pela autora e que também aparecerão adiante em textos de Lefebvre e outros autores. Nossa preocupação agora é em entender o que explica o círculo não se fechar e qual o papel do resíduo nisso. Nas palavras de Henri Lefebvre (1999: 41):

Tudo se torna calculável e previsível, quantificável e determinável. Tudo deve integrar-se numa ordem (aparente e fictícia) fortalecida pelas coações. Tudo, salvo um resíduo de desordem e de liberdade, às vezes tolerado, às vezes perseguido com uma terrível fúria repressora.

Até agora parece constatável que, para esses autores, o círculo não fecha e o capital não totaliza. O que parece sempre estar por fora é o resíduo, cuja natureza ainda não está totalmente clara. Seria a resistência o resíduo? Seria algo além (ou aquém) do resíduo? Ela conteria o resíduo? Seria por ele contida? Para cercar melhor essa questão, vejamos mais um 
trecho de Fabiana Valdoski Ribeiro (2007:172-173):

A vida constantemente está sendo programada pelas determinações impostas pelo urbano e, deste modo, se acelera implodindo relações de vizinhança, de cooperação, de coletividade e tantas outras que nos projeta a enriquecer a relação com o outro. $\mathrm{O}$ produto deste processo é o empobrecimento do humano. Todavia, ao nos debruçarmos sobre as próprias formas de dominação descobrimos, mesmo residualmente, as trangressões que nos encaminha as apropriações do espaço. Verificamos que o espaço-tempo da vida não foi plenamente cooptado pela relações de troca, mas que em meio às formas de alienação, que insistem em se apossar de todo o plano de nossas vidas, propomos maneiras de se contrapor a tendência hegemônica. Compreendemos que aqui reside a 'fissura', a fenda que não permite o círculo capitalista cerrar, e sim, se coloca enquanto barreira a ser transposta pelo próprio capital.

Nos termos colocados pela autora, percebemos novamente a importância das fissuras, agora postas como o que explica o não fechamento do círculo. Elas são as transgressões ou elas residem nas transgressões. De ambas as formas, elas parecem ser um diálogo claro com o que Lefebvre chamou de resíduo de desordem e liberdade. Segundo a autora, "as fissuras permanecem. Ali reside o negativo, ali estão as resistências" (2015:172).

Entendemos aqui que ambos apontam para o resíduo como o estágio "larval" da resistência, sua potencialidade máxima que pode vir a se tornar transgressão e/ou resistência, sendo ele um produto contraditório do capital por derivar em alguma medida da própria opressão. Se pensarmos o caso da ocupação da estação de trem, um argumento a esse favor reside no fato de que ela só existe em função de um movimento homogeneizante da parte do Estado, o que a torna produto de um processo do capital em alguma medida. Se um fenômeno for fruto de um processo capitalista, como a ocupação foi fruto da remoção de certa forma, isso significa que tudo aquilo que se manifestar em termos espontâneos de resistência e de potencial humano ainda assim são definidos nos termos do mundo da mercadoria? Achamos insuficiente que esse argumento inclua toda a ocupação - todos os seus aspectos e práticas, tudo aquilo que revela e coloca como horizonte - como integrante e repositor do status social vigente. Mesmo parcialmente dentro do processo, a resistência pode apontar ou tornar manifesto um aspecto que não seja interno ao processo, nem seja por ele definido, algo realmente fora do mundo da mercadoria. Os dois autores mais presentes nesse ponto da 
discussão, Lefebvre e Fabiana Valdoski Ribeiro, apontam para algo mais profundo que não diz respeito ao capital, algo que seria impossível de cooptar, algo que seria irredutível e, portanto, sempre estaria presente. Vejamos como isso aparece em Fabiana Valdoski Ribeiro (2017: 154):

A consciência entre ser consumidor do espaço e ser criador da obra chocase na prática socioespacial. Há irredutíveis. 'O conflito não aparece sempre nem é dito, Evita-se falar dele e torna-lo manifesto. Mas ele está aí, constante, latente, implícito'. Um mal-estar (aspecto da crise urbana) aparece desse conflito e emergem reações diversas (...). A consciência dessa sucessão de expropriações pode emergir do mal-estar, da privação extremada em determinado espaço-tempo e da opressão levada a cabo pela rigidez das normas e funções.

O que seria esse irredutível? Algo que não pode ser reduzido pelo capital e sua homogeneização, algo único. A autora chega a colocar que "as contradições continuam vivas já que o irredutível está presente" (2016:8), dando lugar de destaque ao irredutível, como podemos ver a seguir (2016:17):

Mesmo que experiências de resistências como as que apresentamos estejam entre luzes e sombras, elas contêm os irredutíveis e movem a consciência daqueles que estão envolvidos nas práticas cotidianas de luta contra a integração do espaço à lógica do capital.

Ela vê a resistência como um dos termos irredutíveis da relação de poder constituinte das relações em geral. Para ela (2015:178):

A segregação contém o negativo como algo intrínseco a um jogo de relações no qual estão presentes estratégias. A segregação, por sua vez, carrega o negativo no irredutível do viver. A relação dialética entre segregação e resistência descobre no momento mesmo em que o conflito emerge.

Podemos aproximar parte do conteúdo desse irredutível observando o sentido de alguns conceitos para Lefebvre que parecem conter alguns de seus aspectos: obra e criação; 
cotidiano, em sua relação com espontaneidade; apropriação e uso; diferença, como contraposição ao homogêneo; momentos, da teoria lefebvriana dos momentos. Todos parecem conter parcialmente algo muito mais próximo da concretude humana do que da abstração generalizada do capital. Para Lefebvre (1999:82):

Em toda parte existem falhas, vazios, lacunas. E conflitos, inclusive os existentes entre as lógicas e as estratégias. A lógica do espaço, submetida às exigências do crescimento, a lógica do urbanismo, a do espaço político e da moradia, entrechocam-se, às vezes se espatifam uma contra a outra. $\mathrm{O}$ mesmo acontece com a lógica das coisas (objetos) e a do jogo (ou dos jogos). As lógicas sociais situam-se em diferentes níveis, entre elas persistem ou se aprofundam fissuras. Pelas fissuras passa o desejo. Sem o que, a "matéria humana", informe, logo seria sujeitada a uma forma absoluta, garantida e controlada pelo Estado solidamente apoiado na massa dos "sujeitos" e "objetos". Sem o que, a cotidianidade uniformizar-se-ia inapelavelmente. Até a subversão tornar-se-ia impensável. (Grifo nosso)

As fissuras, que discutimos anteriormente, permitem a passagem de um desejo, sem o qual uma "matéria humana" seria submetida, tornando a subversão impensável. De que desejo fala o autor? Vejamos um trecho mais esclarecedor de Lefebvre (2001:105), no qual ele fala sobre as necessidades antropológicas:

A essas necessidades antropológicas socialmente elaboradas (isto é, ora reunidas, aqui comprimidas e ali hipertrofiadas) acrescentam-se necessidades específicas, que não satisfazem os equipamentos comerciais e culturais que são mais ou menos parcimoniosamente levados em consideração pelos urbanistas. Trata-se da necessidade de uma atividade criadora, de obra (e não apenas de produtos e de bens materiais consumíveis), necessidades de informação, de simbolismo, de imaginário, de atividades lúdicas. Através dessas necessidades específicas vive e sobrevive um desejo fundamental, do qual o jogo, a sexualidade, os atos corporais tais como o esporte, a atividade criadora, a arte e o conhecimento são manifestações particulares e momentos, que superam mais ou menos a divisão parcelar dos trabalhos. (Grifo do autor)

Percebemos que existe algo desse irredutível muito próximo do resíduo, ou 
contendo/sendo contido por ele, manifesto no cotidiano, na espontaneidade e na arte de transgressão. Pelo apresentado até o momento, a resistência não é uma característica ontológica, mas surge como produto do processo contraditório do capital. Apresentamos abaixo, todavia, um conjunto de apontamentos para complexificar essa questão e trazer mais elementos para o debate. Pretendemos aqui debater de forma mais adensada os aspectos da resistência e seus elementos, intrínsecos ou não. Do que foi visto até agora, temos claro que a resistência faz parte do processo em alguma instância e que ela contém algo irredutível dentro dela, mas não se confunde com ele. Vejamos a leitura de Ana Fani Carlos (2015:34) sobre Fabiana Valdoski Ribeiro:

No plano social, a vida cotidiana subsumida à lógica da acumulação e normatizada traz em si seu outro: a resistência e, com ela novas formas de lutas. Fabiana Valdoski Ribeiro, ao direcionar sua compreensão aos desdobramentos da relação uso/troca, ilumina o movimento do processo de produção do espaço urbano no qual a hegemonia do valor de troca sobre o uso, normatizando-o e subsumindo a vida, aponta para seu outro. Ou seja, na produção do espaço há um conflito de estratégias e, portanto, uma relação de poder, que, intrinsecamente, contém a resistência, seja ela visível ou não. (...) No entanto essa resistência não é pura, pois se por um lado ela coloca as contradições espaciais em outro patamar, por outro, pode ratificar fundamentos da produção capitalista do espaço.

Colocada nesses termos, a resistência oferece a possibilidade de aflorar o irredutível. Isso é importante para explicar, por exemplo, porque as outras remoções não resultaram igualmente em ocupações. A opressão não gera a certeza da resistência, mas oferece possibilidades: constituição de uma identidade coletiva baseada no histórico de violência sofrido de maneira conjunta; tomada de consciência da exploração e das injustiças sociais; uma pauta de reivindicações conjunta e inserção em um movimento político mais amplo. $\mathrm{O}$ surgimento de um movimento contrário à homogeneização é bem desenvolvido por Lefebvre. Segundo o autor (2006:44):

Pode-se mostrar que o espaço abstrato tem contradições específicas; essas contradições do espaço procedem, em parte, de antigas contradições oriundas do tempo histórico, modificando-as: ora agravando-as, ora atenuando-as. Entre essas antigas contradições nascem novas, que 
eventualmente conduzem o espaço abstrato em direção ao seu fim. No seio desse espaço a reprodução das relações sociais de produção não se consuma sem um duplo movimento: dissolução de relações, nascimento de novas relações. De modo que o espaço abstrato, em que pese sua negatividade (ou melhor, em razão dessa negatividade), engendra um novo espaço, que terá o nome de espaço diferencial. Por quê? Porque o espaço abstrato tende para a homogeneidade, porque ele reduz as diferenças (particularidades) existentes, e porque o espaço novo só pode nascer (ser produzido) acentuando as diferenças. Ele reunirá o que o espaço abstrato separa: as funções, os elementos e momentos da prática social. (grifo do autor)

O autor coloca o processo de homogeneização do capital como o avanço do espaço abstrato, instrumental, coercitivo e dotado de potência redutora do vivido. Contudo, esse avanço não se totaliza por causa das contradições do espaço. Contradições específicas do próprio espaço abstrato e outras relativas ao espaço produzido socialmente na modernidade se elevam nos dias atuais a outro patamar mais elevado e central e, embora o espaço abstrato atue nesse sentido, ele nunca consegue apagar ou resolver as contradições do espaço. Temos, destarte, diante de nós um espaço contraditório como sendo o segundo polo da relação com o espaço abstrato, seu par dialético. A tríade mobilizada pelo autor para tratar essas contradições é composta por: espaço abstrato - espaço contraditório - espaço diferencial, na qual o terceiro termo da tríade está apontando para o horizonte de superação que constitui algo novo, mas não necessariamente definido nos termos da contradição anterior. Vejamos a causa dessa não totalização do espaço abstrato para o autor (2006:46):

A luta de classes? Ela intervém na produção do espaço, produção da qual as classes, frações e grupos são os agentes. A luta de classes hoje mais do nunca, se lê no espaço. Para dizer a verdade, só ela impede que o espaço abstrato se estenda ao planeta, literalmente apagando as diferenças; só a luta de classes tem uma capacidade diferencial, a de produzir diferenças que não sejam internas ao crescimento econômico considerado como estratégia, "lógica" e "sistema" (diferenças induzidas ou toleradas). As formas dessa luta são muito mais variadas que outrora. Dela fazem parte, certamente, as ações políticas das minorias. 
Deste modo, percebemos de forma mais contundente que, para o autor, a resistência é de certa forma o que impede esse fechamento do círculo. Portanto, a luta de classes não seria consequência da não totalização posta como impossível, mas sim a não totalização devido à luta de classes, posta como um motor de mudanças sociais do campo das possibilidades. Estas últimas são ampliadas diante de um contexto de exploração como a remoção, mas continuam no plano das possibilidades. Caso inexistam lutas sociais em meio ao avanço do espaço abstrato, as diferenças podem vir a desaparecer em um determinado contexto local e específico. Vejamos como para o autor (2006:13; cap.VI) isso ocorre:

As diferenças se mantêm ou começam à margem da homogeneização, seja como resistências, seja como exterioridades (o lateral, o heterotópico, o heterológico). O diferente é primeiro, o excluido: os periféricos, as favelas, os espaços dos jogos proibidos, os da guerrilha e das guerras. Cedo ou tarde, entretanto, a centralidade existente e as potências homogeneizantes absorvem as diferenças, se elas permanecem na defensiva e não passam ao contra-ataque. Então a centralidade e a normalidade mostram os limites de sua capacidade de integração, de recuperação ou de eliminação daquilo que transgride.

Vemos a importância das lutas sociais (lutas pelo espaço e por meio do espaço) avivando o uso. Essas lutas podem ser vistas com um desempenho ativo na produção do espaço. Tentamos apontar a possibilidade de uma leitura que coloque a resistência fora de um patamar ontológico, mas dentro de um quadro de atuação imprescindível para a atualidade. Vemos ainda no texto que, além das resistências - produtos em alguma medida do processo homogeneizante - abrem-se também as exterioridades marginais ou não ao capital (não importa, pois não de define em função de seus limites negativos). As questões das fissuras, e das decorrentes resistências e estratégias, serão debatidas por meio do conceito de TAZ. Por ora, podemos adiantar que cada espaço que permite a transgressão e a resistência, cada ponto cego na fiscalização supostamente onipresente do Estado, é uma fissura passível de abrir possibilidades de contestação. É o caso dos espaço vazios que são ocupados por movimentos sociais, como a antiga estação de trem no centro de São José dos Campos. 


\section{3. - TAZ}

Nesse tópico, vamos explanar melhor do ponto de vista da utopia experimental os espaços "bem sucedidos" ou "favoráveis à felicidade" de que falou Lefebvre. Foi necessária a explicação do conceito de TAZ, pouco conhecido nos circuitos acadêmicos, como tentativa de iluminar a leitura das ocupações urbanas. Não se trata aqui de afirmar que a TAZ e as ocupações urbanas são exatamente iguais, mas sim de trazer o conceito de TAZ para refletir sobre como a resistência à urbanização utiliza-se das brechas e fissuras (discutidas anteriormente em textos de Lefebvre e mais debatidas à frente sob a ideia da TAZ) para resistir. Ao mesmo tempo, a resistência à urbanização, de certa forma, também cria e recria essas brechas e fissuras que serão potencialmente utilizadas como formas de insurgência à lógica do Estado capitalista.

Em um primeiro momento, contrapomos a TAZ ao conceito de liberdade e autonomia defendido pela chamada Teoria Crítica da escola de Frankfurt (da qual me aproprio especificamente de Horkheimer), para a qual autonomia seria, grosso modo, apenas uma forma de consciência fetichista. Mais à frente, contrapomos TAZ a outros dois conceitos (situação, dos situacionistas, e momentos, de Lefebvre) para neles enxergar uma convergência possível e iniciar um breve debate possível sobre o conteúdo desse fenômeno moderno de resistência.

Trazemos os pontos principais do livro Zona Autônoma Temporária, de Hakim Bey, de forma a expor seus principais argumentos. Veremos que eles se aproximam muito de algumas passagens de Lefebvre e outros autores. Embora os argumentos possuam força e embasamento, Hakim Bey não os explora até o limite de seu desenvolvimento pois, repito, não é um livro acadêmico. O que ele possui em termos de bons argumentos, peca por escolher exemplos ruins que, muitas vezes, buscados poeticamente na história, não revelam de fato a potencialidade da TAZ para leitura dos conflitos atuais do espaço urbano.

Em sua amplitude conceitual, toda uma geografia seria possível de se desdobrar a partir da TAZ e no seu movimento com os outros conceitos, mas tal pretensão escapa ao pretendido nesse trabalho. Almeja-se, antes, indicar uma via possível de investigação e discussão para a Geografia.

Toda minha pesquisa e minhas especulações cristalizaram-se em torno do conceito de ZONA AUTÔNOMA TEMPORÁRIA (daqui por diante 
abreviada por TAZ). Apesar de sua força sintetizadora para o meu próprio pensamento, não pretendo, no entanto, que a TAZ seja percebida como algo mais do que um ensaio ("uma tentativa"), uma sugestão, quase que uma fantasia poética. Apesar do ocasional excesso de entusiasmo da minha linguagem, não estou tentando construir dogmas políticos. Na verdade, deliberadamente procurei não definir o que é a TAZ - circundo o assunto, lançando alguns fachos exploratórios. No final, a TAZ é quase autoexplicativa. Se o termo entrasse em uso seria compreendido sem dificuldades... compreendido em ação. (BEY: 1990, p. 12)

O conceito de TAZ envolve ação e consciência, teoria e prática, uma proposta concreta e uma utopia, um sentido do possível e ao mesmo tempo algo real e concreto. A TAZ é uma forma de liberdade possível, uma crítica a forma tradicional da palavra revolução, um elogio ao levante espontâneo. Aqui, analisaremos o conceito de TAZ tentando compreender seus limites e possibilidades, segundo os argumentos do autor, para explicação dos movimentos contemporâneos em busca de autonomia e emancipação, como no caso das ocupações urbanas.

A chave para o conceito de TAZ reside em uma concepção muito específica de liberdade:

Estamos nós, que vivemos no presente, condenados a nunca experimentar a autonomia, nunca pisarmos, nem que seja por um momento sequer, num pedaço de terra governado apenas pela liberdade? Estamos reduzidos a sentir nostalgia pelo passado, ou pelo futuro? Devemos esperar até que o mundo inteiro esteja livre do controle político para que pelo menos um de nós possa afirmar que sabe o que é ser livre? Tanto a lógica quanto a emoção condenam tal suposição. A razão diz que o indivíduo não pode lutar por aquilo que não conhece. E o coração revolta-se diante de um universo tão cruel a ponto de cometer tais injustiças justamente com a nossa, dentre todas as gerações da humanidade. Dizer "só serei livre quando todos os seres humanos (ou todas as criaturas sensíveis) forem livres", é simplesmente enfurnar-se numa espécie de estupor de nirvana, abdicar da nossa própria humanidade, definirmo-nos como fracassados. (BEY: 1990, p. 12) 
A questão da liberdade e autonomia na TAZ é particularmente efetiva para realizar um diálogo com a Teoria Crítica. Vejamos como aparece isso em um dos expoentes da escola Crítica: Max Horkheimer. A título de exemplo, analisaremos a forma como aparece a ideia de autoridade e, consequentemente, a ideia de autonomia ainda que vista na forma de negativo da autoridade. Para essa linha, liberdade e autonomia são dois conceitos que não passam de uma forma de consciência fetichista, necessária ao capitalismo, porém ilusória de um ponto de vista concreto. Para tal argumento, o autor fundamenta-se em uma forma de autoridade generalizante na sociedade.

O conceito de autoridade é colocado por Horkheimer em posição de alta importância, bem como sua interface com a cultura. No texto Autoridade e Família (Horkheimer, 1936) o autor trabalha a autoridade em diversos períodos históricos, na maneira como se fundam as relações de dominação e subordinação no interior de cada sociedade, assim como as diversas formas que emergem no plano da aparência. Um enfoque especial é dado às relações com o conceito de cultura, destaque para ele, mostrando não só as formas de imposição, mas também formas de aceitação da coação. Na relação entre cultura e autoridade, a questão passa a ser de que forma a cultura aparece como interiorização das coerções, ou mesmo como mantenedora de opressões: "não era apenas a coação que mantinha essas ordens, mas os próprios homens aprenderam a acatá-las" (1936:192).

Horkheimer aponta os vários sentidos e formas que autoridade pode assumir, incluindo uma subordinação que seja do próprio interesse do subordinado, como uma criança que recebe boa educação, por exemplo. Essa situação pode ser vista como condição do desenvolvimento das potencialidades humana. Contudo, ao implicar alguma privação aos dependentes ou manutenção de relações retrógradas, pode também ser o empecilho para o desenvolvimento humano de maneira geral:

"Portanto, a autoridade como dependência aceita pode significar tanto condições progressistas, favoráveis ao desenvolvimento das forças humanas, correspondentes ao interesse dos participantes, quanto um conjunto de relações e ideias sociais sustentadas artificialmente e há muito falseadas que contrariam os interesses reais da comunidade." (1936:193). 
A autoridade é entendida como uma relação, uma subordinação ao outro mediante uma superioridade objetiva, seja ela física ou econômica. Por isso o destaque ao papel da autoridade na família, posta por ele como uma "escola de autoridade", construindo a autoridade nas estruturas de pensamento, nos sistemas de trabalho, de socialização, ainda que apareçam aos seus membros como sua livre escolha. A ordem hierárquica, segundo ele, atua na formação psíquica dos indivíduos, mimetizando a ordem social. É claro que a esfera econômica é importante, mas nessa análise sobressaem ainda as determinações culturais e psíquicas fundantes da autoridade, trazendo novas variáveis para o debate. Daí poderia derivar-se, por exemplo, o raciocínio do autor de que a estrutura autoritária da família é uma das componentes do Estado autoritário, é posta como um de seus alicerces, sustentando mais do que apenas uma estrutura puramente econômica.

Nesse contexto de dominação a liberdade só poderia existir como "concordância formal entre realidade externa e decisão própria" (1936:196). A própria aceitação da realidade como um fato dado, que aparece como livre escolha para o indivíduo, é posta por Horkheimer como forma mascarada da autoridade. Quando "as próprias condições se tornaram autoritárias" (1936:199) a libertação significa para o indivíduo apenas estar entregue à própria sorte diante de uma realidade com a qual deve conformar-se. No sistema capitalista produtor de mercadorias, isso significa ao indivíduo estar livre para ser explorado pelo mundo do trabalho, sob formas de coação que lhe aparecerão como fruto de sua livre escolha combinada com a realidade inexorável do mercado. O mundo moderno parece apontar que "circunstâncias da realidade aparecem como simples fatos que não cumprem nenhum fim, mas têm de ser aceitos" (1936:199). A impotência do indivíduo emerge diante de uma realidade que lhe aparece como totalmente caótica, sobre a qual não tem pleno entendimento em na qual não se vê como atuante.

Na lógica moderna capitalista, mesmo o que aparece como virtude e liberdade de decisão sofrem, sem que se perceba, o enquadramento da lógica generalizada de dominação, ainda que de formas específicas. A liberdade de escolha é condicionada de tal maneira que, apesar de aparecer como liberdade, não leva em conta que as alternativas a serem escolhidas foram postas socialmente e que, caso não se decida segundo uma lógica preexistente o indivíduo não se reproduz enquanto organismo vivo, ou membro de determinada classe social, posição, etc. Destarte: 
O lugar do despotismo não foi eventualmente ocupado pela liberdade, mas pelo cego mecanismo econômico, um Deus anônimo que escraviza os homens e a quem invocam aqueles que, se não têm poder sobre ele, têm pelo menos o benefício dele. Os donos do poder cessaram de agir como representantes de uma autoridade e tornaram-se, portanto, funções da legitimidade de suas fortunas. (1936:202).

Vemos, portanto que mesmo os membros da classe dominante ainda são escravizados por uma lógica de vida segundo a qual precisam, necessariamente, se enquadrar para se reproduzirem enquanto tal. $\mathrm{O}$ empresário que aparece como de livre iniciativa está sujeito à lógica econômica: ele não decidirá preços, muito menos o que irá produzir e como. Tudo será decidido no âmbito do mercado, que para ele aparece como entidade autônoma: devese apenas respeitar a autoridade dos fatos econômicos. Da mesma forma, o consumo aparece como liberdade de escolha, mas apenas nas formas de consumir, nunca sendo questionada a forma consumo ou as determinações sociais de uma inserção na hierarquia de acesso ao consumo.

No plano psicológico, mesmo suas concepções estarão balizadas pela maneira vigente de pensar, como na "idolatria do próprio sucesso, este Deus do mundo moderno". Até mesmo seu gozar da fortuna e suposta liberdade ainda é escravizada por um ritmo de vida consumista (vida mediada apenas pelo consumo) e abstrato (no sentido de tempo abstrato). O trabalho é posto como realidade a todos - ainda que esse trabalho seja gerenciar uma fortuna, ele não poderia ser usado apenas como ócio criativo, ele precisa ser também tempo de trabalho, não há escolha livre, mas antes uma forçada. A realidade do trabalho ultrapassa ainda o plano puro do tempo abstrato e põe-se, no plano mental, como uma exigência ética da sociedade contemporânea. Dessa ideia, da forma como foi construída, podemos derivar o argumento do qual compartilha R. Kurz, ao afirmar que todos estão sujeitados ao que seria uma dominação sem ação de um sujeito, mas sim de uma lógica geral.

$\mathrm{Na}$ era burguesa, a história não parece uma luta conscientemente travada com a natureza e o desenvolvimento permanente de todas as suas faculdades e potencialidades, mas um destino sem sentido, perante o qual o indivíduo pode comportar-se com maior ou menor habilidade, de acordo 
com sua situação de classe. Na liberdade e aparente genialidade do empresário, cuja fama contribui para reforçar sua autoridade, esconde-se qual núcleo a assimilação a uma condição social na qual a humanidade não tomou em mãos o seu destino; a sujeição a um evento cego em vez de seu ordenamento racional; [...] em suma, nesta liberdade esconde-se uma renúncia à liberdade decerto originalmente necessária, mas hoje retrógrada, o reconhecimento do poder cego do acaso, uma autoridade há muito desacreditada. (1936:202)

A autoridade, que durante o liberalismo parecia ruir, na verdade apenas passava a se ocultar sob a linguagem dos fatos econômicos. É dessa forma que autor explica o aparecimento de nossa realidade atual como instância insuperável, aos nossos olhos, diante da qual nos sentimos não participantes, embora tenhamos a suposta liberdade de ação nessa sociedade. A liberdade é, na verdade, uma aparência necessária de nosso processo social, e só existe enquanto forma de consciência: "a liberdade defendida na filosofia é uma ideologia, ou seja, uma aparência necessária pela forma específica do processo social de vida" (1936:207). Não se pode conquistar a liberdade "aqui e agora" como um ato apenas de vontade, ignorando as condições materiais e sociais para tal.

A liberdade pode até mesmo ser vista, no limite do argumento dentro dessa linha, como funcional ao se tornar uma válvula de escape e permitir "uma ilusão da liberdade" que os mantenha ocupados com suas fantasias. Hakim Bey possui uma recusa pressuposta à essa formulação. Ele a fortalecerá com maiores argumentos a posteriori, como a teoria do caos, a cartografia cotidiana, os espaços digitais, mas ele não teme partir de uma negação "por princípios" ao pessimismo generalizante da "dominação sem sujeito" que paira sobre todos nós.

A TAZ é uma tática de ação, é a possibilidade de vivência da liberdade no presente, uma intensificação da vida, de aspectos contestatórios, mas também festivos e espontâneos. Parte de argumento parcialmente (ou quase totalmente dependendo da leitura feita) emocional sobre não aceitar o fim conceitual da liberdade. A TAZ é, acima de tudo, um ato consciente. Uma forma de agir por todas as brechas possíveis no suposto Sistema de Controle Universal de forma a criar zonas liberadas, sabidamente temporárias, permitindo um ataque às estruturas de controle, essencialmente às ideias. Seu grande trunfo está na sua mobilidade e sua invisibilidade, o que a torna perfeita para atuar eficazmente no mundo moderno. 
A TAZ é uma espécie de rebelião que não confronta o Estado diretamente, uma operação de guerrilha que libera uma área (de terra, de tempo, de imaginação) e se dissolve para se re-fazer em outro lugar e outro momento, antes que o Estado possa esmagá-la. Uma vez que o Estado se preocupa primordialmente com a Simulação, e não com a substância, a TAZ pode, em relativa paz e por um bom tempo, "ocupar" clandestinamente essas áreas e realizar seus propósitos festivos. (...) Assim sendo, a TAZ é uma tática perfeita para uma época em que o Estado é todo-poderoso mas, ao mesmo tempo, repleto de rachaduras e fendas. (BEY, 1990:14)

A razão principal desta abordagem seria evadir da violência do Estado, pois, para o autor, não é uma violência com sentido. "Todos os seus revolveres estão apontados para nós" (1990:15). O poder já perdeu seu sentido e tornou-se puro Espetáculo e a Simulação. A TAZ representa, portanto, o concreto e imediato, assim como a possibilidade e o devir. Não se trata, portanto, de ação indireta, como a princípio poderíamos concluir, mas de ação direta que contorne o confronto direto.

A TAZ emerge baseada em alguns elementos colocados pelo autor como suas inspirações "negativas" e suas inspirações positivas. Inicialmente, A TAZ surge de uma crítica à noção de revolução: segundo o autor as revoluções caracterizam-se na história como bem sucedidas quando conquistam permanência. Levantes e insurreições são as revoluções que fracassaram, foram manifestações temporárias. A permanência acaba por conformar sempre uma reação, um Estado mais opressor que o anterior e, portanto, não nos leva a parte alguma, como bem demonstrou o século XX. Os levantes sim, sempre que possíveis e até com risco de violência, pois estes carregam a essência da revolta, seus aspectos festivos. Definido pela história como fracasso, o levante aqui é visto como uma possibilidade de emancipação vista pelo autor como mais interessante “do que as 'bem-sucedidas' revoluções burguesas, comunistas, fascistas, etc.” (1990:16), já que ele não resulta em uma nova forma de opressão.

O fechamento do mapa seria a segunda inspiração negativa da TAZ, ao lado do fim da revolução. Em 1899 reivindicou-se o último pedaço de terra não reclamada por governo algum, de terra incógnita. Em teoria, elaborou-se um sistema de divisão espacial abarcando 
o mundo inteiro, uma malha política abstrata constitutiva dos territórios. O mapa, contudo, nunca é exato, "não pode ser exato" (1990:16).

O mapa está fechado, mas a zona autônoma está aberta. Metaforicamente, ela se desdobra por dentro das dimensões fractais invisíveis à cartografia do Controle. E aqui podemos apresentar o conceito de psicotopologia (e psicotopografia) como uma "ciência" alternativa àquela da pesquisa e criação de mapas e "imperialismo psíquico" do Estado. Apenas a psicotopografia é capaz de desenhar mapas da realidade em escala 1:1, porque apenas a mente humana tem a complexidade suficiente para modelar o real. Mas um mapa 1:1 não pode "controlar" seu território, porque é completamente idêntico a esse território. Ele pode ser usado apenas para sugerir ou, de certo modo, indicar através de gestos algumas características. Estamos à procura de "espaços" (geográficos, sociais, culturais, imaginários) com potencial de florescer como zonas autônomas - dos momentos em que estejam relativamente abertos, seja por negligência do Estado ou pelo fato de terem passado despercebidos pelos cartógrafos, ou por qualquer outra razão. A psicotopologia é a arte de submergir em busca de potenciais TAZs. (1990:14)

Esses espaços potenciais para o surgimento da TAZ precisam ser percebidos e utilizados. Para o autor, eles existem porque é impossível um sistema de controle absoluto em escala planetária. Ele utiliza argumentos da teoria do Caos como forma de pressupor a impossibilidade de um sistema de controle universal totalmente eficaz, dada a quantidade de variáveis. Na física, essa teoria ajudar a pensar sistemas instáveis como os buracos negros e a turbulência das aeronaves. O matemático Beinot Mandelbrot, um dos principais cientistas a estudar essa teoria, é responsável pela descoberta da maior formação fractal conhecida: o Mandelbrot Set, batizado em homenagem a seu idealizador. Ao longo de uma vida toda é impossível conhecer todos os terminais que compõem o M Set. Esses sistemas caóticos são aplicados pelo autor como forma de reconhecer a não exatidão de qualquer cartografia de controle universal. Tais argumentos são uma via totalmente diferente para a explicação de por que o círculo totalizante do capital não fecha, tão discutido por Lefebvre e Fabiana Valdoski Ribeiro. Aqui, vemos voltar ao ponto de destaque as fissuras e brechas tão citadas 
por esses dois autores, que na descrição de Hakim Bey possuem um papel de dar "vida" ao mapa 1:1 e gerar milhares de variáveis imprevisíveis:

\begin{abstract}
Abra um mapa do território; sobre ele, coloque um mapa das mudanças políticas; sobre ele, ponha um mapa da internet, especialmente da contranet, com sua ênfase no fluxo clandestino de informações e logística; e, por último, sobre tudo isso, o mapa 1:1 da imaginação criativa, estética, valores. A malha resultante ganha vida, animada por inesperados redemoinhos e explosões de energia, coagulações de luz, túneis secretos, surpresas. (1990:19)
\end{abstract}

Vemos assim ressaltar-se o aspecto espacial da TAZ. Embora possua também existência potencialmente virtual, ela ganha vida diante de um espaço permeado por uma conjunção infinita de forças. Essa visão assemelha-se ao descrito por Lefebvre ao tratar do espaço em perspectiva semelhante. Para Lefebvre (2006:13; cap. II):

Seja como for, os lugares não se justapõem somente no espaço social, em constraste com aqueles espaço-natureza. Eles se interpõem; se compõem, eles se superpõem e às vezes se chocam. $\mathrm{O}$ resultado é que o local (o "pontual", determinado por tal ou tal "ponto") não desaparece, absorvido pelo regional, pelo nacional, pelo próprio mundial. O nacional e o regional englobam muitos "lugares". O espaço nacional engloba regiões; o mundial não apenas envolve os espaços nacionais, mas provoca (até nova ordem) sua formação, num notável fracionamento. Múltiplos fluxos atravessam esses espaços. O espaço social começa a aparecer em sua hipercomplexidade: unidades individuais e particularidades, fixidades relativas, movimentos, fluxos e ondas, uns se compenetram, outros se afrontam etc.

A TAZ é utópica no sentido em que imagina uma intensificação da vida cotidiana e aponta um horizonte possível de superação das condições sociais vigentes. Contudo possui uma existência real no tempo e real no espaço. 
A TAZ existe em algum lugar. Ela fica na intersecção de muitas forças, como um ponto de poder pagão na junção das misteriosas linhas de realidade paralela (...). Talvez essas linhas possam ser melhor estudadas à luz da ciência do caos do que à luz da sociologia, estatística, economia, etc. (1990:21).

Além das fontes negativas, o que a TAZ não é, há também as fontes positivas, pois um levante é a favor de algo. Três pontos são levantados pelo autor: o bando, o festival e o nomadismo psíquico. O bando refere-se a um tipo de "antropologia natural" da TAZ: o esfacelamento cada vez maior da família nuclear fechada leva tendencialmente à organização em grupos de afinidades que a substituem, estes podendo ser comparados à organização paleolítica radical do bando. Oposto à família hierárquica, o bando é horizontal, é aberto (não para todos, claro) e estabelece um padrão de aliança entre os membros. A TAZ como festival ressalta seus aspectos festivos e espontâneos, pois o acontecimento é essencial para ela. O nomadismo psíquico, por fim, é vital para a mobilidade da TAZ, pois assumido como tática ele permite articular espaços e informação, ações à deriva. Esse nomadismo define, por exemplo, o perfil de alguns nômades revolucionários que, "perambulando de revolta em revolta" (1990:31), procuravam uma forma de sempre ocupar uma zona autônoma temporária.

A TAZ agora deve existir dentro de um mundo de espaço puro, o mundo dos sentidos. No limiar, mesmo num ponto de evanescência, a TAZ deve combinar informações e desejos para realizar sua aventura (seu "acontecimento"), para preencher-se até as bordas de seu destino, para intensificar-se com sua própria emergência. (...) Mas a TAZ não se preocupa muito com o "foi" ou o "será". A TAZ está interessada em resultados, ataques com êxito à realidade consensual, conquistas de patamares de vida mais altos e intensos. (1990:25). 
Hakim Bey parece concordar com Lefebvre quanto ao cotidiano e sua capacidade de conter as imanências do ser humano em sua espontaneidade, possuindo um potencial revolucionário. Para Bey é no cotidiano que se busca a luta contínua da revolução de todo dia, pois: "a luta que não pode cessar mesmo com o fracasso final da revolução política ou social, porque nada, exceto o fim do mundo, pode trazer fim para a vida cotidiana" (1990:35). Lefebvre aponta o cotidiano como o plano imediato no qual as contradições manifestam-se concretamente, sendo por isso o plano privilegiado de análise que revela os conteúdos da vida na modernidade. Portanto, Bey coloca sobre o cotidiano os gestos e ações que agem diretamente contra a realidade do consenso espetacular. "Esses gestos são feitos contra instituições, e nesse sentido são 'negativos' - mas cada gesto negativo também sugere uma tática 'positiva' para substituir, em vez de simplesmente refutar, a instituição desprezada" (1990:35). Dessa forma, o ato torna-se ativo e consciente ao invés de apenas apático. Poderíamos citar a título de exemplo:

A recusa do Trabalho pode tomar a forma de vadiagem, embriaguez em serviço, sabotagem e pura falta de atenção, mas também pode originar novos modos de rebelião: mais empregos de autônomos, maior participação da economia "informal" e lavoro nero, fraudes no sistema previdenciário e outras opções criminosas, cultivo de maconha etc. atividades mais ou menos invisíveis se comparadas com as táticas de confronto tradicionais da esquerda, tal como a greve geral. (1990:39).

A TAZ é, portanto, um momento e um espaço de liberdade não só possível como existente. Abre-se como uma possibilidade de libertação psicológica, para sabermos de fato as maneiras como somos reprimidos (e auto-reprimidos) e para que o cenário de autonomia se instale no presente e não apenas para as gerações futuras. Não se trata, dessa forma, de uma fuga para o passado ou para um limbo hipotético ou mesmo em um futuro longínquo.

Já que a TAZ existe agora, ela significa muito mais do que uma mundanalidade negativa ou um escapismo contracultural. Mencionamos o aspecto festivo do momento descontrolado, e que se concentra numa espontânea, ainda que breve, auto-organização. Ele é "epifânico": uma 
experiência de pico, tanto em nível social quanto individual. A liberação é percebida durante o esforço: essa é a essência da "auto-superação" nietzscheana. Essa tese pode também tomar como símbolo o andarilho de Nietzsche. Ele é o precursor do vagar a esmo, no sentido dado pelo situacionismo para dérive e da definição de Lyotard para driftwork. Podemos antever uma geografia completamente nova, um tipo de mapa de peregrinação no qual os lugares sagrados são substituídos por experiências de pico e TAZ: uma ciência real de psicotopografia, para ser chamada talvez de "geo-autonomia" ou "anarcomancia". (1990:39).

Diante do exposto, fica evidente o conflito latente entre a liberdade possível (e em algum sentido até existente) proposta pela TAZ e o sentido fechado da liberdade como forma de consciência proposta pela Teoria Crítica. Quanto ao que se entende por Teoria Crítica nesse trabalho, cabe aqui uma ressalva: nosso conhecimento acerca dessa teoria vem por alguns meios que convém ser explicitados: primeiramente, por meio de professores do Departamento de Geografia da FFLCH/USP (como Anselmo Alfredo e Carlos A. Toledo) que defendem essa abordagem em suas aulas, assim como por colegas da graduação e pósgraduação que compartilham dessas ideias e frequentam grupos de estudos com esses professores (incluindo a mim). $\mathrm{O}$ contato mais profundo foi na disciplina de graduação “Teoria Crítica”, com Ricardo Musse, do departamento de Ciência Política da FFLCH/USP, através do qual nos foram apresentados os autores e textos que compõem parte do arcabouço teórico dessa linha, como, por exemplo, Horkheimer (1936), Adorno e Horkheimer (1985). $\mathrm{Na}$ Geografia da USP, essa linha ganha mais corpo principalmente com as leituras do grupo krisis e, principalmente, de Robert Kurz (2003; 2000), já citado anteriormente.

Não consultamos nenhum autor ou autora em especial que tratasse das ocupações ou resistências pela perspectiva da Teoria Crítica. Nossa interpretação dos argumentos essenciais dessa teoria advém de um conhecimento sobre essa linha de investigação em seu funcionamento lógico geral. A partir disso, derivamos a interpretação dela para o fenômeno das ocupações. Um exemplo mais claro: considerando o argumento de Robert Kurz (2000) acerca do sujeito sujeitado, é impossível conceber que sua interpretação acerca das ocupações possa vir a resultar em algo que supere o capital (ou aponte um sentido de superação), ou mesmo algo que possa a ser encarado como um movimento de resistência à urbanização, na medida em que esses movimentos seriam vistos como parte integrante 
fundamental da lógica geral de reprodução capitalista, ainda que em sua forma negativa. Isso molda toda uma série de argumentos acerca do papel de uma ocupação por moradia ou mesmo por reforma agrária ${ }^{17}$. Portanto, nossa leitura sobre os argumentos da Teoria Crítica é baseada em nossa interpretação da lógica geral em torno da qual gira a crítica fundamental dessa linha. Nossa escolha em dialogar com ela reside no fato de que, embora ela seja praticamente incapaz de realizar propostas, essa linha possui questionamentos e críticas sempre muito interessantes às outras abordagens de forma que é sempre muito profícuo com ela debater.

Seu argumento principal sobre a ocupação fundamenta-se em dois pontos essenciais: primeiro, uma vez que ela represente o negativo do capital, a resistência está dialeticamente contida no processo e se define em função desse capital. Além disso, ela seria um produto lógico das relações capitalistas repondo, em potência, os pressupostos do capitalismo, o que nos leva ao segundo ponto: a ocupação (e o movimento por moradia em geral) reivindica e deseja de certa forma o acesso à propriedade privada, para tal estabelece uma relação com o Estado, etc. Isso seria uma maneira de reposição dos fundamentos sociais do capital (como propriedade e Estado) por meio da atuação do movimento, o que o colocaria como mais um dos aspectos do capital, mesmo que em sua forma negativa. Portanto, não é possível, para a Teoria Crítica, a superação das contradições do capital por meio da ação de um movimento social porque esta superação pressupõe a reposição de suas próprias categorias. São as categorias do capital que constituem as contradições que se desejam superar, o que geraria uma contradição no próprio argumento. É importante enxergar que o limite da crítica está posto, para eles, na incapacidade da consciência de propor outras categorias que não as de um indivíduo socializado pelo valor e pela abstração. Essa consciência sendo uma objetividade, criticá-la não significa superá-la, mas por em questão a forma de consciência. Essa superação, caso seja possível, não viria certamente por essa via.

Uma forma possível de tencionar a ideia da insurgência da resistência é confrontá-la (em sua forma potencial ou não) com a perspectiva da Teoria Crítica quanto a maneiras de transformação da nossa realidade. Uma questão nesse sentido, ainda aberta, é de até que ponto a incapacidade de propor o novo, para além do capital, como afirma a Teoria Crítica, é excludente da ideia de transformação social possível. Em muitos momentos da história

\footnotetext{
${ }^{17}$ Um argumento teórico possível a partir dessa linha de pensamento, por exemplo, é qualificar movimentos de moradia ou de reforma agrária como partes integrantes e reprodutoras do capitalismo, uma vez que reivindicam a propriedade privada. Embora não se negue aqui que essa contradição está posta para os movimentos sociais, isso não significa, a nosso ver, que tais movimentos são apenas instâncias reprodutoras da ideologia capitalista.
} 
houve rupturas significativas em mentes que operavam por conceitos distintos da socialização pelo valor, no entanto essa forma de consciência se efetivou como generalidade. Embora a formulação de novas categorias não seja possível, e estendendo aqui o limite do argumento, até que ponto as transformações sociais futuras não estão gestadas nas lutas do presente? A ideia do virtual, presente em Lefebvre, nos permite pensar o utópico. A Teoria Crítica nega tal possibilidade, mas não pode deixar de perceber que categorias totalmente novas surgiram em meios nos quais nenhuma referência anterior às permitia explicitar, e hoje se põem como generalidade. Qual exatamente será a via que permitirá categorias para além do capital, estas totalmente hipotéticas, em uma sociedade pós-capitalista? Ou seria o capitalismo de fato o fim da história e sua realidade autorreferente nunca poderá ser rompida?

Essa dialética entre um mundo aberto e um mundo fechado pode ser melhor pensada a partir da TAZ, pois ela aponta a possibilidade de uma totalidade aberta na qual a realidade em movimento segue em direção ao sentido do possível.

\section{4. - TAZ, Momentos e Situações}

A leitura da TAZ permite vincular suas experiências de pico com noções semelhantes como a teoria dos momentos de Lefebvre (1958, 1961), com o cotidiano de potencial revolucionário, ou ainda a de situação, dos situacionistas (Debord, 1958, 13). As situações tem seu aspecto circunstancial ressaltado, bem como o efêmero da intensificação de vida da situação, flashes de vida em "nível superior de qualidade passional”.

Situação construída: momento da vida, concretamente e deliberadamente construído pela organização coletiva de uma ambiência unitária e de um jogo de acontecimentos.

Situacionista: aquele que se relaciona à teoria ou à atividade prática de uma construção de situações. Aquele que se dedica a construir situações. Membro da Internacional Situacionista.

Em Lefebvre vemos a possibilidade de uma práxis que supere o cotidiano, ser o seu outro sem cessar sua relação dialética com a totalidade; é o seu outro e está encerrado nele ao mesmo tempo em que aponta para algo que está além e não está definido em função de 
seus limites negativos. No conceito de momento reside o conteúdo do vivido como um lapso de tempo privilegiado que valoriza justamente o seu aspecto descontínuo e espontâneo, aproximando-o da ideia de TAZ.

As três ideias carregam em si a possibilidade de transformação no horizonte; o adjetivo de paixão com carga até mesmo, no limite, emocional; o tornar possível o impossível-virtual. Destaca-se o potencial criador que permite ler a ação enquanto obra, em uma manifestação do espontâneo humano de cunho transformador. É o mesmo sentido dado por Lefebvre ao uso ou ao espaço como obra.

O fundamento desse espontâneo é a ideia de que o mundo da mercadoria não totalizou todas as relações sociais do mundo. Apontamos a concordância com a ideia de que o mundo da mercadoria não é a explicação para absolutamente tudo no mundo atual, ainda que muito do que está fora de seus limites se defina em função de ser o seu negativo, e como seu outro está dialeticamente vinculado ao seu universo. Trata-se do longo debate acerca de quão totalizante é o mundo da mercadoria. Como vimos, há brechas no cotidiano, e a ideia da TAZ é bastante potente para apontar uma infinidade de brechas. A posição aqui é clara: não houve a totalização, ainda que apenas alguns aspectos humanos estejam fora do alcance dessa socialização pelo valor. É difícil ser taxativo ou classificatório quanto ao "dentro" e "fora", mas muitas questões interessantes e de longa discussão poderiam se levantadas: seria o amor explicado pelo mundo da mercadoria? A fé? A vivência intensificada de uma ocupação? Em que medida sim e em que medida não? Longe de esgotar essas questões, nosso simples encaminhamento neste trabalho é a leitura questionadora dessa totalização do mundo da mercadoria.

Propomos ler, a partir dos movimentos de resistência à urbanização, essa espontaneidade que pode apontar para esse irredutível humano (nos termos de Lefebvre), de potência transformadora, como não definida de forma interna ao mundo da mercadoria, mesmo que de forma pontual e ainda limitada à questão da habitação. Ressaltamos que o ainda não cooptado não é visto aqui como aquilo que ainda será, numa perspectiva temporal. Nesse pensamento, a visão do mundo da mercadoria soa como uma mancha de óleo que não se espalhou totalmente por uma superfície plana, e os pontos sem óleo são os lugares "ainda sem mácula". O irredutível também pode apontar o novo, a superação do que está, uma virtualidade. Algo que não se defina necessariamente em função do presente, tão pouco algo que sempre esteve presente "em essência" conosco por toda a história. Mas, sim, algo novo.

Nossa discussão tangencia o mundo da mercadoria em outro sentido: o que Hakim Bey leu como "brechas" no sistema-mundo não são as rachaduras ainda não ocupadas, ou o 
óleo ainda não espalhado, mas produto contraditório da própria lógica de produção do homogêneo e que aponta para uma superação que foge ao escopo do mundo da mercadoria, ainda que de forma virtual. Na tentativa de igualar, produz-se inerentemente o espaço da diferença como forma de contestação. Mesmo que não seja uma contestação de fundo revolucionário, como no caso da TAZ, e ainda que não seja o objetivo uma revolução total e irrestrita (mas apenas um levante, conforme discutido por Hakim Bey), isso não torna essas contestações menos importantes. Esse espaço da diferença é que possibilita o surgimento da TAZ, possibilita virem à tona o uso e a obra, o momento, a situação, o irredutível humano não definido pelo mundo da mercadoria e nem pelo seu negativo dialético. Todos eles, na leitura lefebvriana, são latentes no cotidiano e podem, potencialmente, ser uma força transformadora. O pensamento dialético operando por meio do possível-impossível, do realvirtual, nos coloca, aliás, que os elementos para superação da nossa realidade estão gestados no presente. Não significa buscar uma relação causal e mecânica, mas antes uma gênese lógica que fundam as possibilidades de transgressão e resistência.

Trazemos para a discussão a TAZ porque ela permite ler de outro modo as ocupações urbanas, apesar de uma série de limites em sua abrangência. Contudo, sua aberta definição polissêmica permite uma aplicação que, tendo no horizonte o objetivo de tencionar as possibilidades sem delas fazer um dogma, nos levará a uma nova geografia da TAZ. Não se trata de cartografar a TAZ, ou classificar qual fenômeno se encaixa ou não na definição prévia, mas de compreender sua potência de leitura do momento atual - da ação por meio do espaço - , de tática possível de transformação da realidade por parte dos movimentos sociais contemporâneos, e de crítica possível aos modelos tradicionais de luta e até do pensamento teórico ante as mobilizações. A TAZ indica não só o seu papel como virtualidade, mas também como atuação na transformação presente, como liberdade ou intensificação de vida possível e atual, no nosso tempo e não apenas no futuro.

A TAZ, o momento e a situação, portanto, parecem convergir para a explicação de uma via possível e existente de transgressão e resistência. Isso não significa um processo isento de contradições, ou mesmo que se encaixe perfeitamente ao mundo teórico, mas talvez indique uma luz no fim do túnel diante da realidade totalmente dominada pela mercadoria e seu mundo sem possibilidade de fuga ou transformação. 


\section{CONSIDERAÇÕES FINAIS}

Nossa visão compreende esse processo de urbanização (em especial na sua face mais violenta) como estando em disputa pelas várias forças, agentes e processos dos quais pretendíamos realizar um exame crítico, para tentar responder nossas questões acerca do conteúdo dos movimentos de resistência à urbanização. Destacamos que parte desse debate está aqui esboçado, mas estas questões ainda não estão fechadas e nem pretendemos esgotálas. Todavia, nossas considerações finais almejam encaminhar de forma mais definitiva tantas questões quanto nos forem possíveis dentro de nossa proposta. Para tanto, vamos aqui retomar os principais pontos discutidos e, à luz de todo debate empreendido, finalizar nosso trabalho tentando observá-lo por uma perspectiva ampla.

Considerando que a vida cotidiana se compõe de momentos, o que do ponto de vista da geografia aparece também como espaços-tempos, o que a pesquisa de campo de campo nos levou a concluir é que esse cotidiano recortado nos leva a uma cidade vivida como privação, o que aparece do ponto de vista da morfologia como segregação. A segregação pode ser entendida como um dos produtos principais da reprodução do espaço urbano na contemporaneidade.

Seria a ocupação no centro, realizada pelos moradores da comunidade removida, uma forma de resistência à lógica do processo de reprodução do espaço urbano neste século XXI? Em que termos? Ou, considerando que a principal reivindicação dos cidadãos é a moradia em sua forma de propriedade privada, seriam eles meros reprodutores da lógica do capital? No fim das contas, é o que eles buscam? Quais os caminhos para se pensar isso?

Vemos a ocupação como um movimento de resistência à urbanização. Enquanto resistência, propõe um projeto político de (re)apropriação da cidade. No bairro novo, essa resistência tomou a forma de transgressões distintas, mas nem por isso destituídas de conteúdo. Embora sejam produto da opressão, de um movimento de intervenção estatal no espaço, as resistências apontam a possibilidade de conteúdos distintos para além de apenas reivindicar uma propriedade e, nessa medida, repor mais uma lógica de realização da cidade capitalista. A busca da casa em sua forma propriedade é, evidentemente, uma das tantas contradições vividas pelos movimentos de resistência à urbanização. Observamos que esses momentos, essa intensificação provocada pela TAZ, pela transgressão, não revela conteúdos apenas relativos ao mundo da mercadoria ou ao seu negativo imediato, mas aponta outra possibilidade, um terceiro termo. É evidente que a TAZ é uma utopia radical e que, nesse 
sentido, aponta um sentido possível. Não se trata, portanto, de classificar quais movimento são ou não uma TAZ, ou de coloca-la como a fórmula mágica de superação das contradições da cidade capitalista, mas de apontar um sentido que dialetiza a totalização do mundo pelo capital.

A TAZ aponta a possibilidade das brechas nesse mundo da mercadoria, visto pela Teoria Crítica como algo totalizante. Porém essas brechas não são por nós encaradas como característica inerente do capitalismo, mas sim como produto das resistências. Propomos um caminho de reflexão para pensar isso no sentido dialético de que as brechas possibilitam a resistência e a resistência possibilita a existência das brechas. A TAZ permite pensar uma totalidade aberta, pensar na realidade que se move em uma direção. Em que direção ela se move? Trata-se aqui de pensar uma dialética dessa abertura e fechamento na qual pensemos as brechas como a implosão de qualquer possibilidade de totalidade fechada.

No caso analisado, a resistência não acabou com a ocupação. A prática espacial e a consciência do processo para os envolvidos no processo jamais será a mesma. É claro que o grau de transformação é diferente para os que participaram da ocupação e os que foram para o bairro novo. Contudo, cada grupo engendrou sua própria forma de transgredir e trilhar suas estratégias de sobrevivência em uma cidade vivida por eles como privação.

A identidade vazia (o que também é uma forma de identidade) no novo bairro contrasta fortemente com o sentimento de união que imperou na ocupação e aglutinou lutas. Esse sentimento de unidade foi carregado para a casa conquistada e já se traduz em práticas espaciais capazes de transformar o lugar onde vivem. Seria essa identidade uma forma de apropriação? De certa forma, podemos afirmar que a apropriação passa pela identidade constituída através do uso do espaço.

Nossa análise perpassou brevemente a discussão sobre o Estado. Vemos que o Estado é o sujeito fundamental na produção do espaço por várias razões: domínio territorial, monopólio da violência, domínio político, exerce o poder em nome do capital. Relativizamos essa ideia do Estado como cumpridor de interesses da burguesia com base na discussão que questionava se a lógica capitalista da esfera estatal vinha do fato do Estado ser capturado por uma classe. $\mathrm{Na}$ verdade, é parte de sua lógica de reposição enquanto Estado realizar essa lógica. Vimos também que, apesar da presença esmagadora do Estado na sociedade, existem fissuras, sistemas caóticos, lógicas e contra lógicas que às vezes se unem e às vezes se chocam, mas que, no nosso entender, enriquecem a discussão sem apagar algumas lógicas fundamentais sem as quais o Estado não se repõe enquanto tal, como, por exemplo, a lógica 
da propriedade privada da terra. Intentamos também que seu domínio total fosse relativizado pela TAZ. Isso nos introduzi questões: em que medida faz sentido hoje uma luta por um Estado provedor de direitos? Em que medida o Estado ainda pode ser o interlocutor da manutenção de direitos?

Entendemos que essas questões estão longe de serem esgotadas e essa não é a pretensão aqui. Apenas almejamos movimentar categorias que lançam alguma luz ao debate sobre a crise da reprodução das relações sociais na sociedade capitalista, pois, segundo Lefebvre, estaríamos vivendo a passagem do momento da produção para o da reprodução. Esse é um dos vários movimentos de passagem realizados pelo autor para explicar as transformações da sociedade contemporânea. Nesse novo momento, a reposição dos pressupostos sociais capitalistas seria extremamente crítica. No momento de passagem para a reprodução, vemos o surgimento de novas formas de reposição da exploração sem que essa contradição fundamental seja superada ou resolvida.

Nesse movimento o espaço ganha centralidade, em especial o espaço urbano, tanto enquanto força produtiva para o capital quanto em suas várias outras dimensões: estratégia política tanto do Estado como dos movimentos sociais, objeto de disputas constantes na cidade capitalista. O espaço é o local do uso e da apropriação, mas também o local do interdito, da norma e da dominação. É ele o plano de realização e reprodução das relações sócio-espaciais, no qual as relações sociais ganham concretude (CARLOS, 2008). Por isso, as lutas na cidade contemporânea giram em torno do espaço.

As novas formas de opressão decorrentes suscitam inevitavelmente novas contradições que, potencialmente, nos trazem à tona formas diversas de resistência, o que aponta para nossa questão central: qual o papel dessas lutas e resistências diante do aumento da exploração? Como situá-las no debate da reprodução da sociedade? Como a resistência se insere no processo como um todo? Esperamos ter contribuído para o acúmulo de discussão que trará a resposta a essas indagações no curso de nosso trabalho. 
ANEXOS 
Emanull derafía oposición y atraye habitante de chabola con orsia

\section{Emanuel desafia oposição e atrai favelado com obra}

Projeto de desfavelização oférece escola, crechee unidade de saúde; PT promete reagir Prayecto du "dusfarelizacao ofrecu escuela, guardería in unidad ar pain a, PT promete rlacciemar.

$$
\text { DATA: } \underline{\cos 10+101}
$$

Prefeitura de São José A preparou um pacote Hor ciant par ver a cia dos moradores de favelas que se recusam a mudar para conjuntos populares na perife ria da cidade Oprojeto de des favelização envolve a construcão de 453 casas no Jardim Săo

Josée var oferecer escoln theche uinidade desaider che,

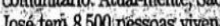
José tem 8.500 pessoas viven do em favelas. OPT, principal adversário do prefeito EmanuelFernandes (PSDB), defenMORADIA

de a reurbanização dos locais. Página 5

Anexo 1 - Promessas de trabalho e serviços para tentar atrair mais adesões para o projeto. 


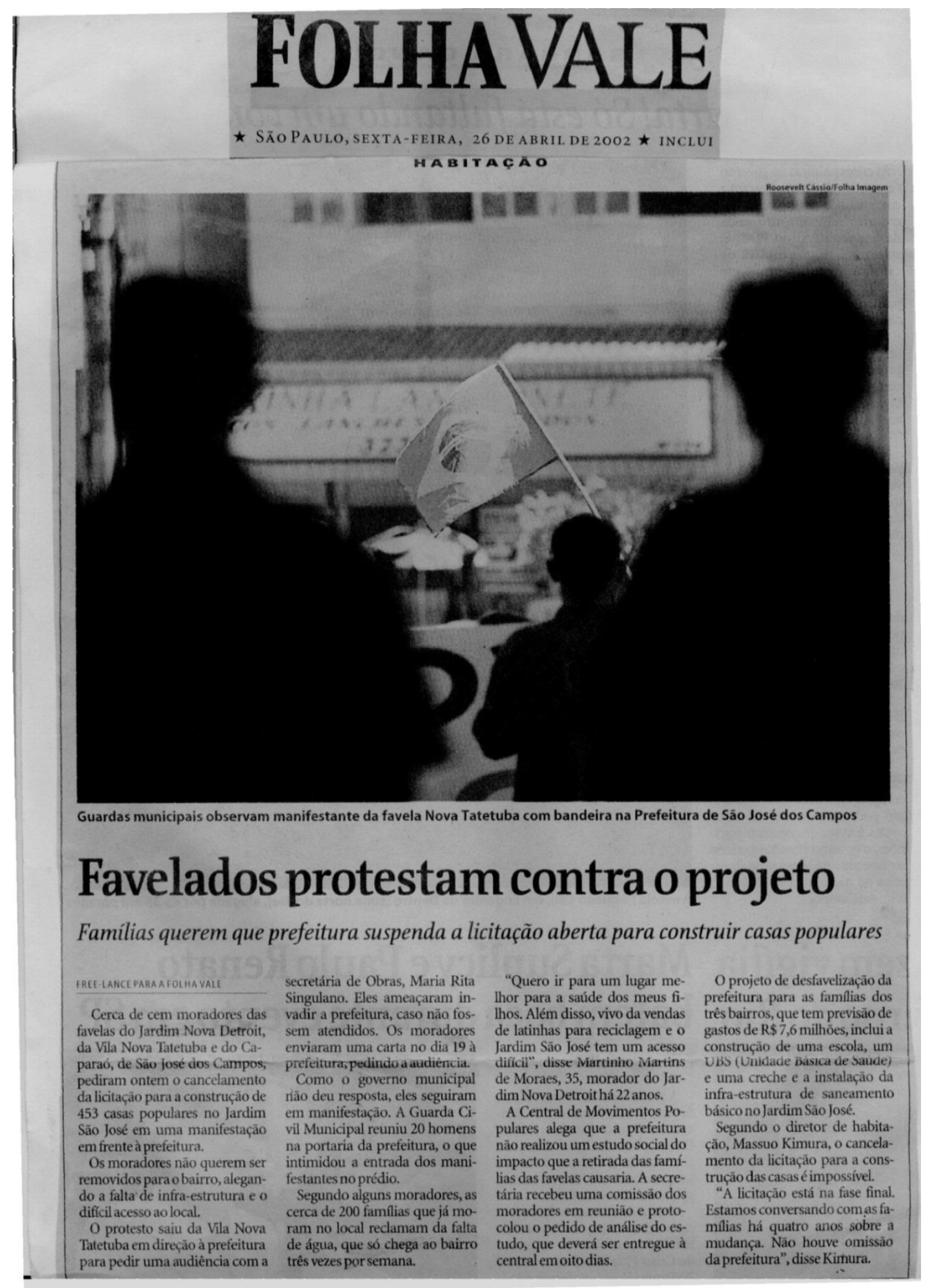

Anexo 2 - Resistência dos moradores ao projeto. 


\section{Emanuel vai ao bispo buscar apoio para a desfavelização}

Prefeito de São José apela à Igreja e entidades para garantir construção de 453 casas

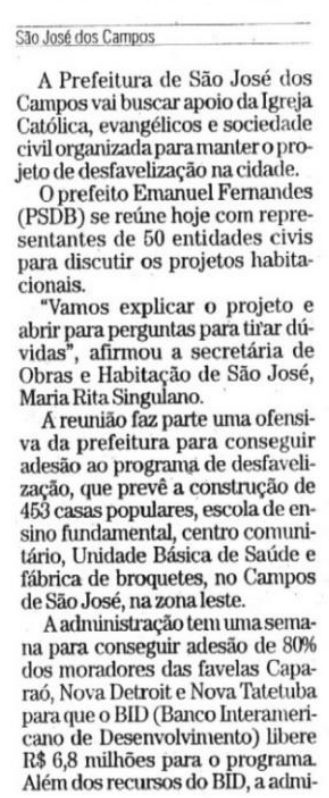

Além dos recursos do $\mathrm{BID}$, a almi-

\author{
nistração irá investir R\$1,7 millhão. \\ Na última segunda-feira a admi- \\ nistração distribuiu uma carta nas \\ três favelas convocando os mora- \\ dores para fazer o recadastramen- \\ o ao programa até o próximo sá- \\ bado. \\ "Comotêm váriosşegmentosna \\ Igreja, ficamos preocupados en \\ esquecer algum. Vamos marcar \\ un encontro com o bispo (don \\ Nelson Westrupp) para levar uma \\ cópia do projeto e explicá-lo. Com \\ igreja evangélica vamos fazer a \\ mesma coisa. Vamos fazer uma \\ apresentação específica para os \\ vereadores", disse Maria Rita. \\ Opadre Geraldo Magela dapas- \\ oral sócio-política de São José, \\ conhecimento do reuniăo entre \\ administração e diocese e nem do \\ projeto de desfavelização. \\ OPOSIÇÃO-Parapresidente doCMP \\ (Central de Movimentos Popula- \\ res), Cosme Vitor, a prefeitura de- \\ Favela Nova Detroit \\ que está no projeto \\ de desfavelização
com dinheiro do BID
}

\section{Entidades \\ desconhecem projeto} şo José dos Camoos

Entidades civis de Săo Jos afirmam que consideram impor tante a implantaçao do prograpio, mas dizem que nảo não conhecerem o projeto,
"A sociedade civil deveria par ticipar mais. A prefeitura est mulo lechada. Lla deveriaenvo vermaisnoprogramade destave lização as entidades que sao pa ceiras daptefeituranánea de de senvoline opresidente daAelo (Assoctaça das

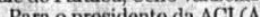
Para opresidente da ACr (Asde Sâo José Paulo Saes, o pro grama de desfavelização é in

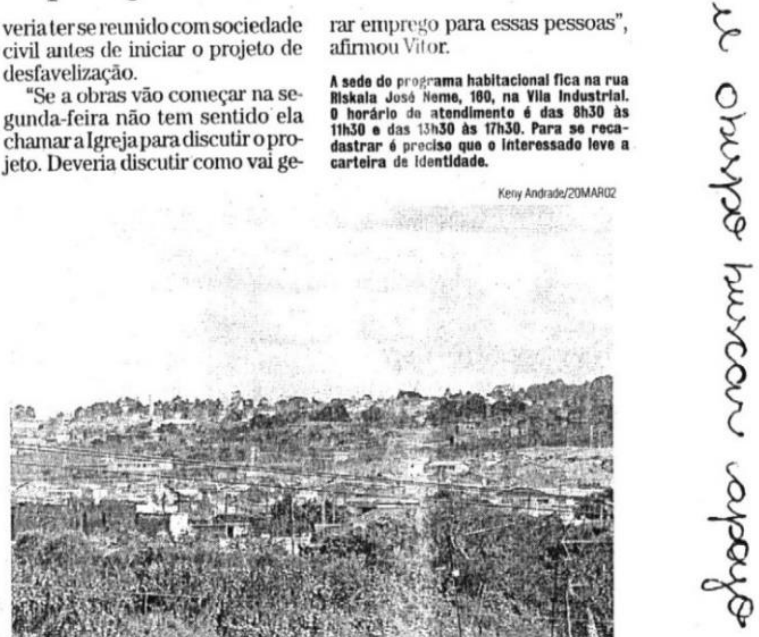

\%
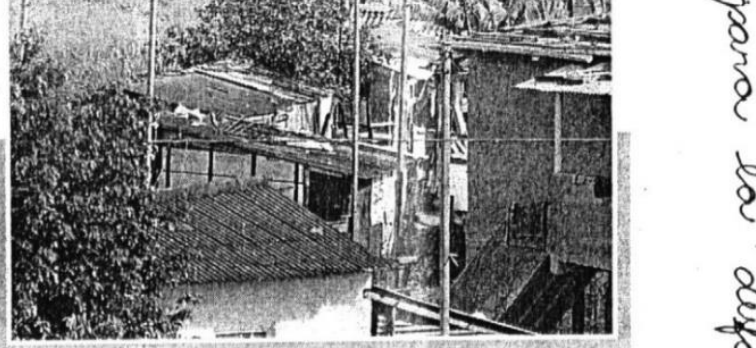

portante para melhorar a quali- moradores", disse Saes.

dade de vida da populaçấo. A reunião está marcada para

"Apoiamos a medida e vamos as $11 \mathrm{~h}$ no Paço Municipal. Fo-

à reunião. São José precisa con- ram convidadas entidades liga-

tinuar se desenvolvendo e dan- das a vários setores, mas prínci-

do condições melhores para os palmente à habitaçẩo

Entedades desconocen prafecto

\section{ValeParaibano}

Vale do Paraíba, quinta-feira, 23 de maio de 2002

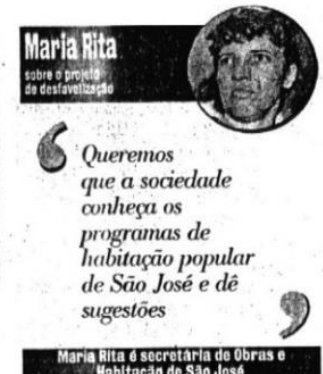

Anexo 3 - Tentativa de ampliar o número de adesões ao programa. 


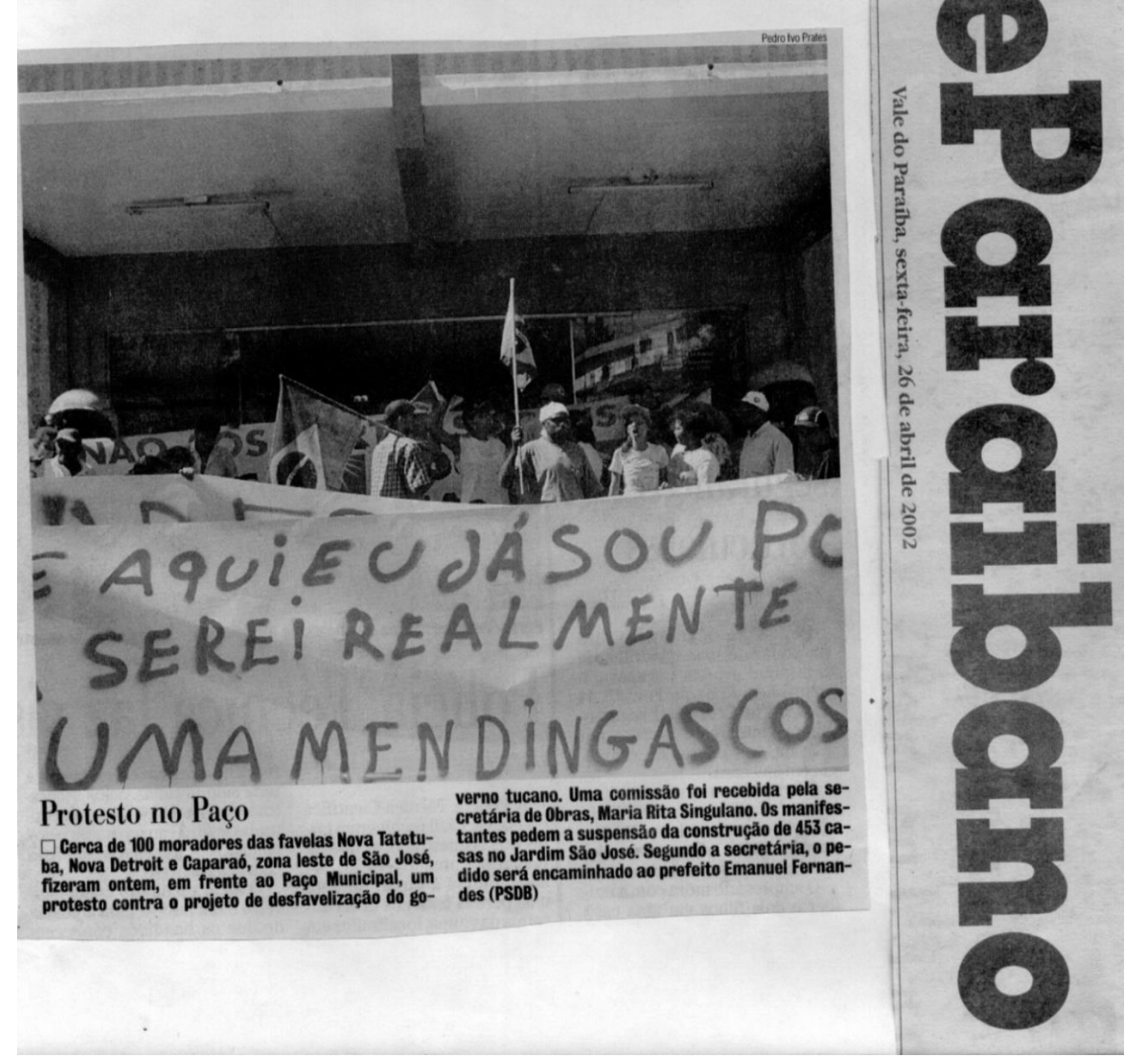

Anexo 4 - Protesto no Paço Municipal. 


\section{ValeParaibano}

Acadio cria estrategia para contener las 'ressitentes'

\section{Desfavelização}

\section{Prefeitura cria estratégia para conter os 'resistentes'}

Moradores das favelas Caparaó e Nova Tatetuba serão transferidos no sábado

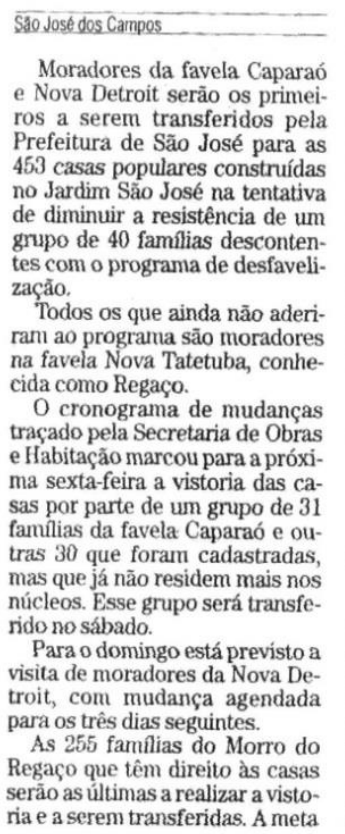

$\begin{array}{cc}\begin{array}{c}\text { é que toda a mudança esteja con- } \\ \text { cluída até o próximo dia } 21 .\end{array} & \begin{array}{c}\text { cão de uma escola e de uma cre- } \\ \text { che -inclúdas no pacote de R\$ }\end{array} \\ \text { "Nessa visita, as famnlias vão } & 9,25 \text { milhōes do programa finan- } \\ \text { conhecer o acabamento final da } & \text { ciado pelo BID (Banco Interame- } \\ \text { casa e também conhecer a UBS } & \text { ricano de Desenvolvimento)- } \\ \text { (Unidade Básica de Saúde) cons-- } & \text { só será finalizada em fevereiro. } \\ \text { trúda no bairro", disse a secretá- } & \\ \text { ria de Habitação, Maria Rita Sin- } & \text { ForÇA-TAREFA - A prefeitura tam- } \\ \text { gulano. } & \text { bém vem realizando um mutirão } \\ \text { A prefeitura encerrou na se- } & \text { para apressar a entrega das casas } \\ \text { gunda-feira o prazo para adesão } & \text { antes do Natal. A força-tarefa in- } \\ \text { dos moradores da Nova Tatetu- } & \text { clui a contratação de novos fun- } \\ \text { ba, mas ainda admite aceitar a in-- } & \text { cionários pela construtora Mas- } \\ \text { clusão dos descontentes até o dia } & \text { safera, responsável pela obra. } \\ \text { da mudança. } & \text { Ontem, Maria Rita passou } \\ \text { Segundo Maria Rita, a constru- } & \text { parte da manhã vistoriando as }\end{array}$

obras e admite a pressão, que ela entende ser normal dentro de um contrato.

Ontem, nove operários "cruza ram os braços" em protesto às condicões de trabalho oferecidas. De acordo como oferecicomaria que com, valor pago por dia é muito baixo. "Nẫo tem condição. Vou ga nhar $\mathrm{R} \$ 15$ por dia e tenho que pegar dols onibus e pagar o al moço. Vamos embora e não vamos voltar, disse $o$ ajudante de pedreiro Éder Moraes da Silva, 20 anos.

\section{Vereadores inspecionam as obras}

\section{São José dos Camoos}

Depois de uma vistoria realizada nas casas populares que estão sendo construídas no Jardim São José, na região leste da cidade,
vereadores do PT decidiram pedir a prorrogaçăo do prazo para a dir a prorrogaçáo do prazo

$\mathrm{Na}$ avaliação dos oposicionistas ao governo tucano, a mudança só deveria ser feita depois da conclusão de uma creche e de uma escola, incorporadas à obra das unidades habitacionais.

A Secretaria de Obras e Habia ão São do obras podem ser finalizadas em fevereiro, antes do início do ano letivo.

A vereadora Maria Izélia, líder do P'T na Câmara, também criticou o tamanho das casas construídas no Jardim São José, que possuem cerca de 40 metros quadrados.

"Uma familia de cinco pessoas nãotem condicões decolocarnem duas camas Na frente das cem não foi feito contrapiso. Hoje (ontem) tivetro para tisar no barro para entrar", afirmou a vereadora. Alêm de lzélia, também inspecionaram ontem as obras os vereadores Mauro Kano e Amélia Naomi.

$$
\text { concejales inspecionan las obras }
$$

Anexo 5 - Os moradores do Morro do Regaço se recusam a aderir. Prefeitura faz nova ofensiva. 


\section{REFERÊNCIAS BIBLIOGRÁFICAS}

ADORNO T.; HORKHEIMER, M. Dialética do esclarecimento. Rio de Janeiro; Jorge Zahar, 1985.

BEY, Hakim. Zona autônoma temporária. 1985. Disponível gratuitamente em: http://pt.scribd.com/doc/6603798/Taz

BRASIL, J.M.R.L. Estudo da vida cotidiana na periferia de São José dos Campos, SP Jardim São José II: um estudo de caso. 2013. Trabalho de Graduação Individual Faculdade de Filosofia, Letras e Ciências Humanas, Universidade de São Paulo, São Paulo, 2013.

CARLOS, Ana Fani A. Espaço-tempo na metrópole. São Paulo: Contexto, 2001. . Dinâmicas urbanas na metrópole de São Paulo. In: ARROYO, M.; SILVEIRA, M.; LEMOS, A. América Latina: cidade, campo e turismo. São Paulo: Clacso, 2006.

A (re)produção do espaço urbano. São Paulo: Edusp, 2008.

A “ilusão" da transparência do espaço e a "fé cega" no planejamento urbano: os desafios de uma geografia urbana crítica. In: Revista Cidades, vol. $6, \mathrm{n}^{\mathrm{o}} 10,2009$.

A condição espacial. São Paulo: Contexto, 2011. 
. Da "organização" à "produção" do espaço no movimento do pensamento geográfico. In: CARLOS, A. F. A; SOUZA, M. L.; SPOSITO, M. E. B. (org.) A produção do espaço urbano: agentes e processos, escalas e desafios. São Paulo: Contexto, 2012.

Metageografia: ato de conhecer a partir da Geografia. In: CARLOS, Ana Fani A. (org.). Crise urbana. São Paulo: Contexto, 2015.

. A privação do urbano e o direito à cidade em Henri Lefebvre. In:

CARLOS, Ana Fani A.; ALVEZ, Glória; PADUA, Rafael F. (orgs.). Justiça espacial e o direito à cidade. São Paulo: Contexto, 2017.

COSTA, Sandra Maria F.; FORLIN, Luiz Gustavo. Urbanização e segregação sócioespacial na cidade de São José dos Campos: o caso do Pinheirinho. Florianópolis, Geosul, vol. 25, nº 49, 2010.

DAMIANI, Amélia Luisa. A cidade (des)ordenada. In: Boletim Paulista de Geografia, $\mathrm{n}^{\mathbf{0}}$ $72,1994$.

DEBORD, Guy. Internationale situationniste. Revue Internationale Situationniste \#1. Paris, 1958.

HARVEY, David. O enigma do capital e as crises do capitalismo. São Paulo: Boitempo, 2011.

. A condição pós-moderna. São Paulo: Loyola, 17 edição, 2008. 
HORKHEIMER, A. Autoridade e família. Teoria Crítica, p. 175 - 236, Paris, 1936.

KOWARICK, Lúcio. A espoliação urbana. Rio de Janeiro: Paz e Terra, 1979.

. Viver em risco: sobre a vulnerabilidade socioeconômica e civil.

São Paulo: Editora 34, 2009.

KURZ, Robert. Dominação sem sujeito. In: Seminário internacional: A teoria crítica radical, superação do capitalismo e a emancipação humana. Fortaleza, Ceará, 29/10/2000. Disponível em www.obeco-online.org/.

Ontologia negativa. Disponível em: www.obecoonline.org/rkurz115.htm; acessado em 15/12/2016. 2003.

LEFEBVRE, Henri. La vie philosophique - chapitre I : Moments. In : La Somme et le Reste, Paris, 1958.

. Critique de la vie quotidienne II, Fondements d'une sociologie de la quotidienneté, Paris, L'Arche, 1961.

A revolução urbana. Belo Horizonte: Editora UFMG, 1999.

O direito a cidade. São Paulo: Centauro, 2001.

A produção do espaço. Núcleo de Geografia urbana da UFMG. Belo Horizonte, 2006. 
. Espaço e política. Belo Horizonte, Editora UFMG, 2008.

MARICATO, Ermínia. Para entender a crise urbana. São Paulo, Expressão Popular, 2015.

MARQUES, Eduardo. Elementos conceituais da segregação urbana e da ação do Estado. In: MARQUES, E. e TORRES H. (org.). São Paulo: segregação, pobreza e desigualdade social. São Paulo, Ed. Senac, 2005.

MARQUES, Eduardo. SARAIVA, Camila; Favelas e periferias nos anos 2000. In: MARQUES, E. KOWARICK, L. (org.) São Paulo: novos percursos e atores. São Paulo, editora 34, 2011.

MARTINS, José de Souza. Exclusão social e a nova desigualdade. São Paulo: Paulus, 1997.

PADUA, Rafael Faleiros. Espaços de desindustrialização na urbanização contemporânea da metrópole. In: CARLOS, Ana Fani A. (org.). Crise urbana. São Paulo: Contexto, 2015.

RESCHILIAN, Paulo Romano. A produção de assentamentos precários em São José dos Campos: a favela Nova Tatetuba, um exemplo para análise. Tese de doutorado, FAU/USP, 2004.

RIBEIRO, Fabiana Valdoski. A produção do lugar na periferia da metrópole paulistana. Dissertação de mestrado, FFLCH/USP, 2007.

A luta pelo espaço: da segurança da posse à política de regularização fundiária de interesse social em São Paulo. Tese de doutorado, FFLCH/USP, 2012. 
. Crise urbana: a expropriação extrema dos citadinos nas políticas

de espaço. In: Grupo de Estudos Urbanos, Revista Cidades. Vol. 11, n. 19, 2014.

- Produção contraditória do espaço urbano e resistências. In:

CARLOS, Ana Fani A. (org.). Crise urbana. São Paulo: Contexto, 2015.

. Das ações de resistência urbana à consciência da expropriação. In:

CARLOS, Ana Fani A.; ALVEZ, Glória; PADUA, Rafael F. (orgs.). Justiça espacial e o direito à cidade. São Paulo: Contexto, 2017.

RODRIGUES, Arlete Moysés. Moradia nas Cidades Brasileiras. São Paulo: Contexto, 2003.

SAMPAIO, Renata A. A violência do processo de urbanização. In: CARLOS, Ana Fani A. (org.). Crise urbana. São Paulo: Contexto, 2015. 